University of Nebraska - Lincoln

DigitalCommons@University of Nebraska - Lincoln

Biological Systems Engineering: Papers and

Publications

Biological Systems Engineering

1899

\title{
The Homemade Windmills of Nebraska
}

Erwin Hinckley Barbour

University of Nebraska

Follow this and additional works at: https://digitalcommons.unl.edu/biosysengfacpub

Barbour, Erwin Hinckley, "The Homemade Windmills of Nebraska" (1899). Biological Systems Engineering: Papers and Publications. 296.

https://digitalcommons.unl.edu/biosysengfacpub/296

This Article is brought to you for free and open access by the Biological Systems Engineering at DigitalCommons@University of Nebraska - Lincoln. It has been accepted for inclusion in Biological Systems Engineering: Papers and Publications by an authorized administrator of DigitalCommons@University of Nebraska Lincoln. 


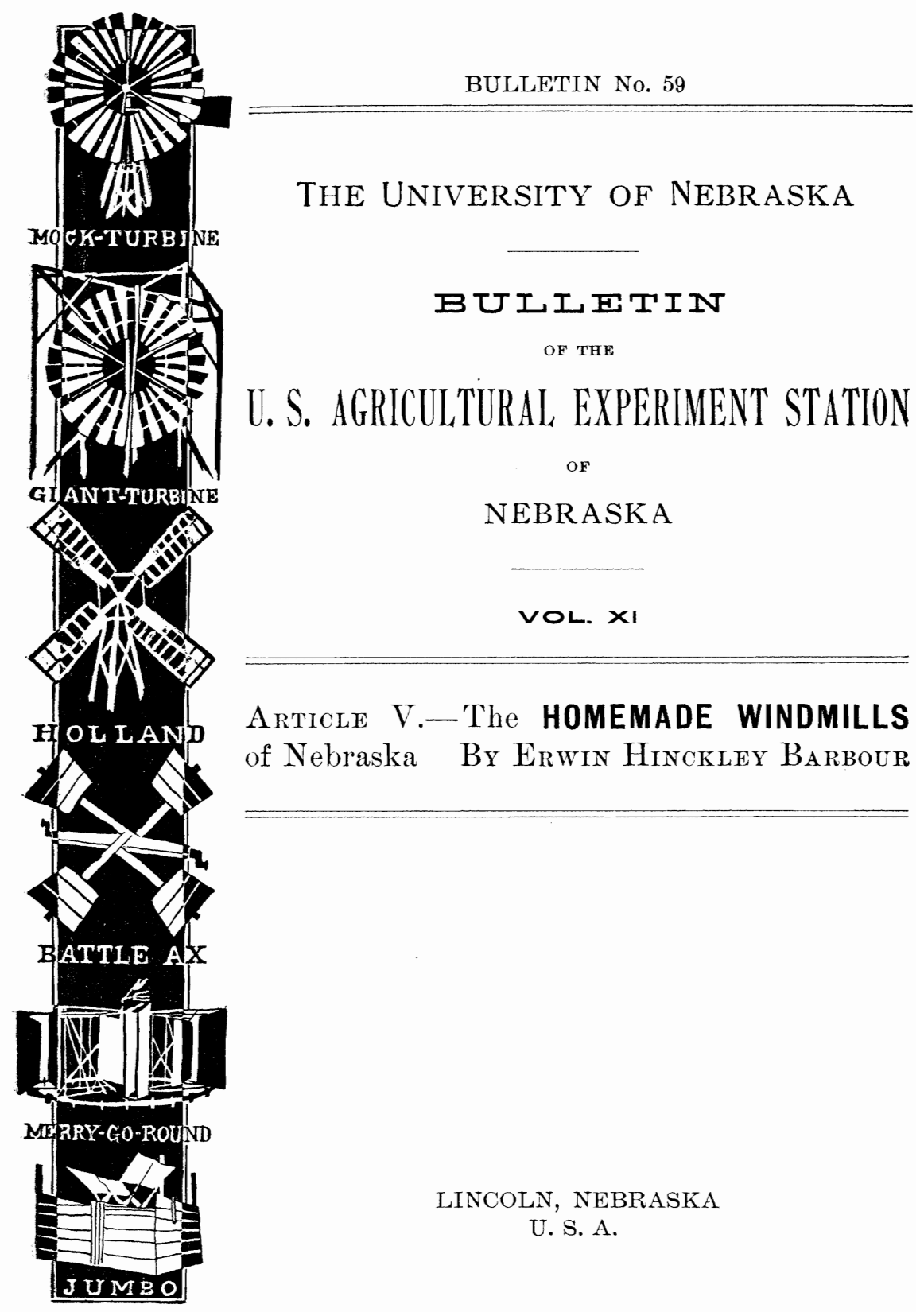




\section{U. S. AGRICULTURAL EXPERIMENT STATION}

OF

NEBRASKA

THE GOVERNING BOARD

(THE REGENTS OF THE UNIVERSITY)

C. H. MORRILL President Lincoln

CHAS. WESTON Hay Springs

H. L. GOOLD Ogallala

THOS. RAWLINGS Wakefield

E. v. FORELL Kearney

GEO. F. KENOWER Wisner

THE STATION OFFICERS

GEO. E. MACLEAN PH. D. LL. D. Director

J. STUART DALES M. PH. Treasurer

WM. W. MARSHALL Executive Clerk

\section{THE WORKING STAFF}

Hudson H. Nicholson M. A. Chemist Charles E. Bessey Ph. D. Botanist LAWRENCE BRUNER B. Sc. Entomologist Erwin H. Barbocr Ph. D. Geologist

A. T. Peters D. V. M. Animal Pathologist

G. D. SWEZEY M. A. Meteorologist

T. L. Lyon B. S. A. Agriculturist

O. V. P. Stout C. E. Irrigation-Engineer

G. A. Loveland B. Sc. U. S. Weather Bureau

R. A. EMERson B. Sc. Horticulturist

W. D. HunTER M. A. Assistant Entomologist

R. S. Hiltiner M. A. Assistant Chemist

Vergil C. Barber A. B. Assistant Animal Pathologist

WM. H. Tuck Lab. Asst. in Animal Pathology

S. W. PERIN Foreman of Farm 


\section{CONTENTS}

Page

Istroduction ...................... 5

Classification of Homemade Windmills............ 10

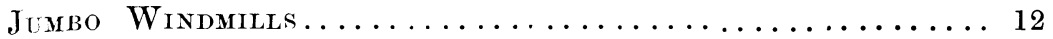

Baby Jumbos ....................... 13

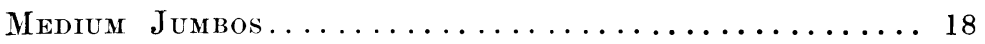

Giant Jumbos........................ 24

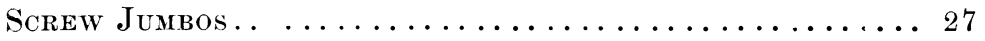

Construction of Jumbo Windmills............ 28

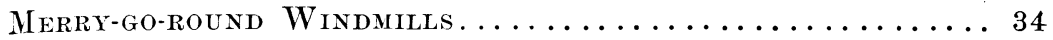

Construction of Merry-go-round Windmills......... 36

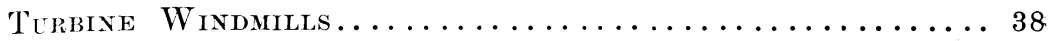

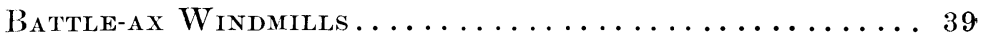

Dutch Windmills in Nebraska ............. 53

Towerless Turbines................... 56

Stationary Turbines.................. 58

Vaneless Automatic Turbines.............. 64

A Giant Turbine.................... 66

Mock Turbines..................... 67

Reconstructed Turbines.................. 70

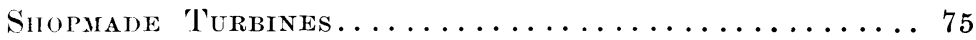

Original Uses for Shopmade Windmilla........... 76

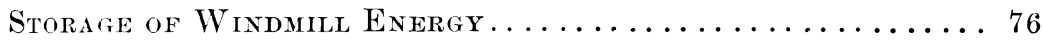

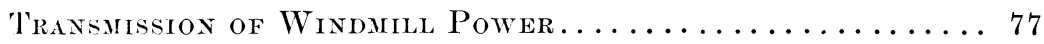

Other Water Lifters................... 78 


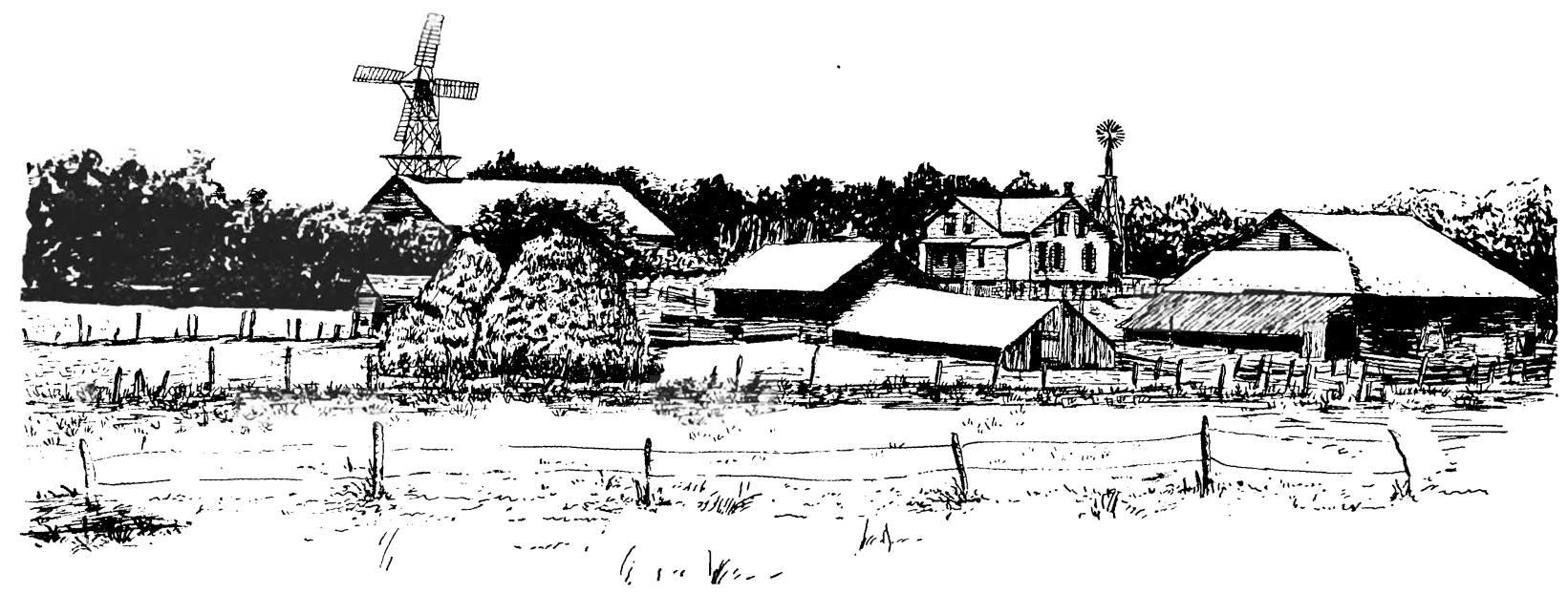

A GENERAL VIEW OF THE PROPERTY OF MR. AUGUST PRINZ. NEAR CHALCO, NEBRASKA.

Introduced to show the surroundings of the men who build the homemade windmills of Nebraska. See Fig. 54. 


\section{The Homemade Windmills of Nebraska}

\section{By Erwin Hinckley Barbour}

\section{A PRELIMINARY REPORT}

While engaged upon the preparation of a paper treating of the relations of the homemade windmills of our State to its agriculture, the writer finds such great and increasing demand for some short and immediate report on the subject, that he is led at the request of correspondents to publish the following brief preliminary paper, awaiting the time when a systematic and formal report may be possible.

It is not the writer's object or intention to offer our citizens advice - for he is the one who is under instruction-but rather to bring together views of a number of mills, and to compile facts about their uses, construction, cost, and durability, which may be of possible use to prospective builders, and by which they may be enabled to select the design which seems to them least faulty, or best suited to their individual wants.

In the judgment of the writer, whose seven years of residence has enabled him to visit nearly every corner of the State, this is an important agricultural movement, and is worthy of much fuller treatment than is possible within the scope of this paper.

The importance of this movement, inaugurated by our inventive farmers, is made manifest in that many acres of garden truck, fruit land, and even farm land are irrigated; that stock is supplied with water; that ranchmen and sheep herders are benefited; that dairy products are increased and improved; and that the comfort of the village and the rural home is often enhanced.

The merit of homemade mills has enjoyed such prompt recognition that they are going up daily. Not to the detriment, we are happy to say, of those important adjuncts to the farm, the shopmade mills, but in addition to them.

In a given community, the man who puts up the first mill generally furnishes the model for the rest of the community. BLLL. 59 AGR. EXP. STAATION OF NEBR. VOL. XI. ART. v. 
Hence it seems the more desirable that good models should be at hand. The better models are often of quite as easy construction and no more expensive than the poorer, and their efficiency considerably greater. It is advantageous to have good models to copy, and the next best thing to the actual model is a good simple drawing. This is the first object of this paper on our homemade windmills; it aims to supply cuts illustrating all sorts of windmills, as found in this State. These in a certain way will serve as models, and may guide citizens to this extent, that they may benefit by the experiences of others without necessarily compromising their own individuality and personality. They can build the mill which they have conceived of, and do it in their own way, and yet they may benefit somewhat by what others have done before in the same line.

The present paper will make little attempt to do more than sketch in pen and ink our most typical mills, accompanying the same with brief descriptions. This will be followed at once with a paper similar in character, but containing in addition drawings to show the construction of each mill; to be followed as soon as means and space will allow with a much larger paper, illustrated by half tone engravings from actual photographs, with constructional plans, and with data as to efficiency, etc.

Those who have had little chance to observe for themselves can scarcely be brought to realize the great number of homemade mills, and the wide territory which they cover. But to the writer's knowledge they extend in almost unbroken succession from Omaha to Denver, and from South Dakota through Nebraska, Kansas, and Oklahoma; our own State being plainly the center of the movement. The writer has gone by rail over the various roads; has driven by team; has employed-at his own expense-students to drive several times across the State in various directions. In this way as will be very plainly seen, a large number of places have been visited, and a very fair survey of the windmill has been made, and from the knowledge obtained it may be said that the Platte valley from Omaha to Denver seems to be the very backbone of the homemade mill, its ribs extending out on all sides along the lesser river courses of the 
State. They are found in : alleys rather than on table lands, for the reason perhaps that there the water is shallower and more easily raised by mills of low efficiency.

The towns in the Platte valley are each of them oftentimes windmill centers about which are often clustered twenty to thirty or more mills of homemade design. Columbus, Grand Island, Kearney, Overton, Cozad, Lexington, Gothenburg, Ogalalla, and intermediate and adjacent towns are, in a way, each a center for homemade mills as well as other forms of water lifters. Those at Grand Island are especially numerous as may be better appreciated from the fact that we were unable to see them all after having driven for four days among the excellent mills designed and built by the German farmers living around this growing city.

As said before, the first mill sets the style in mills for a community. Accordingly in certain German settlements we find the old-fashioned Holland mills, more or less modified, until they little resemble the original or mother mill.

In other communities especially in eastern Nebraska, the Jumbo or "go-devil" mill is the prevailing form. In central Nebraska, and well to the west, the type of homemade mill known as the Battle-ax is plainly the prevailing type, and it is a first rate form of mill. Besides there are a variety of other designs to be described later in a more specific manner.

As to the usefulness, cheapness, and durability of such homemade productions it may be said that a good basis for a fair judgment in this matter is found in the fact that the designers and projectors speak in high praise of their mills. This would be otherwise if the mills were not satisfactory in each of the above respects. Some are so hearty in their praise of the homemade mill that the author by contact comes naturally to speak with equal confidence of these mills as important agricultural aids. Some have looked upon them with distrust, believing that any citizens too poor to put up the regular shopmade mill, were on the face of it shiftless, unreliable, and undesirable citizens. As a fact it turns out that just the reverse of this holds true.

The builders of homemade mills in Nebraska are generally the wealthier and more progressive among the older and better 
established farmers; or else younger men, just making a start, but with good credit and as fair promise as their older brothers; or else market gardeners, ranchmen, cattlemen, sheep herders or others.

This much is certain, that they are put up by our best citizens, and not by the worst, and by a stable, and not by a roving, unsettled, or shiftless class.

In substantiation of this the writer will occasionally insert views to show the general surroundings of the men who design and build their own windmills. Later this will be more fully shown by better cuts. The very fact that a farmer is disposed or is able to design and construct, is evidence of good citizenship. Such men are the ones whose gates, fences, outbuildings, farm machinery, and in fact the whole place, are each and all in good repair. The writer believes this to be a fair, and not an exaggerated estimate of these men.

And here he must make haste to correct a statement of his own, published before investigation had progressed far enough to make judgment wholly reliable. It was a mistake, as the writer has since learned, to attribute to "the past few years of stringency and drought the remarkable growth of homemade windmills in Nebraska." It is true that many market gardeners during that trying time, did build mills, and thus save their crops, but it turns out that most of our homemade mills are not built out of necessity, but rather as luxuries or conveniences by men who have means enough to own regular mills, and in addition a few homemade mills to do certain duties in certain places, say in pumping stock water in this pasture or that. Some large ranches report five or six such mills in operation pumping water for their stock. Smaller enterprises demand fewer mills.

While some beginners use the homemade mill for the irrigation of the garden and for supplying the house, others make luxuries of them rather than necessities in this sense, that they put them to work in various ways to save hand labor, such as running the grindstone, the churn, the feed grinder, corn sheller, the wood saw, and other farm machinery.

As to the cost of such mills it may be stated in a general way 
that they are inexpensive, and that their cost is not as great as their usefulness. In dollars and cents the average mill will not fall far from four to five dollars, not including labor. Labor, it is found, is contributed freely to such work, at times when more important work is practically at a standstill. Were it otherwise the undertaking would be of doubtful merit.

Unless such mills can be put up at odd times, and made out of material at hand, by which is meant old lumber, poles, and hardware common to every farm, they are better left unbuilt, for they defeat the very ends for which such mills exist. Let them be built cheaply, or not at all.

Some builders, by a display of superior management, erect excellent mills, sometimes without cost, at other times at a merely nominal expense of one or two dollars for extra lumber and hardware. We have seen mills doing good service on market gardens which cost but one dollar and a half; we have seen them on large farms where each mill was pumping water for the cattle on each quarter section, and yet such mills did not cost more than a dollar and seventy-five cents. This is getting good service at a very small cost. From this up there is every gradation in price to mills costing one hundred and fifty dollars, with an efficiency of eight horse power, and capable of grinding food for the stock at the rate of two hundred to three hundred bushels of grain per day, according to the wind. This last is the most expensive mill known as yet in the State. However the work it performs seems to be commensurate with its cost. Similar mills costing fifty dollars ground one hundred bushels per day.

The owners of these mills were farmers of wealth, and had it been possible to get a shopmade mill heavy enough to do the same work they would have preferred to buy, and thus avoid the care of planning, and designing, and building their own. This offers another justification for the homemade mill.

Many farmers turn old farm machinery to admirable account in windmill construction; in this way they secure the best of turned bearings, without cost, and, at a small outlay of capital or time, procure a good, cheap, and lasting mill. 


\section{A CLASSIFICATION OF HOMEMADE MILLS}

The study of our homemade mills has progressed to a poir where it seems possible to offer a sort of classification.

\section{A Scheme of Classification Covering all the Main Types of Homemade Mills Known at Present in the State}

7. $\square$ Shopmade 'Turbines

See page $7 \tilde{5}$

6. Reconstructed Turbines See page 70

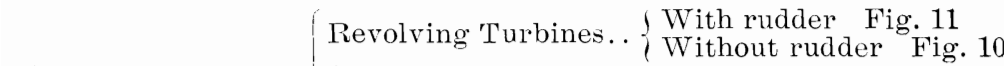

5. Mock Turbines.. \{ Set Turbines

See page 67

Giant Turbines Fig. 9

4. Holland mills.... $\begin{aligned} & \text { With eight fans } \\ & \text { Wee page } 53 \\ & \text { With six fans } \\ & \text { With four fans Fig. } 8\end{aligned}$

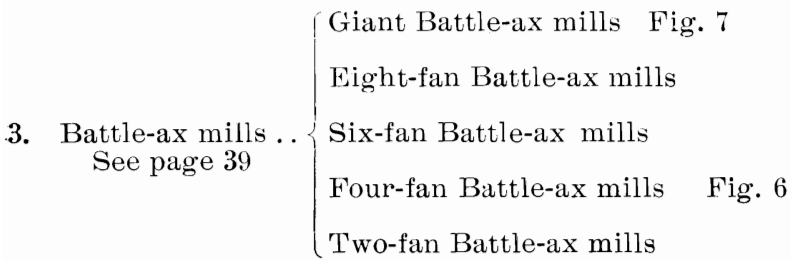

2. $\underset{\text { See page } 34}{\text { See pagrounds }}\left\{\begin{array}{l}\text { Unmounted Fig. } 5 \\ \text { Mounted Fig. } 4\end{array}\right.$

1. Jumbos........ See page $12^{\text {Giant Jumbos..... }}\left\{\begin{array}{l}\text { With screw fans Fig. } 3 \\ \text { With eight fans } \\ \text { With six fans } \\ \text { Medium Jumbos..... With four fans Fig. } 2 \\ \text { Baby Jumbos Fig. } 1\end{array}\right.$ 

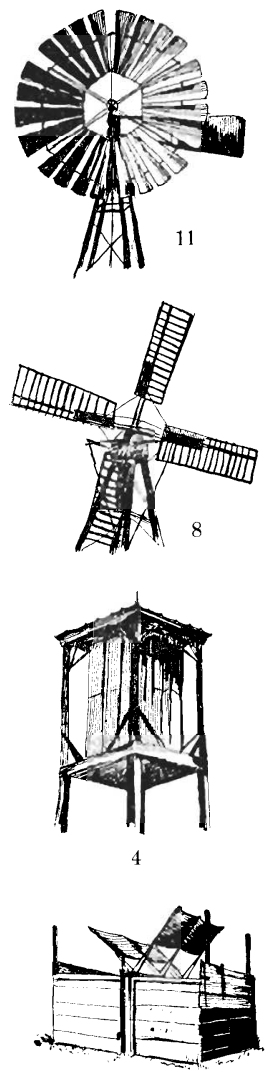

2

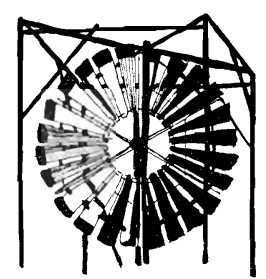

9
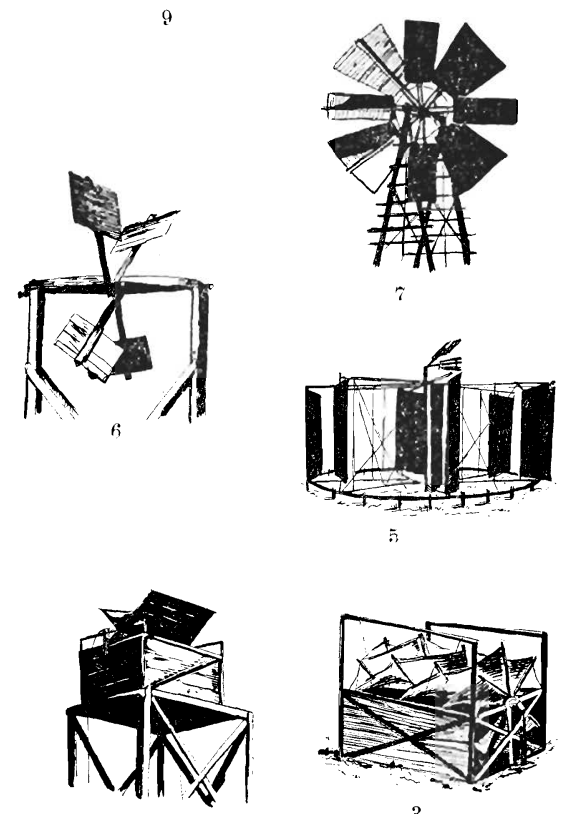

1
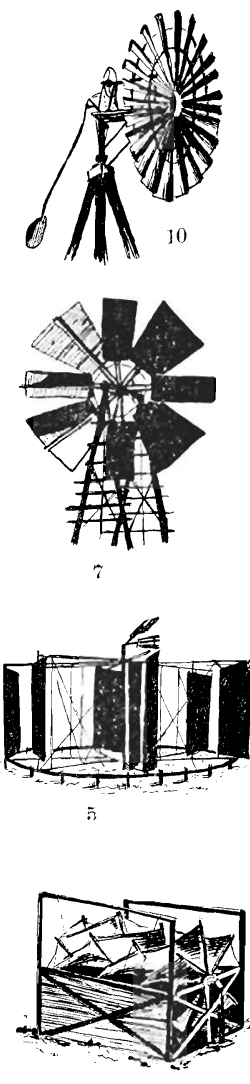

No. 1. Baby Jumbo Windmill.

No. 2. Ordinary Jumbo.

No. 3. Screw Jumbo.

No. 4. Merry-go-round, mounted.

No. 5. Giant Merry-go-round.

No. 6. Battle-ax Windmill.
No. 7. Giant Battle-ax.

No. 8. Holland Mill.

No. 9. Giant Turbine Windmill.

No. 10. Mock Turbine (rudderless).

No. 11. Mock Turbine (with rudder).

Beginning with the lowest and least efficient mills, and running up the scale to those of higher efficiency and increasing specialization, we have first the Jumbo family, including Baby Jumbos, Medium and Giant Jumbos, and Screw Jumbos; second, Merry-go-round mills, including the mounted and unmounted forms; third, Battle-ax mills, including two-fan, four-fan, sixfan and eight-fan Battle-axes, and Giant Battle-ax mills; fourth, 
Holland or Dutch mills, small and large; fifth, Mock Turbines, which closely resemble the shopmade mills, including those with four, six, eight, and many fans, and the Giant Turbines; sixth, reconstructed Turbines, with and without rudder. At the head of this series should come a seventh group, the regular shopmade mill.

\section{THE JUMBO WINDMILL}

The Jumbo mill, or Go-devil as some call it, is very like an old-fashioned overshot waterwheel. It is simply a sort of overshot windwheel.

We have taken the liberty of putting it in the lowest group of mills, where it probably belongs, although in talking with their owners, it is plain that they defend these mills, and would put them in a higher class. All of which speaks well for this simple and useful mill. However as a matter of fact, they are probably the least efficient type.

This much must be said, that they lend themselves readily to construction, being very simple in design. Furthermore almost any kind of material may enter into their make-up, so they are economical. We have seen old lumber, lath, shingles, split rails, old packing boxes, barrel staves, coffee sacks, and even the tin from old tin roofs pressed into service in the construction of these mills. We even found the tin can doing service in this capacity, for one farmer living near a small town found hundreds of old tomato cans in the dump near his place. Raking these into a heap, and covering the same with straw which was burned so as to unsolder the tops, bottoms, and sides of the cans, this farmer found himself with several hundred pieces of tin which he nailed to the loose sides of his Jumbo box. This was counted an interesting case, and others might be cited, but this is quite enough to verify the statement that these mills can be constructed largely of old or even of waste material such as is common to almost any farm. If the Jumbo cannot be built cheaply, and by one's own labor, it were better not built at all. This is not literally true, for any mill is better than no mill, but some other form of mill could be chosen to advantage. 
The Jumbo can be used advantageously, as is illustrated by its practical operation all over the State, to pump water for the house, or for the stock, or for the irrigation of small patches of orchard or garden. For the irrigation of large tracts it may not amount to much, but touching this point it may be well to remember that if one small Jumbo can irrigate a small patch, several large Jumbos could irrigate a much larger one.

We have seen the Jumbos varying in size and strength from those at work pumping water for the irrigation of the garden of a town lot up to those which were irrigating ten acres of orchard. If this much is already possible, more is to be expected. Several Jumbos, if well built, would do not a little service in field irrigation, especially if the water was first pumped into a storage reservoir, and thence into the furrows. And its usefulness might be still further enhanced by using it steadily during the fall and winter in order to get the ground well soaked.

Some irrigationists in the State purchase their water rights in the fall and winter for the reasons; first, that there are fewer using water at that season and it is cheaper; second, by flushing the fields, fall plowing is made easy; third, by wetting the ground thoroughly at this season, it is considered by many to virtually insure the crop. If the best use is made of the Jumbo the results are not to be despised:

This is not to be construed as a statement that much of agricultural importance is to be expected in this direction, although a great deal seems possible. In point of price our Jumbos range from the baby Jumbos which cost nothing, or at most but a dollar or two, to the medium Jumbo costing four or five dollars, even to the giant Jumbo which costs one hundred dollars and irrigates ten acres of orchard.

The baby Jumbo as the name implies is a very small mill, so small that they at first passed for playthings, but the author finds that they are put to very good account. They are generally mounted upon abandoned towers, or upon buildings, while the large Jumbos are set upon the ground, and securely anchored there; all being so set as to catch to best advantage 
the prevailing wind of the place, which is north and south in Nebraska.

THE GOODRICH JUMBO

The baby Jumbo on the Goodrich farm at Bethany, Nebr., was built in play by Mr. Goodrich's boys and without cost, yet it was put to work to pump water for the stock. It stands upon the abandoned frame work of an old water tower, so its small fans are more exposed to the impact of the wind. Then it is geared back by means of old sprocket wheels and chains taken from a self-binder, in the ratio of two to one, which gives the small mill a mechanical advantage. Its arms are two and one-half feet long and each of the four board fans is about four feet long by two feet wide, thus exposing but about eight square feet to the wind.

This is a showy little mill, and one which has been figured in agricultural papers, and it does its work well enough, considing that it is a toy which cost nothing. However, it is introduced here to show what is possible, rather than to advocate the introduction of this make or this size.

It seems to the writer to contain a rather suggestive and instructive lesson. If boys can add such important helps to the farm in play, what may not be done in earnest, especially if the boys have parental encouragement, and a model to work from. This matter of models is a strong incentive with the writer, who believes that many a boy on the farm can follow out the hints which are here compiled from various builders over the State, and thus add that much to the usefulness and comfort of the parental home.

Even the district school, which is so dear to the American heart that we would fight for it as quickly as for any of our institutions, though often placed in the barest, bleakest spot, might be brought that much closer to every patriotic heart by having a little shade, and possibly a few vines. All of which is rendered possible by the Jumbo or other homemade mills which the boys could build.

If we are so devoted to our great public school system, which we rank in importance above the college and the university, 
because it is the foundation of learning to every home, not to the favored few, then why not show appreciation by giving this "college of the great masses" a little better setting?

In the more humid portions of the State it is an easy matter to start trees in the country school yard. In the more arid portions they must have a little fostering care until well rooted. If no better mill is to be had, one might be built by the older pupils. We have seen many creditable mills built by boys ranging from fourteen to twenty years, and feel that there are great possibilities here.

For a time the Goodrich Jumbo was described as the smallest in the State, and it did not seem possible or practicable to attempt

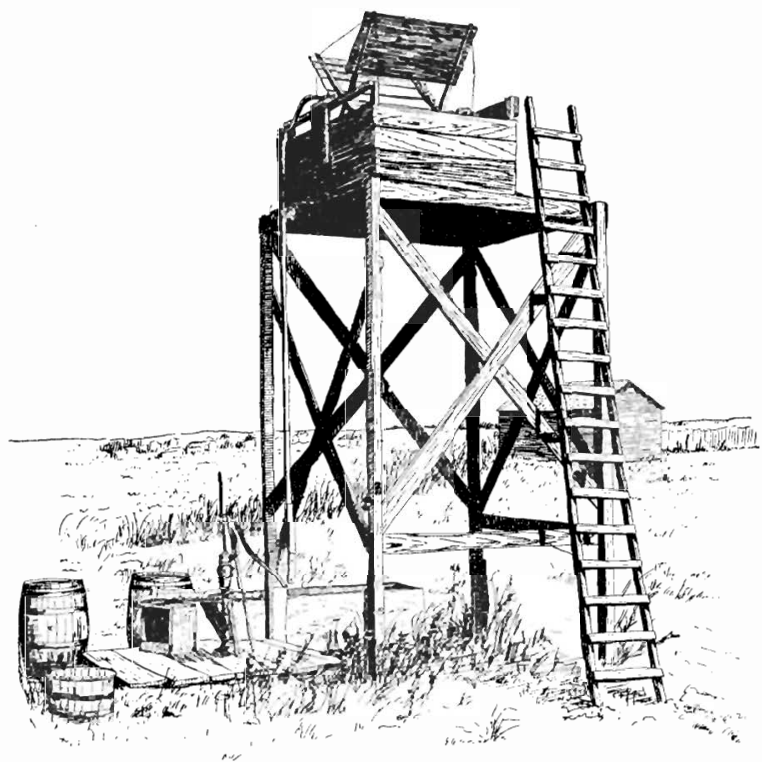

Fla. 1\%. The baby Jumbo designed and built by W. W. Iler. Havelock, Nebraska. It has four fans each three feet long with arms two and one-half feet long attached to an iron axis. It is attached by a sixteen inch crank directly to the pump handle. It is mounted on a sixteen foot tower. This little mill. which cost but $\$ 3 . \% 0$, pumps water for the stock, and for a boarding house with thirty guests. lifting the water from a sixty foot well.

anything smaller. However, in a neighboring town, Havelock, we subsequently found a baby Jumbo built by W. W. Iler, which has fans but three feet long, with arms two and one-half feet long; so the fans are a foot shorter than the foregoing. For 
all that it does considerable work, and we have a practical measure of its efficiency in that it pumps the water for the stock, and for a boarding house, or sort of private hotel having thirty regular guests. What more is to be asked of a mill which cost its owner and builder but three dollars and seventy cents? It has this advantage, that it is set upon a tower sixteen feet high, so catches the wind. In a strong wind this little mill has pumped as much as three or four hundred gallons in forty minutes, lifting it sixty feet: as measured in barrels by the owner. Whether accurately or approximately measured, it is plain that the little mill is doing a big work.

Its real usefulness to the household is borne in the more forcibly when the wind shifts to the east or west, and they are compelled to pump by hand the water necessary for so large a house. Later the true efficiency of this mill will be measured and reported. Other Jumbos in other parts of the State are almost as small, but as far as is now known, this must be reported as the baby of all.

Next in size comes the remarkable Jumbo designed and built by J. L. Brown, owner and proprietor of the Midway Nurseries near Kearney, Nebr. It cost but one dollar and a half, spent for its gaspipe axis, yet it pumped water enough for the successful irrigation of the garden, strawberry patch, and small fruit during the most trying season of drought ever experienced in the State. Without it everything would have been a failure.

The fans and Jumbo box were built almost wholly of the sides and ends of old grocery boxes, thus securing a maximum of usefulness at a minimum of cost.

This mill reverses the ordinary proportions, in that it is narrow and tall. Its proportions are, height ten feet, width three feet. Box three feet wide, nine feet long, six feet high. The pump stood about five or six feet from the mill and was connected with it by a lever in the ratio of five or six to one, which gave it an advantage.

When visited, a fair wind-probably a ten mile wind-was blowing, and it was pumping vigorously, and continued to work with undiminished force after an additional load of one hundred 


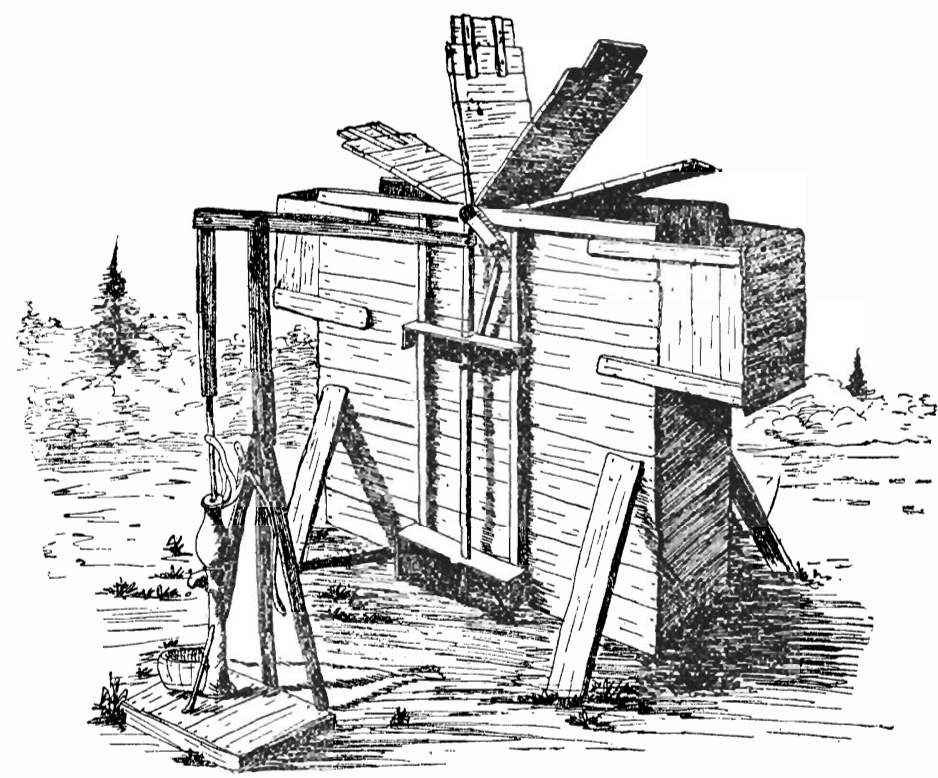

FIG. 13. A remarkable little Jumbo, designed and built by Mr. J. L. Brown, proprietor of the Midway Nurseries, at Kearney, Nebraska. It cost but $\$ 1.50$, yet it pumped suffleient water to irrigate and save the garden truck, the strawberry patch, and the small fruit during the most trying season of drouth ever recorded in the State. Box three feet wide, nine feet long, six feet high Eight fans, three feet wide by four and one-half feet long, supported on a gaspipe axis.

and fifty pounds was added to the pump rod. It was not overloaded by more than two hundred pounds or more. Means were not at hand for the measurement of its true efficiency, which Mr. Brown estimated for us by saying that the profits from that small mill, during the three distressing seasons of drought probably exceeded that of the place.

Many others have made similar statements. This is not meant as a great claim for such mills, but this much holds, that when these small sums are the total of the balance sheet for the year, they are appreciably large. The mill is an important aid at all times, sometimes the mainstay of the place.

Many such mills are found in the outskirts of small towns. For the farm and for the stock a larger size is desirable; which brings us to the ordinary or medium sized mills, a good example of which is that of Dr. Boardman in the edge of Overton. 


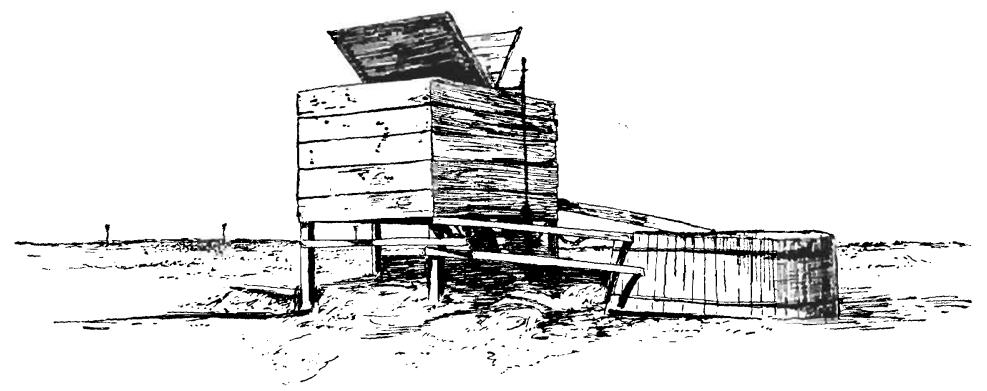

FIG. 14. The Jumbo windmill of Dr. E. O. Boardman, Overton, Nebraska. Built by a carpenter and blacksmith out of new material at a cost of $\$ 8.00$. Iron axle. Fans five by six feet. Jumbo box eight by twelve, by six feet high. Mounted on posts. Pumps water for one hundred head of cattle from an eighteen foot well.

This mill serves our purposes doubly, in that it furnishes exact figures respecting a mill built by carpenter and blacksmith, and out of new lumber. This mill with a Jumbo box six feet by eight feet by twelve feet, supporting four fans on an iron axis, cost just eight dollars. The four fans were each six feet square, boarded up solidly. Had there been six or eight fans with but two or three boards, instead of five or six, the results would have been far better, and it would serve as a model. However, as it is, it serves its owner well, and helps to pump water for one hundred head of cattle. This new mill was built to replace an old one put up three years before and kept in constant use. The owner expects the present mill to pump the water needed by his herd, and expects its term of usefulness to be fully five years. If so, he will be paying for his water service at the rate of about one dollar and a half a year, and the lumber will be in such preservation that by a very little rejuvenation the mill may be made use of again.

Many are convinced that the Jumbo mill is the preferable type, and for all such it ought to be explained that, where there are but four fans, it often happens that they are in surh a position, as they revolve, that but a single fan is struck by the wind at a time, whereas in the case of six fans and eight fans, two, three, or four, may catch the wind at a time, thus giving the mill just that much additional strength. 
There are mechanical reasons for putting one, two, or sometimes three boards well to the extremity of the arms, not to cover them solidly, but rather so as to cover about one-third of the arms. It is necessary to get rid of the dead air-that is the air which has struck the fans and lost its energy - and it is probable that two boards will serve one's purposes better than four, and at the same time save just that much outlay. A mill with proportions as above, but with six fans, and with two or at most three one-foot boards, will do good service pumping for stock.

A mill of about this size, but much more carefully built, was found doing good service in watering a six acre patch of

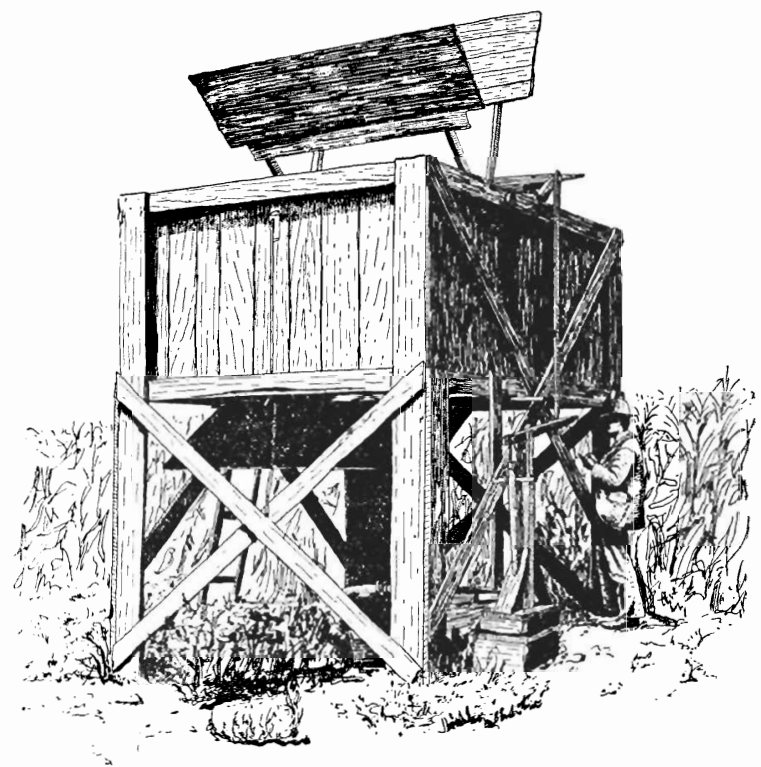

FIG. 15. A six fan Jumbo windmill on the farm of W. W. Goodrich, Bethany, Nebraska, used in watering a six acre patch of eggplants for the Lincoln market. The fans are each nine feet long with arms five and one-half feet long. Jumbo box nine by eleven by six feet high, with door below for the escape of dead air. Extra well built. Axis of Damascus steel. Total cost. $\$ 8.00$.

eggplants grown for the Lincoln markets. This was on the farm of W. W. Goodrich, of Bethany. In one respect this mill was unnecessarily well built. All mills ought to be equally well built, bolted together, anchored, and braced; but as the builder 
himself says, it is not necessary to have a Damascus steel axis with turned bearings, oil cups, etc. A gaspipe axis, he says, would have served the purpose as well, and would have reduced the cost of his mill from eight dollars to three.

This is a six fan Jumbo, each fan being nine feet long, with a radius or arm, five and one-half long, the whole mounted upon a box nine wide by eleven long, by six feet high. As the fans of a Jumbo revolve rapidly within the Jumbo box, it is believed that there is so little room in a well made box for the escape of the compressed air, that it forms a sort of air cushion, which to a certain extent checks and retards the fans. To overcome this difficulty, Mr. Goodrich has resorted to the simple device of having the bottom of the Jumbo box consist of two doors, hinged in the middle, so that one can be lowered when the wind is from the south, the other when from the north.

This mill furnishes very reliable data as to the cost of mills of this size when put up by home labor. Mr. Goodrich says that this mill could be built at a cost of five dollars-omitting the extra good steel axis - and it is an uncommonly well-built mill, and made of good lumber, much of it new. The writer takes this as a fair and correct statement of what the average mill of this size and quality ought to cost, although it is a dollar and a fraction more than that of the estimated average, as figured from the reports of various builders. However, it is perfectly apparent that everyone who has a mill of his own make in successful operation is often led unconsciously to put it in as presentable a light as possible, and so minimize the cost. And, on the other hand, he finds the mill so useful and satisfactory, and the whole family stand in such friendly relations to the new labor-saving acquisition, that they very naturally and honestly exaggerate its efficiency, some even believing and insisting that their mediumsized Jumbos pump more water than the steel mill.

Judging from a number of mills seen in actual operation irrigating garden truck, the above excellent mill is a little too small. The two or three which follow are more nearly the average size advocated by market gardeners.

At Cozad we found a number of homemade mills of various pat- 
terns, and took especial interest in the Jumbo of Mr. M. L. Olson, used for irrigating a small market garden, and a patch of small fruit. This Jumbo was well proportioned and well built, and its action showed that it was surprisingly sensitive to light winds. The box, which was about nine feet wide by thirteen long, by six

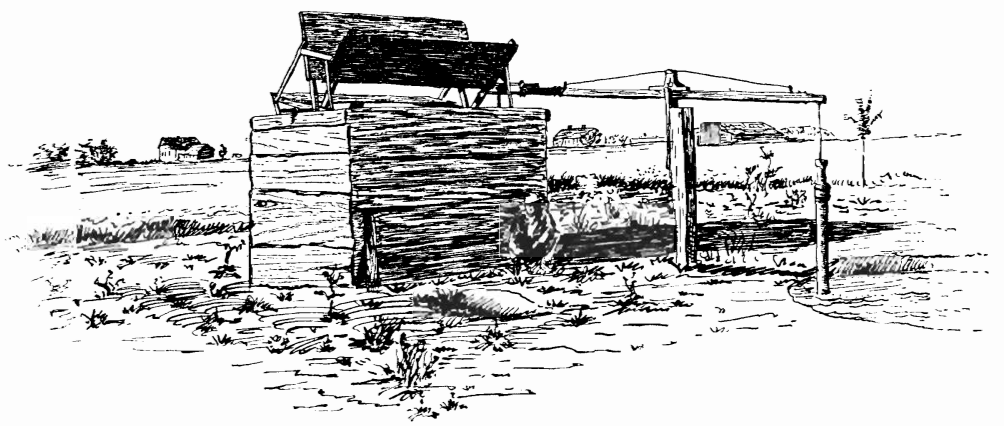

FIG. 16. The six fan Jumbo windmill built by Mr. M. L, Olson, Cozad, Nebraska. Jumbo box about nine feet wide, thirteen feet long, by six feet high. Used for irrigating a small market garden.

high, carried six fans having a radius of six feet and a length of eight feet, mounted upon a one inch iron axis, which ran in metal bearings, with oil cups from old machinery. This axis was turned at one end into a crank twelve inches long, giving a stroke of two feet, and this was connected to the pump rod by a well braced walking beam some fifteen feet in length. The samson post was so set as to divide this lever in a way that gave the crank a slight advantage; the longer arm being nine feet long, and the shorter, six. In such an arrangement it is necessary to let the crank play in a slot in the walking beam, a roller being attached to the crank to reduce friction.

The two mills of the Travis Brothers, Lincoln market gardeners, were observed in practical operation for several months. Their size, rough construction, and numerous crudities, render them nearly typical Jumbos. The two mills watered not far from eight acres, but it must be remembered that the demand for water in the most humid part of the State is less than would be the case farther west. Thus the mills make just that much better showing. In eastern Nebraska, as is so well known, it 


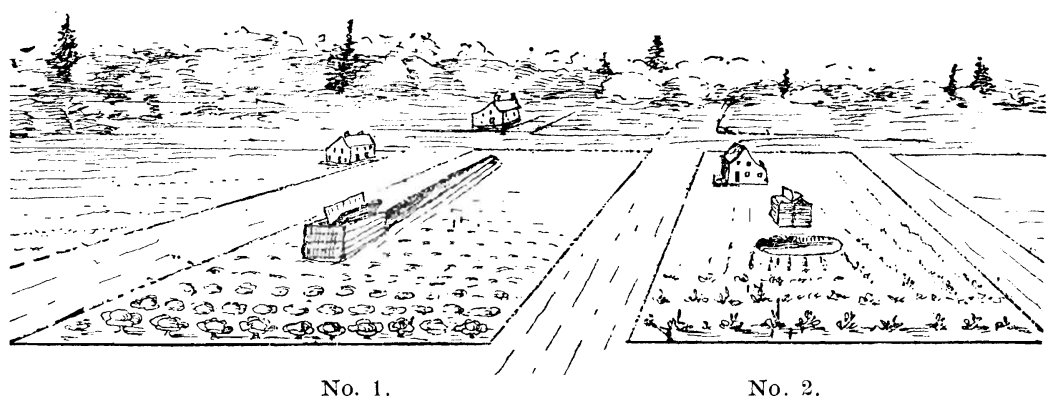

FJG. 17. Market gardens of the Travis Brothers, Lincoln, Nebraska. Mill No. 1 cost $\$ 8.00$, irrigates flve acres. See Fig. 18. No. 2 cost $\$ 11.00$ and irrigates three acres. Reservoir of No. 1 about one hundred and fifty feet long by four wide, by two to three feet deep.

rains at that most propitious time-the growing season-continuing through April, May, June, and July. Accordingly the mill is pressed into service irregularly, to tide the garden truck over a dry week. And indeed, this is the function and the hope of the windmill as related to agriculture. It is not expected that the mill can do the work of irrigation all the time, but rather at the critical time. Let the mill run all the time if need be, but let the water run from the storage reservoir only at the trying time. Managed thus, good returns are to be expected of the windmill in agriculture as well as gardening, but of course in a limited way.

These two mills cost respectively eight and eleven dollars, and if there had been a demand commensurate with the large crop resulting from the use of the two mills, the owners say that nothing more could have been desired.

Mill No. I, which irrigated about five acres, had a box nine feet wide, thirteen feet long, and eight feet high. Each of the four fans were of burlap or coffee sacking, nine feet by four feet. This was stretched upon arms six and one-half feet long. The mill kept the reservoir, which was a unique one, well filled.

The peculiar or original feature of the reservoir lay in the fact that being built where land was valuable and space must be economized, it was built long, slim, and relatively deep. It was one hundred and fifty feet long, four feet wide, and two feet deep, skirting the edge along the highest part of the patch. 


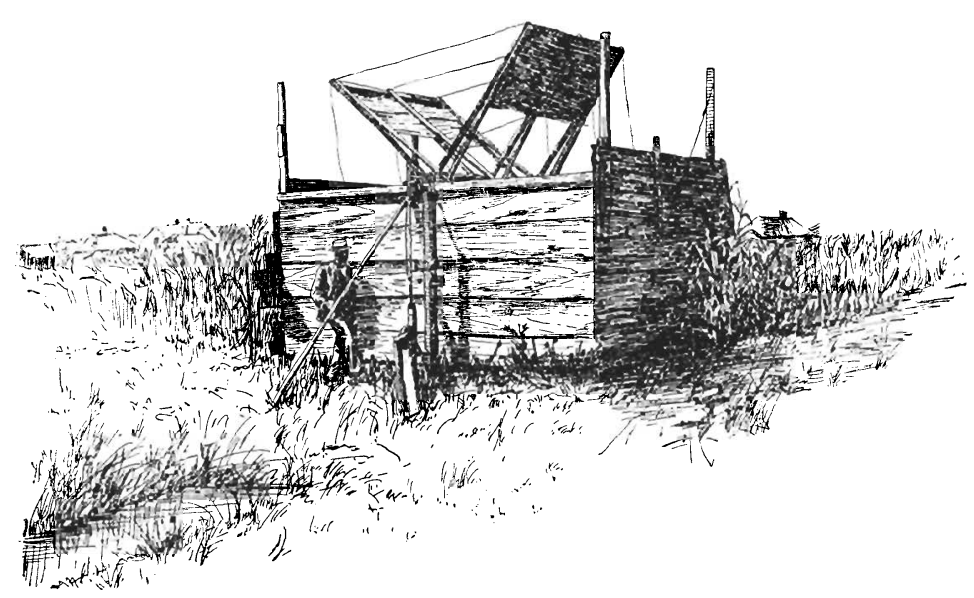

FIG. 18. Mill No. 1 of the Travis Brothers, market gardeners, Lincoln, Nebraska, showing edge of reservoir, one hundred and fifty feet long, four feet wide, two and one-half feet deep. The sails are made of old coffee sacks. The "cut-offs" or wind guards may be seen on either side. These are raised and lowered by pulley and rope. Dimensions nine feet wide, thirteen feet long, thirteen feet high. Cost $\$ 8.00$. Successfully irrigates a five acre garden. See Fig. 17, mill No. 1.

There was enough grade so that the furrows were quickly flooded, and the water cut off and turned into successive rows. In this mill, for the first time thus far, we see an attempt at a regulator for the Jumbo.

Inspection of the cut (Fig. I8) will show an upright support at each of the four corners of the Jumbo box, each support carrying a pulley and cleat; below one can make out a sliding door, which may be raised and lowered so as to cut off more or less, as need be, the force of the wind from the fans, thus regulating the mill to winds of varying velocities. This increases very materially the labor and expense of such a mill, for it is equivalent to doubling the lumber on both of the sides. Besides it is of questionable utility anyway, for most Jumbos are built without any wind guard or cut-off. If such an arrangement is desired it is cheaper and simpler to have the two sides of the box itself adjustable. By raising the side next to the wind the speed of the mill can easily be regulated, or the mill can be stopped altogether. See Fig. I9. Or a still simpler 


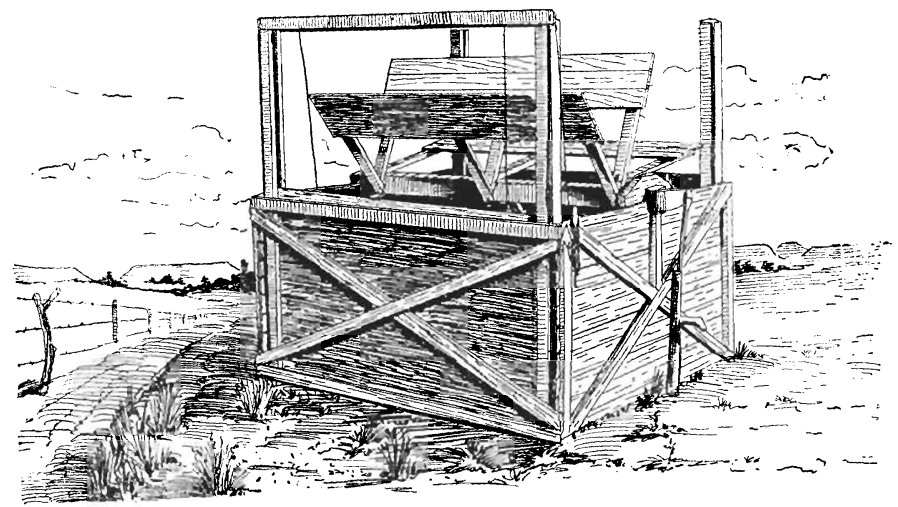

FIG. 19. A model built by the writer showing how the wind guard or cut-off may be the side of the Jumbo box itself, which raises or lowers on the uprights. It would be easier still to hinge it so as to lie flat upon the ground, thus stopping the mill.

method would be to let the sides have hinges at the bottom so that they could easily be let down upon the ground; which would stop the mill.

A much more powerful mill than any of the foregoing was found at the Cushman Park Gardens near Lincoln, owned and built by Mr. C. H. Cushman. It may with propriety be called a giant Jumbo, for its length was nineteen feet, height thirteen feet, breadth thirteen feet. The arrangement of the wind guards

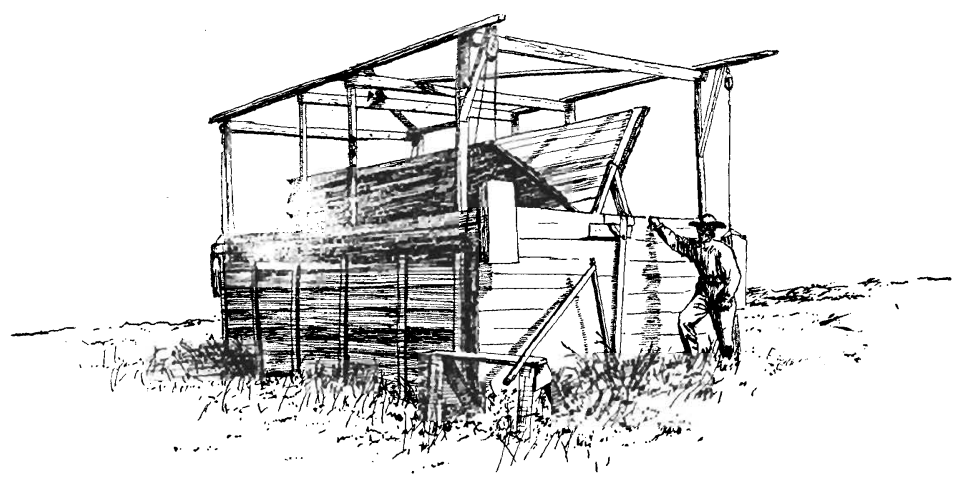

FIG. 20. A large Jumbo mill designed and built by Mr. E. H. Cushman of the Cushman Park Gardens. Size of mill, nineteen feet long, thirteen feet high, thirteen feet broad. Drives two large pumps. Capacity in a moderate wind about one-half barrel a minute. Cost for new materials, $\$ 6.00$. The counterbalanced cut-offs, or wind guards, shown in the cut, make it possible to regulate the mill according to the wind. 
or cut-offs is not wholly unlike that of the foregoing save that they are larger, heavier, and in all respects more unwieldy. Accordingly as the cut will show, they are counterbalanced by heavy weights, which make it possible for one man without mechanical aid to raise and lower them.

The mill easily drives two four-inch pumps one at each end of the axis. It is a four fan mill with eight boards to each fan; accordingly the wooden axis must be subject at all times to heavy strain, thus impairing the strength of the axis, which is still further weakened by being mortised through and through twice at each end for the insertion of the heavy arms. As a result the axis soon breaks at these weakened points, and a good mill is rendered useless. However, it is not necessary to attach the arms in this way, nor is it necessary to have one unsupported axis span nineteen feet, all of which will be discussed in its place.

This powerful mill cost but six dollars.

Mr. Cushman being a man of considerable means and progressive ideas, has a number of regular mills to pump for his. house, stock, and garden, and the result of an experiment with one of these ought to be mentioned. A three-quarter inch stream of water was turned upon the cucumber patch, and during the month of September netted just one hundred dollars in small pickles marketed in Lincoln. Without the artificial watering this crop would have been a total loss. Almost any well-built, homemade mill, though of moderate size ought to easily furnish as much water, and under similar conditions net its owner as fair returns.

Though the Cushman Jumbo was a large and powerful mill, we find a much larger and more powerful one at Columbus, Nebraska. This is truly a giant Jumbo, probably the best known homemade mill in the State; a pioneer mill and one altogether worthy of its reputation. In many ways it may be called a model Jumbo, one to be copied by others. It is well planned and well built, being securely anchored, bolted and crossbraced. It drives two six inch pumps, and irrigates about ten acres of orchard. Like all structures built for strength and permanence, 
it cost considerable money, but the one hundred dollars does not seem disproportionate to the work done.

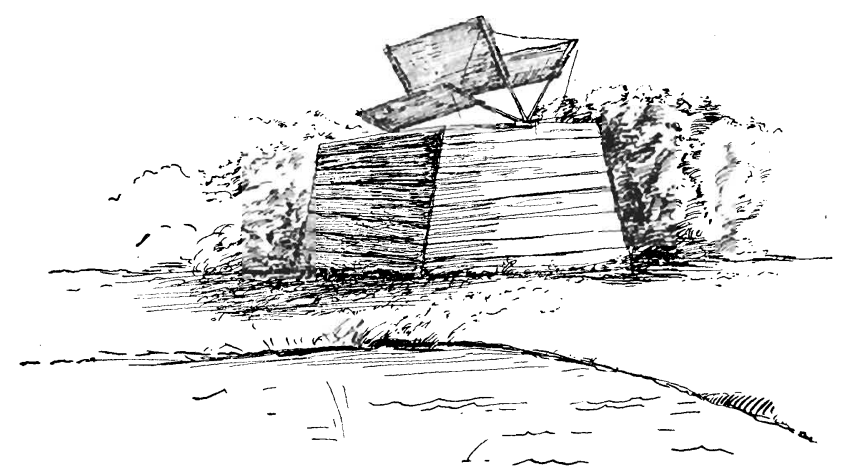

Frg. 21. The giant Jumbo windmill designed and built by Mr. John Tannahill, nurseryman, Columbus, Nebraska. Arms nine feet long, fans sixteen feet by four wide; box sixteen by eighteen by fourteen feet. Drives two six-inch pumps. Used in irrigating ten acres of orchard. Cost $\$ 100$.

Mr. John Tannahill, its owner and projector, found that in his nursery the apple trees, which seemed to be healthy and strong, lost their fruit prematurely, and it is said that he was led to build an experimental mill to see if this was not because of insufficient moisture. It is said that the trees on the ten acres watered by this Jumbo, hold and mature their fruit, and Mr. Tannahill counts the experiment a success, in one way at least. Touching this same point, it may be well to add that as far west as Dawson county, where many claim that fruit culture is impossible, we have seen an orchard of fifteen acres, including apples, pears, peaches, small fruit, and grape vines in flourishing condition, due to irrigation by homemade mills.

The fans of this mill are six in number; are sixteen feet long; and mounted upon arms nine feet long, thus making the diameter of the mill eighteen feet. The accompanying cut will show that care has been taken to leave ample room for the escape of the dead air already mentioned. Mills of this kind are close to the limit beyond which it will hardly pay to increase their size. However the writer has hit upon a plan of arranging Jumbos together in gangs, as described below, see Figs. 31, 32, which 
he hopes will make it possible to construct Jumbos of almost unlimited size, so that this limitation to the usefulness of this type of mill may yet be removed.

There will then remain yet another important limit, namely, the Jumbo is set permanently to face the north and south, that is, in the direction of the ordinary or prevailing wind; accordingly it is literally thrown out of gear when the wind is from the east or west. Some have overcome even this difficulty, and have built universal Jumbos; Jumbos, which though set in a fixed north and south position, run almost equally well from whatever quarter the wind blows.

These are the screw Jumbos of which but two examples are known in the State, one at Trenton, Hitchcock county, built by Mr. C. R. Powers; the other at Ainsworth, Brown county, built independently by Mr. Baldwin. The fans of such mills are of duck stretched along diagonally opposite arms in such a way as to make a veritable screw, whence the name.

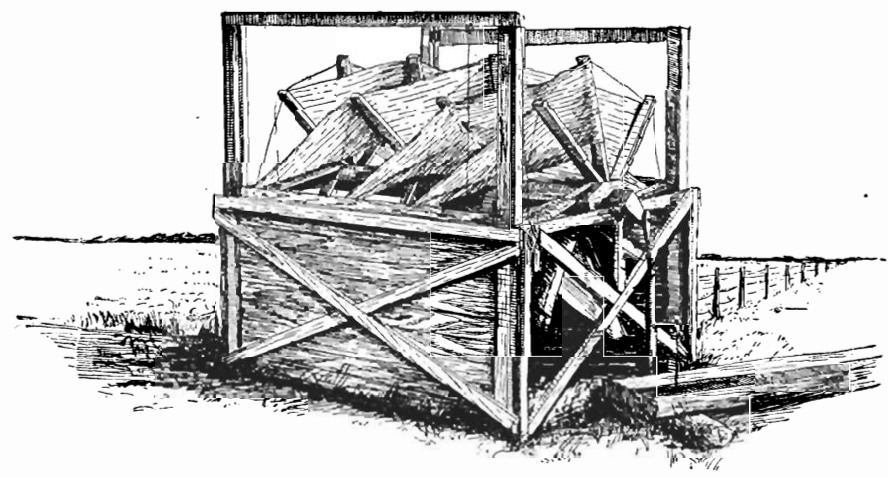

FIG. 22. The Screw Jumbo. This is a rare form, but two examples being known in the State. These mills are almost as efficient in east and west winds as in north and south winds. The wind guard is the side of the windmill box itself, which is raised until air is admitted below as well as above the fans, thus checking or stopping the mill according to the position of the guard. Drawn from a model built by the writer.

The Screw Jumbo Mr. Powers built tas been sold to a neighbor, and a new steel mill set up in its place. He says that the rapid growth of trees around the mill was beginning to cut 
off the wind to such an extent that the mill was disqualified for use. But previously it was a successful and satisfactory mill.

The wheel was eight feet long and ten feet in diameter. The sails were made of heavy muslin, tacked above to a strip of board, below to rope, so they could be furled. The cost of this mill which lifted water from a ninety-six foot well both for house use and for irrigation, was ten dollars.

The Jumbo box was entirely open on the ends. Mr. Powers says that the Screw Jumbo runs more steadily than the ordinary type. Both the builders of these mills speak in praise of their action.

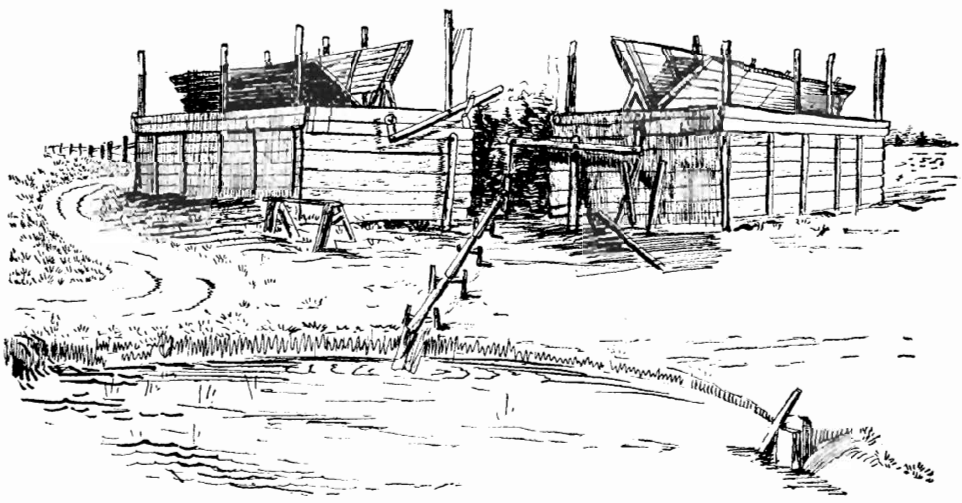

FIG. 23. Sometimes Jumbo windmills are built in pairs, one standing north and south, the other east and west, so as to insure service whatever the direction of the wind.

A model built by the writer shows that the screw Jumbos do indeed run as well as is claimed. Sometimes Jumbos are built in pairs, one standing east and west, the other north and south, thus insuring service whatever the direction of the wind. Fig 23 . 


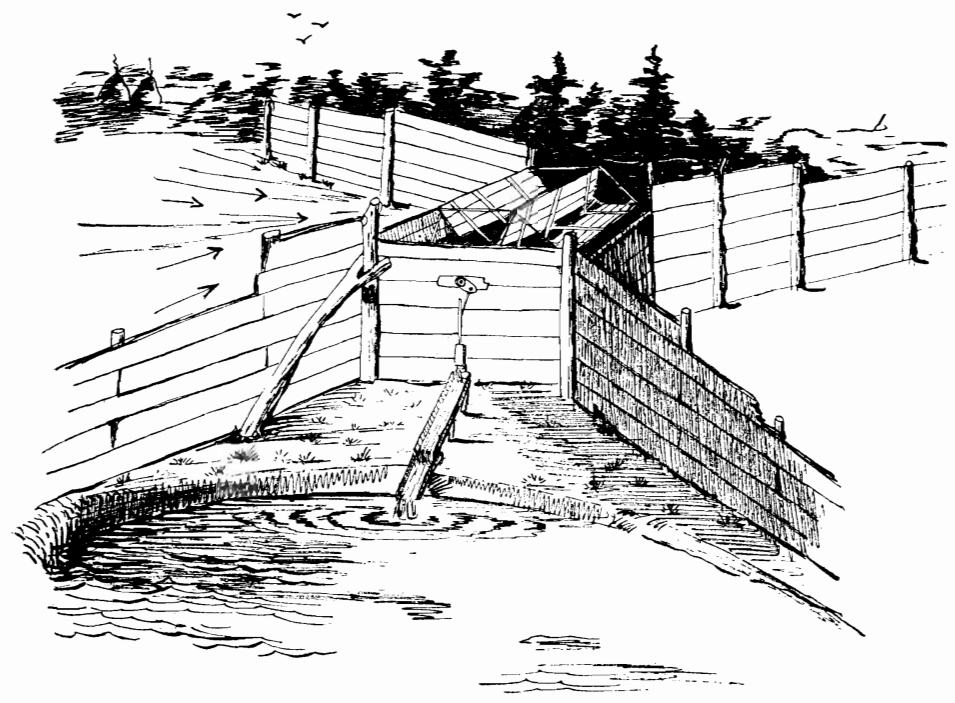

FIG. 24. Jumbo windmills might be set in the corner of corrals, or where high board fences meet. Thus the wind would be that much' better directed against and concentrated. upon the fans.

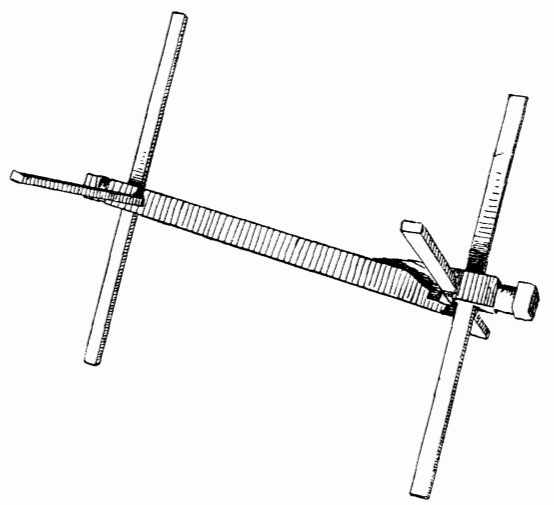

Fig. 25. A figure showing the effect on the axis when it is weakened by mortising. "How not to do it." This is a fruitful, though wholly unwarranted source of windmill destruction. Almost any other method of attaching the arms is better than this. 


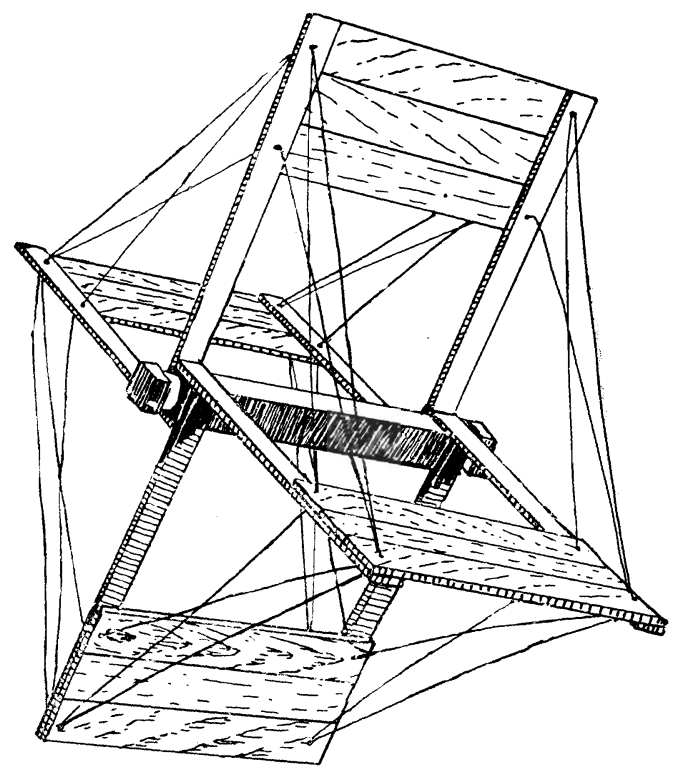

FIG. 26. Plan for the working parts of the Baby Jumbo. Arms three to five feet long; axis four to six feet, to be made of wood or gaspipe as preferred. Fans to be three ito five. feet long, and two to three broad according to the length of the arms. The fans should: cover about one-third of the arms. Six fans are preferable to four.

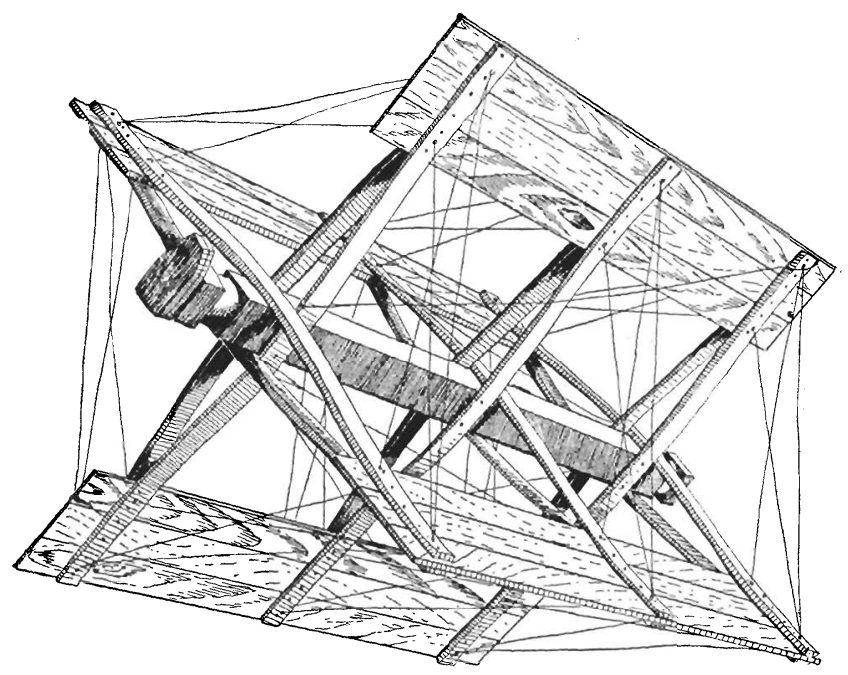

Fig. 27. A figure to show how the arms may be attached to the axis without weakening.

it. The fans may be given great rigidity by cross-bracing with twisted wire.

Drawn from a model built by the writer. 


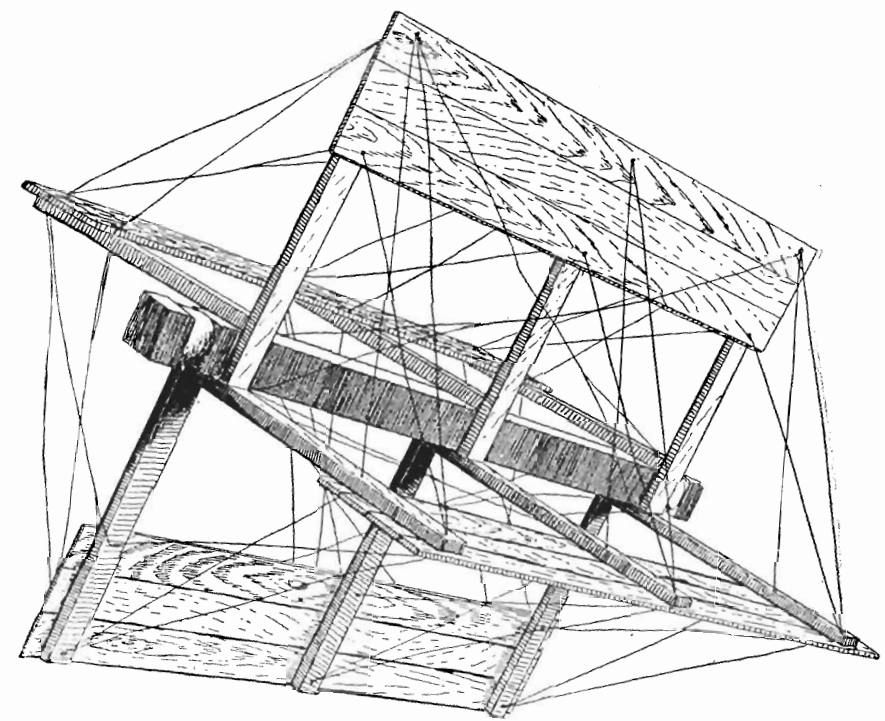

FIG. 28. A method of attaching arms which is at once cheap, strong, and of easy construction. The whole is tied together and cross-braced by twisted fence wire.

Drawn from a model built by the writer.

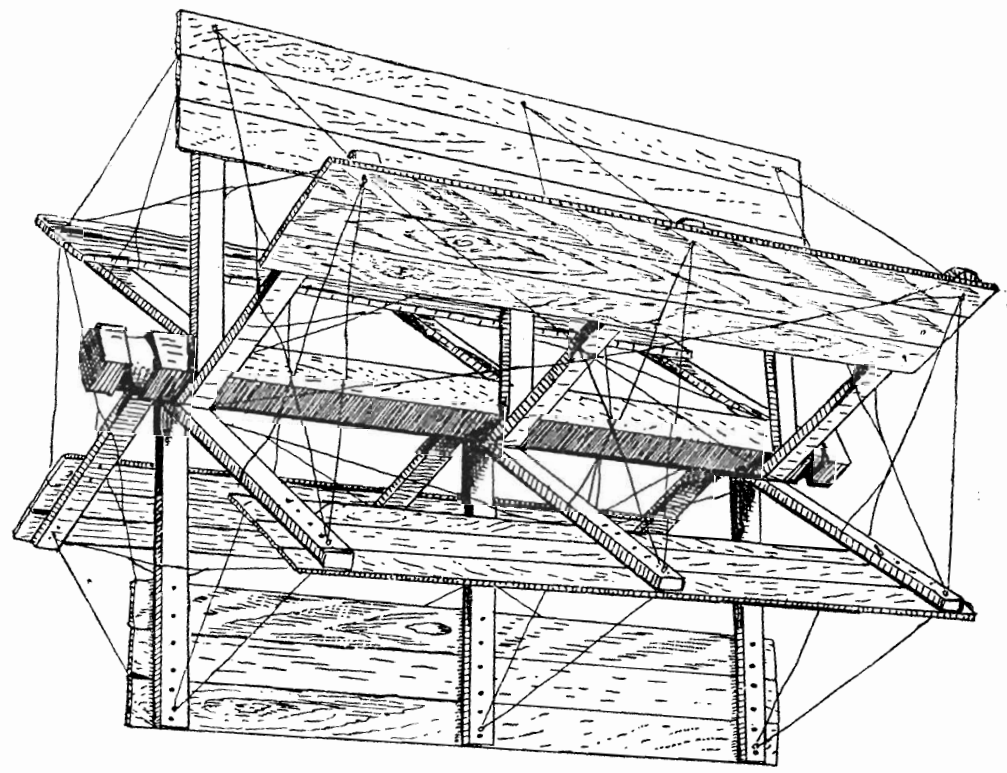

FIG. 29. The construction of a six-fan Jumbo with a wooden axis, cross-braced b5 twisted wire. Size twelve to fourteen feet long; ten to twelve feat in diameter.

Drawn from a model built by the writer. 


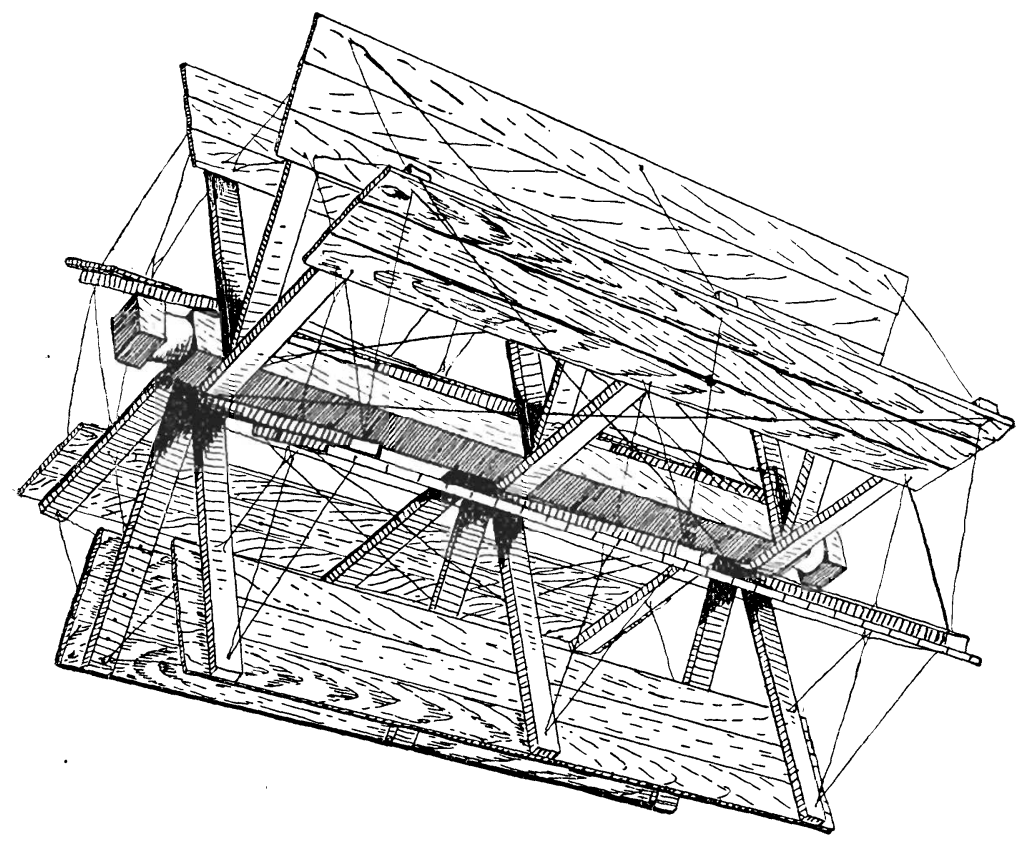

FIG. 30. The construction of an eight-fan Jumbo mill with wooden axis, cross-braced by twisted wire. Six or eight fans are preferable to four fans.

Drawn from a model built by the writer.

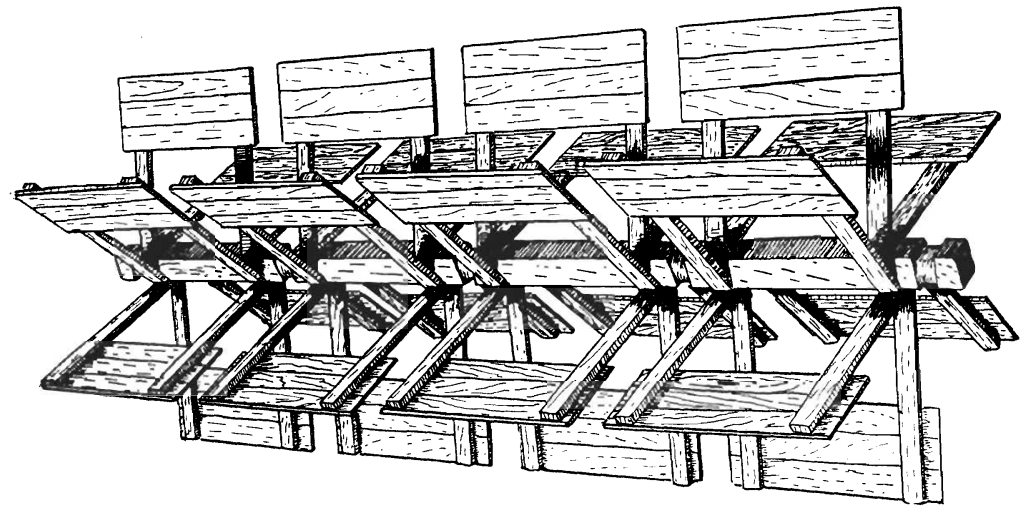

FIG. 31. The construction of gangs of Jumbos as proposed by the writer. Diameter 12 to 14 or more feet; length whatever desired. Thus Jumbos of unlimited size are possible. Each section is designed to be six or eight feet with a support, instead of eighteen feet long, as is a common, and very misguided practice. The writer would suggest two sections for ordinary Jumbos, with a support in the middle; thus the axis would not sag or break so readily, if at all. This is a means of making powerful Jumbos as the writer believes, especially if chain and bucket are used instead of pump. In regions of shallow wells, these might be used for irrigation on a larger scale than is possible with the ordinary Jumbo.

Drawn from a model built under the direction of the writer. 


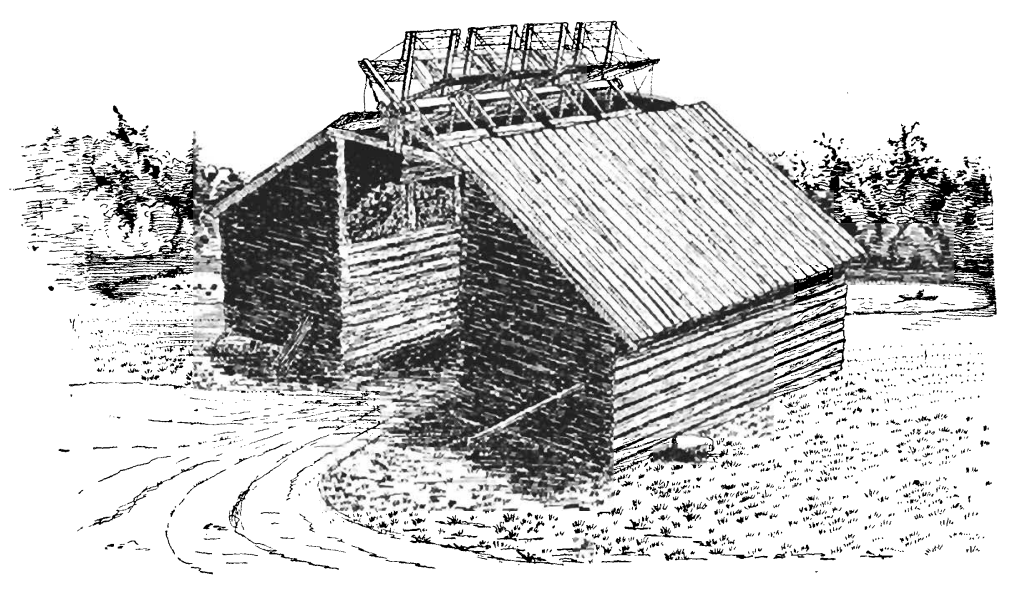

FIG. 32. A sketch to show that an indefinite number of Jumbos may be arranged in a gang, and that corn cribs and sheds may be used for their support, thus reducing the cost merely to the lumber in the fars, arms and axis. Powerful Jumbos may be built in this way at small expense. Diameter twelve to fourteen feet, length of axis twenty-eight to thirty feet, supported at five points. The fans are slowed down by a brake, and are then tied as is a common practice. Cut-offs or wind guards are omitted, it being assumed that the mill is built well enough to breast storms and wind.

Drawn from a model built by the writer.

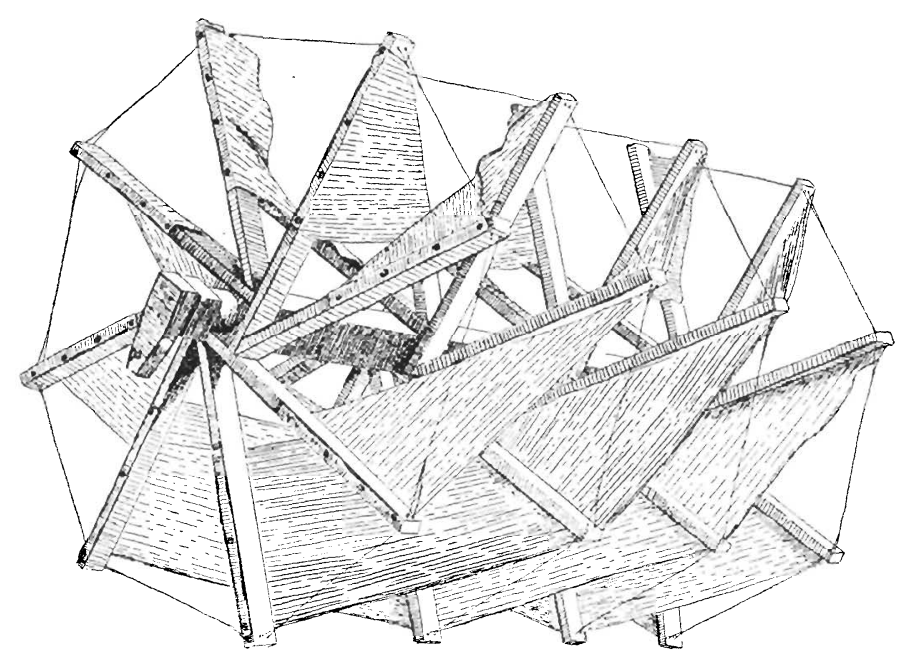

FIG. 33. A figure designed to show the construction of screw Jumbos. The sails are of vanvis, the arms are braced and tied together with twisted wire.

Drawn from a model built by the writer. 


\section{THE MERRY-GO-ROUND MILLS}

In the Merry-go-round mill is found another attempt at theconstruction of mills of unlimited size. However, some of these mills have natural limitations, especially those mounted upon towers. Such mills are of rather complex construction, and are not put up by the farmer, but by a carpenter, and at considerable expense. Mounted as they are upon towers, like the Turbine mill of the shop, they can soon reach a size where the wind can upset them, however well anchored. This has led to the towerless Turbines, which stand low upon the ground, hence are capable of a greater circumference. In the smaller ones which we class with the Merry-go-rounds, the shutter-like fans form a sort of revolving cylinder, which revolves about a central axis. The shutters close on one side and so exclude the air, and open upon the other so as to catch the air, and even the amount is easily regulated by an encircling rope, which allows them to. open much or little, according to the velocity of the wind.

This form of mill though useful once, is now antiquated, and has been replaced by cheaper and better forms, so it needs no.

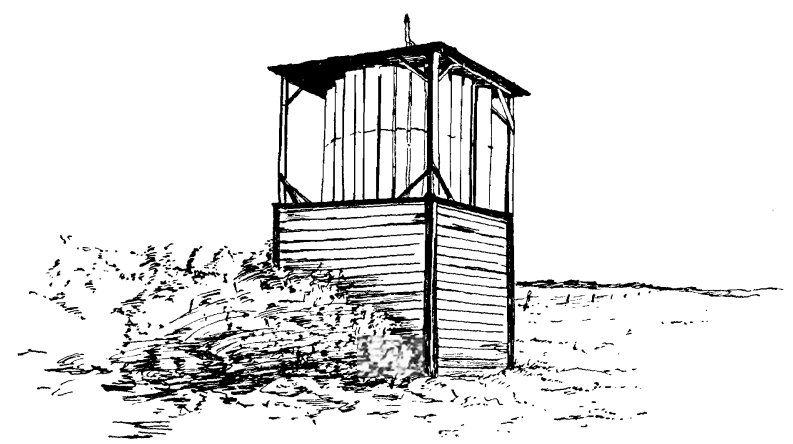

Frg. 34. Windmill of Mr. Henry Joenck, Grand Island, Nebraska. Diameter ten to twelve feet. Fourteen years ago this mill did good service irrigating the garden truck. for the local market. Cost $\$ 100.00$.

further mention here. Several are still to be seen in the vicinity of Lincoln, at Grand Island, Greeley Center, and elsewhere.

They often escape notice from the fact that they are mistaken for water tanks mounted upon high towers. 


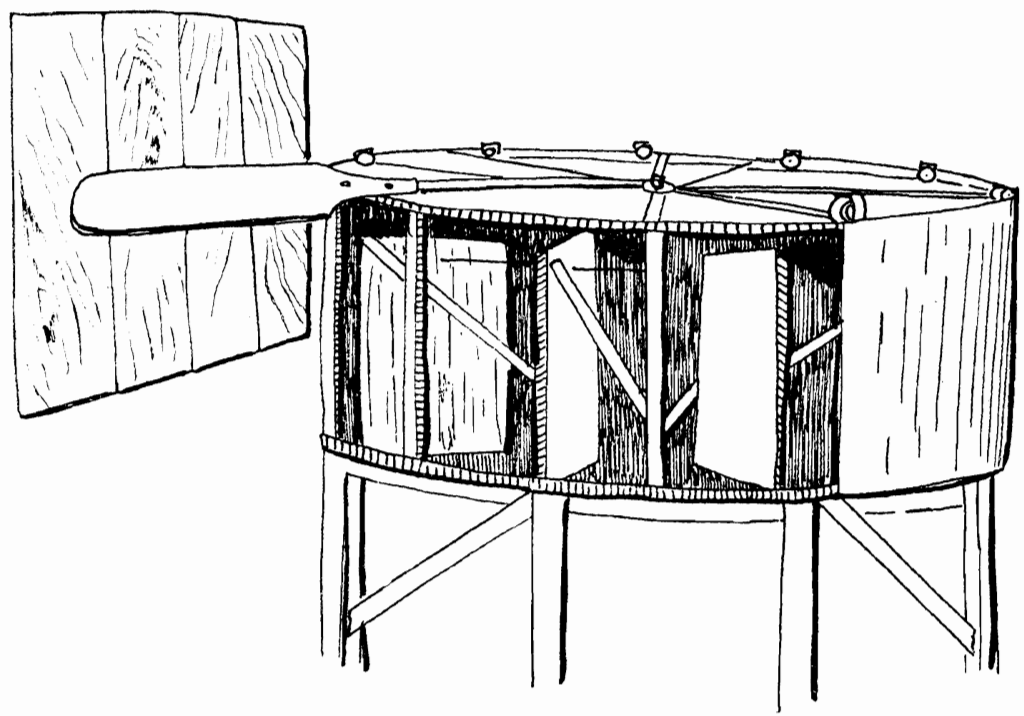

FIG. 35. A sketch of the Wynn Merry-go-round windmill, Berwyn, Nebraska, showing revolving hood which is guided by a rudder so as to protect half of the fans and to expose the other half.

The mounted Merry-go-round, as designed by W. Wynn, of Custer County, consists of a number of fans revolving about a central axis. About the same axis also revolves a semi-circular hood, as the cut will show; thus exposing half of the fans, and shielding the other half. The revolving hood, which seems to be an original as well as a good idea, is easily guided by a large vane. Its construction is simple, its cost small, and it is well adapted to go on the tops of sheds, cribs, and outbuildings, thus doing away with towers. The shield might be lightened somewhat, for it does not seem necessary that it should be a full semi-circle; a quadrant or a quarter circle would do just as well, and will weigh less and cost less time and money. Mr. Wynn's shield runs upon friction rollers. When the mill is to be thrown out of gear, the guard is simply revolved until it covers all the fans on the windward side. Small and medium sized mills might be constructed in this way. For medium and large Merry-gorounds the writer would propose a design such as is shown in Fig. 36. Here the fans, which may be large or small, as desired, 


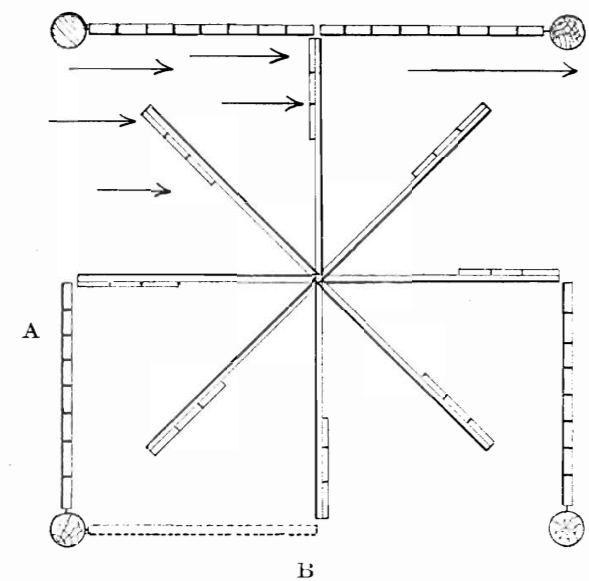

FIG. 36. Ground plan of a form of Merry-go-round proposed by the writer. Diameter twenty to twenty-five feet or more. Each of four posts carries a gate which may be opened and closed to admit or shut out the wind. Each gate is to be so arranged as to turn backward through an angle of $270^{\circ}$, as from position $\mathrm{A}$, to position $\mathrm{B}$.

are exposed to the wind on one side, and shielded on the other, by means of gates, as is apparent in the figure. In case of high wind the gates can be partly closed, thus checking the rate of the mill, or they may be closed altogether, thus stopping the mill.

A model built by the writer, on this plan, worked admirably, and later a test will be made by erecting upon the University farm a trial mill, and a report of success or failure will be made in a subsequent paper.

A singular Merry-go-round is reported by Mr. E. E. Blackman, which according to his account, does excellent work. "It irrigates ten acres near the Colorado line," where semi-arid conditions prevail, and where the test is all the more severe. This Merry-go-round is twenty-four feet in diameter, and at the extremity of the long arms, swinging doors of light wood, four feet wide and six feet high, are so attached that they swing like a flag, edge to the wind when traveling against it, but broadside when traveling with it. This mill cost the surprisingly small sum of four dollars and seventy-five cents, exclusive of labor.

The swinging doors, it should be stated, are apt to cause a great deal of resistance to the wind, and consequently retard it to just that degree. 


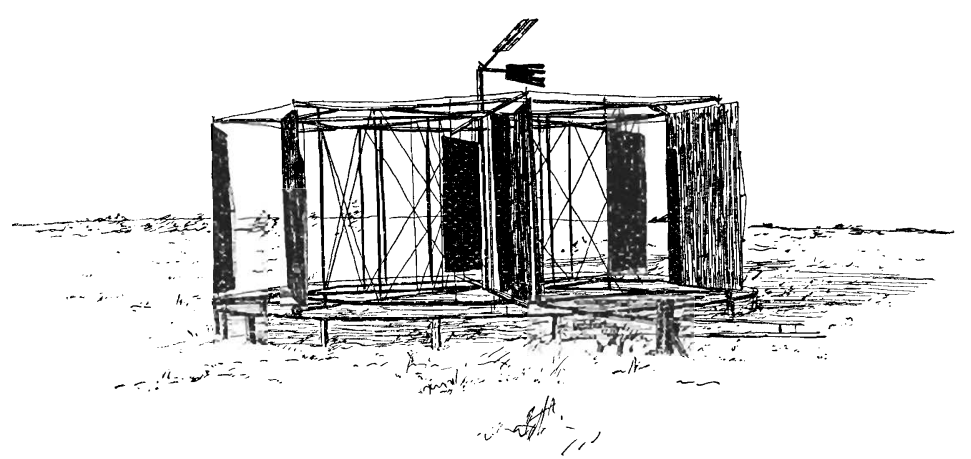

FIG. 37. A Merry-go-round designed and built by Mr. S. S. Videtto, Lincoln, Nebraska. This is an attempt to design a mill of unlimited size and power. Diameter of mill forty to fifty feet. height twelve to fourteen feet. Rurs on a circular steel track. Experimental nilil.

A similar, though larger, and much more elaborate Merry-goround is that of S. S. Videtto, on a ridge near Lincoln. This mill has a diameter of about forty feet, and the fans are twelve to fourteen feet high. The whole structure is carefully designed and well made, solidly braced, and runs upon a circular steel rail.

This is an experimental mill, and it is to be hoped that this, or some equally powerful mill, may yet be perfected.

In many of our river valleys water is to be had in unlimited amounts within ten feet of the surface. It is only a question of raising it so that it will flow upon the land. A powerful mill, if such is possible, will aid materially in irrigating in many places where ditches are impossible.

However impracticable and useless many inventions of our farmers may appear to be at times, yet at all times it is apparent that this inventive movement is an attempt to meet a demand, and who dares to say that the sum total of these inventions may not yet lead to the solution of some of our irrigation problems.

Individual work along these diverse lines seems to be worthy of encouragement, rather than discouragement, and when the matter is worked out by practical men it will doubtless be possible to write with still more enthusiasm concerning the success of the homemade mill.

The cost may be still further lessened by learning to arrange 
cribs, carriage houses, and outbuildings with respect to the construction of the Merry-go-round, or other types of mills. Thus by lowering their cost, and by raising their efficiency, according as old models are improved upon, we may with reason expect of these mills still greater usefulness.

\section{TURBINES OR OPEN FACED MILLS}

In the open faced or Turbine mill we realize a form which is considered to be much in advance of the preceding. Here there are great and varied possibilities, and one can certainly find the mill suited to his needs.

The writer would classify the Turbine mills about as follows, arranging them in the supposed ascending order of their importance: First, Holland mills; second, Battle-ax mills, including those with two, four, six, eight fans, and the Giant Battle-axes; third, Mock Turbines, which so closely resemble the shopmade product as to be scarcely distinguishable at times, and which include the fixed Turbines, the revolving Turbines, with and without rudders, and the giant Turbines; fourth, the reconstructed Turbines, that is, the secondhand or fallen Turbines bought and fixed over. The last and most efficient of all is a fifth division, the shopmade mills, not discussed in this report, which considers instead the homemade mill.

The Turbine represents what is believed to be the highest order of windmills, and other things being equal it is the one to be recommended. They seem to be as easily built as the Jumbo itself, and they require less material, and are capable of a greater variety of modifications. The simpler forms, at least, are easily and cheaply built, and are plainly to be preferred, according to the writer's belief. 


\section{THE BATTLE-AX MILL}

The essential part of the Battle-ax mill is its axis, to which arms are attached, and upon the arms are the blades. The whole is mounted upon a tower made of lumber or of poles cut from the place; or it may be mounted directly upon some crib or outbuilding, thus still further simplifying it. The name Battleax is not inappropriate, for there is a possible resemblance in the arms and in the blade to the handle and blade of its precursor. The resemblance is still closer when one sees the mill in rapid motion. Then the blades seem to be chopping the air in opposite directions, and the name Battle-ax seems the more applicable.

There is one objection to the Battle-ax, but not a serious one; it is set in a fixed position with its axis north and south, and is inefficient when the wind blows from the east or west. However that objection is a trifling one, when it is remembered that our winds are ne:irly constant. There would be few days when the wind would render the mill inoperative.

The axis, which has already been described as the fundamental part, may be of wood, gas pipe, shafting, or an iron rod as suits the caprice of the builder. We have seen the axis made of a six or eight foot section cut from a good straight pole, say seven or eight inches in diameter. This was trued up at the ends by a drawing knife, so as to fit and turn easily in its wooden bearings. We have seen eight-inch pieces from the lumber yard treated in the same way.

Again we find them with round iron journals set into the ends of the axes, which doubtless run more smoothly in the wooden bearings. Others are made of iron throughout. In many instances discarded farm machinery with its bearings, cog wheels, etc., are adapted to this purpose. The most ingenious axes which we found were built by taking the axle, hub and all, of an old wagon or buggy, and fastening these to the crude tower. Thus it was an easy matter to secure excellent journals and bearings, for the axle continued to run in the thimble turned to fit it. These were true bearings, and when properly oiled were prac- 
tically frictionless. The arms were then bolted firmly to the axis, and if necessary were further strengthened by tying them together with twisted fencing wire.

These mills, which seem to be preferable in most cases to either the Jumbo or the Merry-go-round, vary in size up to those which are a full sixteen feet in diameter. They are subject to a limitation in size, and eighteen to twenty feet approaches the limit, for ordinary purposes at least. Accordingly if still larger mills are desired, one may have to choose the Jumbo or the Merry-go-round.

The ordinary size as seen in daily use raising water for the house, stock, or for irrigation of a small patch, is about eight or ten feet in diameter. The simpler and earlier forms are the more typical, and are well represented by any one of the many Battle-ax mills built by the German farmers around Grand Island.

That of Jacob Geiss is quite representative. It is a twelve foot wheel, with a heavy wooden axis eight feet long, carrying four fans, each three by three feet. The whole is mounted upon

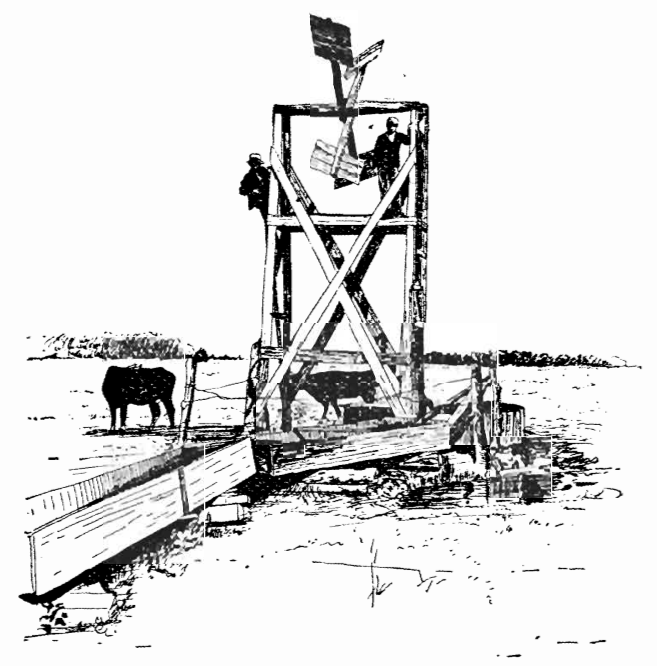

FIG. 38. Side view of the typical Battle-ax windmill of Jacob Geiss, near Grand Island, Nebraska. Diameter of wheel twelve feet; axis eight feet long; blades three feet square. Pumps water for 125 head of cattle. 
a well built and sightly tower, and pumps water from a shallow well for one hundred and twenty-five head of cattle. Such mills need not cost a farmer anything beyond labor, but this particular one, which is especially well built, cost ten to twelve dollars.

The Battle-ax is the prevailing form of homemade mill in central Nebraska.

West of Grand Island, at Overton, we found other similar examples of which we choose the mill of Mathew Wilson as being particularly suggestive and instructive. The Wilson estate covers sixteen hundred acres, accordingly several shopmade mills as well as several homemade mills are necessary. There

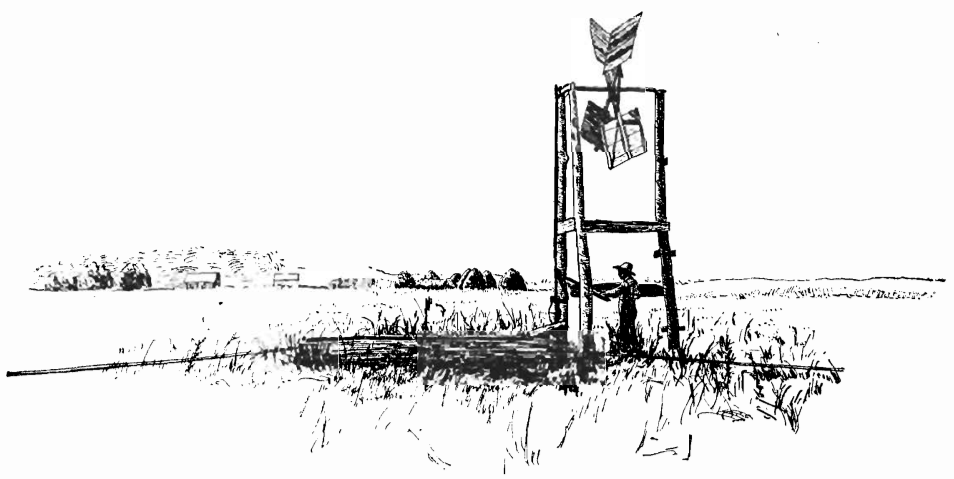

FIG. 39. One of the Battle-ax milis on the 1,600 acre farm of Mr. Mathew Wilson near Overton, Nebraska. This mill cost $\$ 1.50$, and pumps water for fifty head of stock, on a quarter section, besides irrigating a one acre garden. Water is conducted from the tank to the rows by one-inch galvanized pipe. The axis of the mill is the axle of an old buggy. Diameter of wheel eight feet; blades two and one-half by two feet.

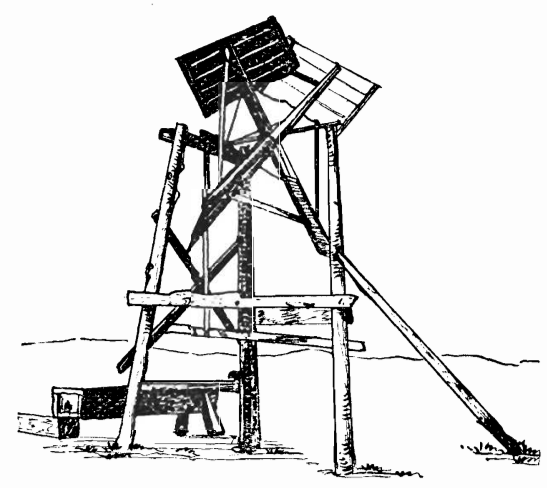

FIG. 40. A. Battle-ax on cottonwood poles, near Overton, Nebraska. 


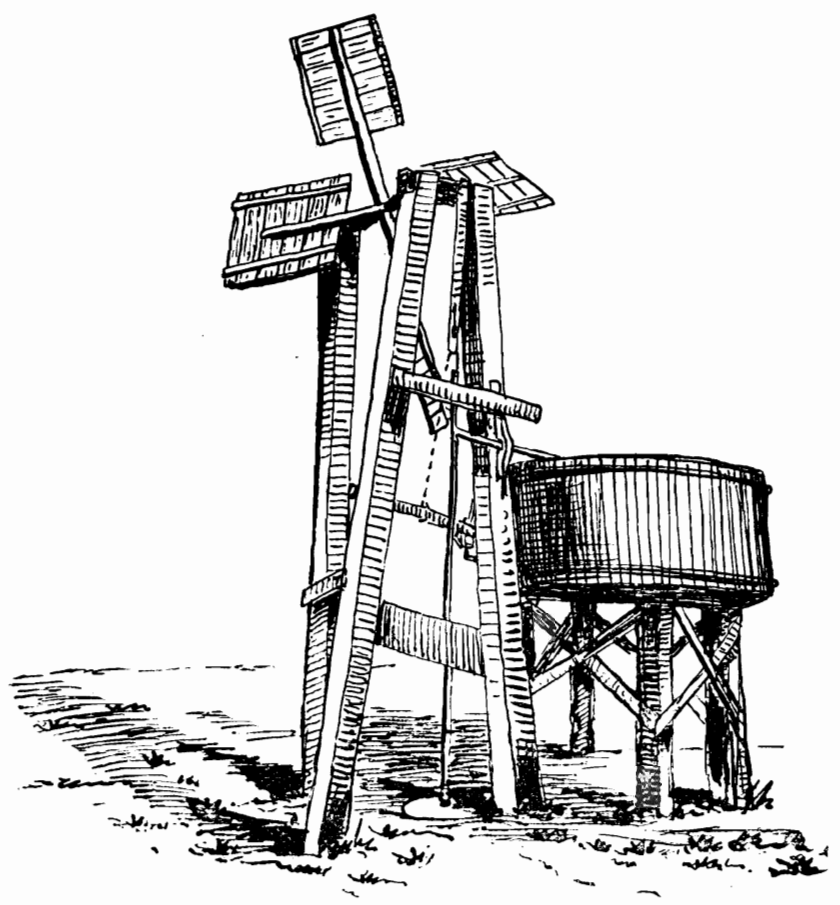

FIG. 41. The Battle-ax windmill and tank built by J. A. Carrell, near Overton, braska. Cost of windmill, including a thirty-barrel tank and all incidentals, \$25.00. De to water twenty-three feet. In use since 1896.

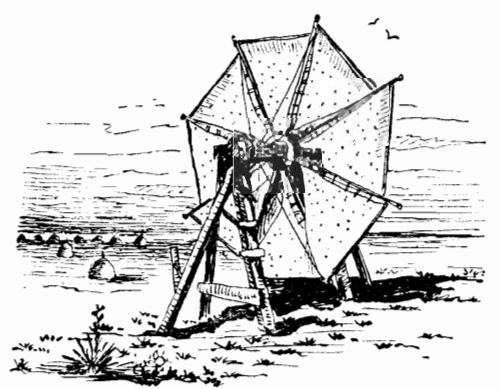

FIG. 42. The Defender mill, an eight fan Battle-ax with canvas sails. Kansas. 
were severad hundred head of cattle, besides other stock, all of them demanding a supply of water. To assist the regular mills two Battle-ax mills were built, each upon a quarter section of pasture land, and each pumped for fifty cattle, and in addition one watered the garden patch, which is a good record for a mill costing but one dollar and a half. The towers were built of poles cut from the timber claim, the lumber was odds and ends from the place, while the axis-a very ingenious affair-was an old buggy axle. The thimbles were taken out of the hub and fitted to the tower, and the spindles ran in the thimbles. One nut was removed, and a crank screwed on in its place, and the mill was all but done; it only remained to bolt the arms to the axis, and to nail on the blades. The tower, a very rigid one, was a tripod of three heavy cottonwood poles, set in deep holes with the earth tamped around them, thus anchoring them securely.

The six, eight, or many-fan Battle-axes differ in no essential respect from the foregoing, save that the blades become paddles oftentimes, otherwise they are identical. Fig. 43 shows the eight

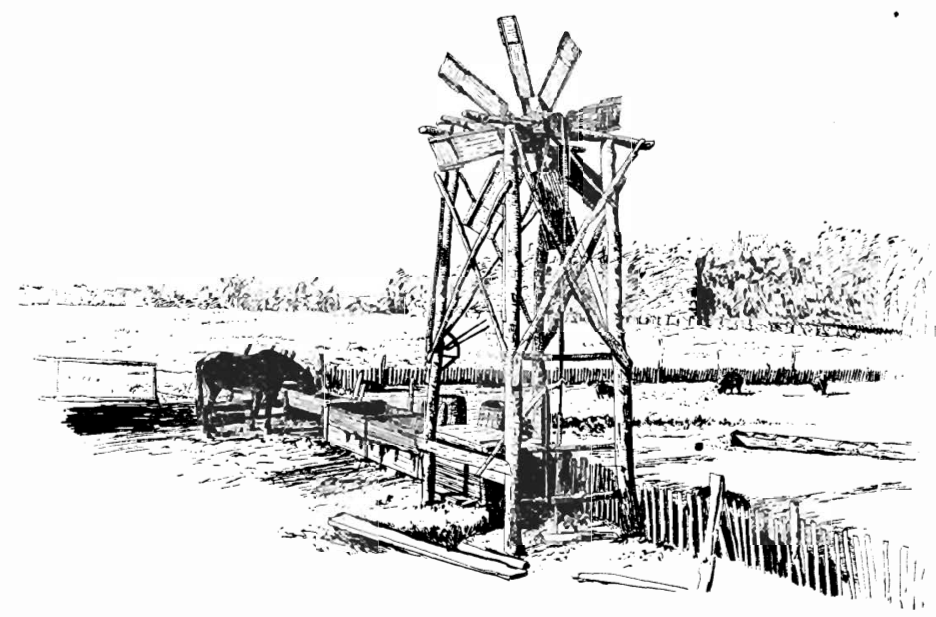

FIG. 43. Front view of the eight-fan Battle-ax windmill of Mr. Diedtrich Huennecke, near Grand Island, Nebraska, showing brake with wire leading down to old wagon brake, seen below. The fans are fixed to the driving parts of an old threshing machine. Tower and cross-braces made of cottonwood poles. Diameter of wheel twelve feet: cost $\$ 14$, in- cluding a large tank; cost of mill alone $\$ 6$ to $\$ 8$. Pumps water for the stock. 


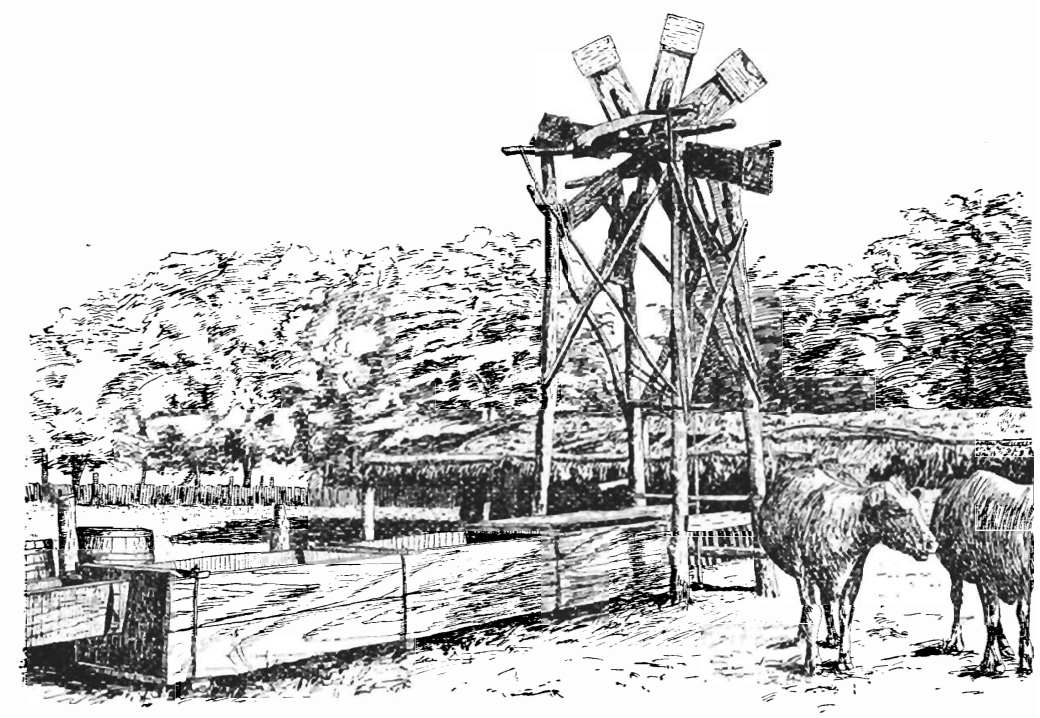

FIG. 4t. Rear view of the above.

fan Battle-ax of Diedtrich Huennecke, near Grand Island. Thi mill is a fine example of the adaptation of waste lumber an waste machinery in windmill construction. In this mill we foun incorporated old lumber, boxes, rails, wire, parts of the fram and gearing of an old thresher, and even the brake of an ol wagon. These antiquated pieces of machinery were so fa rejuvenated that they were doing duty once again for thei owner.

The whole mill, including a large water tank, cost fourtee dollars. The mill alone cost from six to eight dollars.

It was a sightly, ingenious, and strong mill, and seemed to $\mathrm{b}$ doing the work of mills that cost many times as much. Th brake was an ingenious and cheap affair and altogether as effi cient as simple. In adapting the framework, and certain mechan ical parts of an old threshing machine to use in his windmill $\mathrm{h}$ simply took advantage of a pulley attached to the main drivin: rod. Two rails were so fixed as to cramp this pulley when lever below was pulled; the lever being that from the brake $\mathrm{c}$ an old wagon. The construction of this mill and all its part will be shown at another time. 


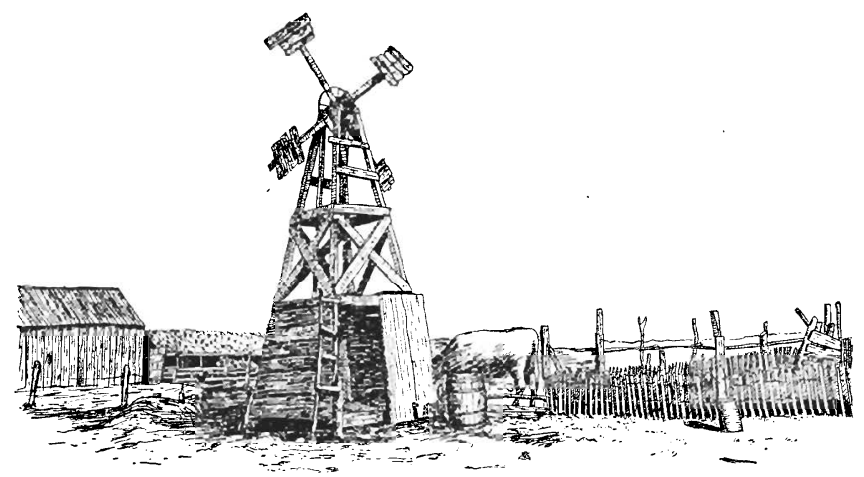

Frg. 45. The Battle-ax windmill, tower, milk house, and stock troughs of Fred Woulf near Grand Island. Diameter of wheel ten feet; cost $\$ 3$ to $\$ 5$; pumps water for forty head of cattle.

At Cozad we found a Battle-ax mill owned and built by Mr. E. Folker, which was especially well made and nicely painted, the fans Venetian red, the tower white. It furnishes a good key to the probable outlay for such a mill when made of new material put together with extra care, and even decorated with paint.

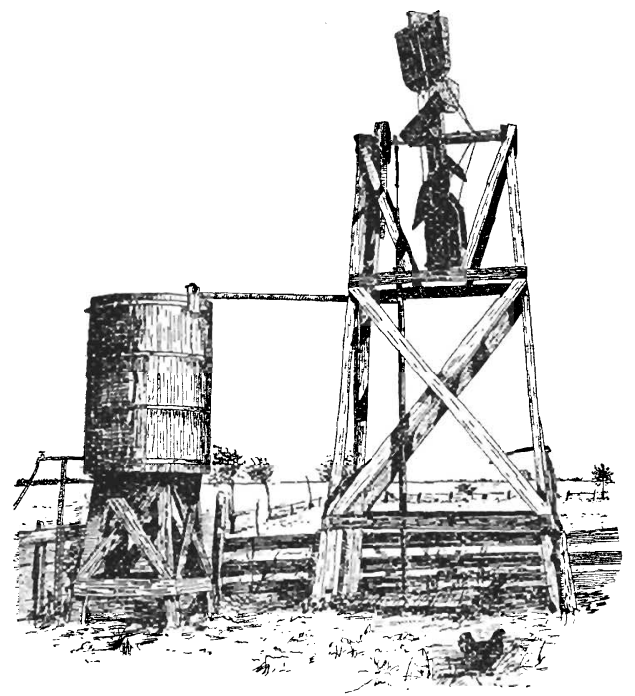

FIG. 46. The eight-fan Battle-ax windmill designed and built by Mr. E. Folker, Cozad, Nebraska. Diameter of wheel ten feet. Pumps for the lawn, house, and barn. The mill, tower. and tank are well made and painted, and cost $\$ 15$. 
The total cost was fifteen dollars. It pumps for lawn, house, and barn. The toggle-joint brake could scarcely have worked better. By it the mill could be checked or stopped by a touch. Though not the simplest kind of a brake it is a good one, and it will be figured in a subsequent paper.

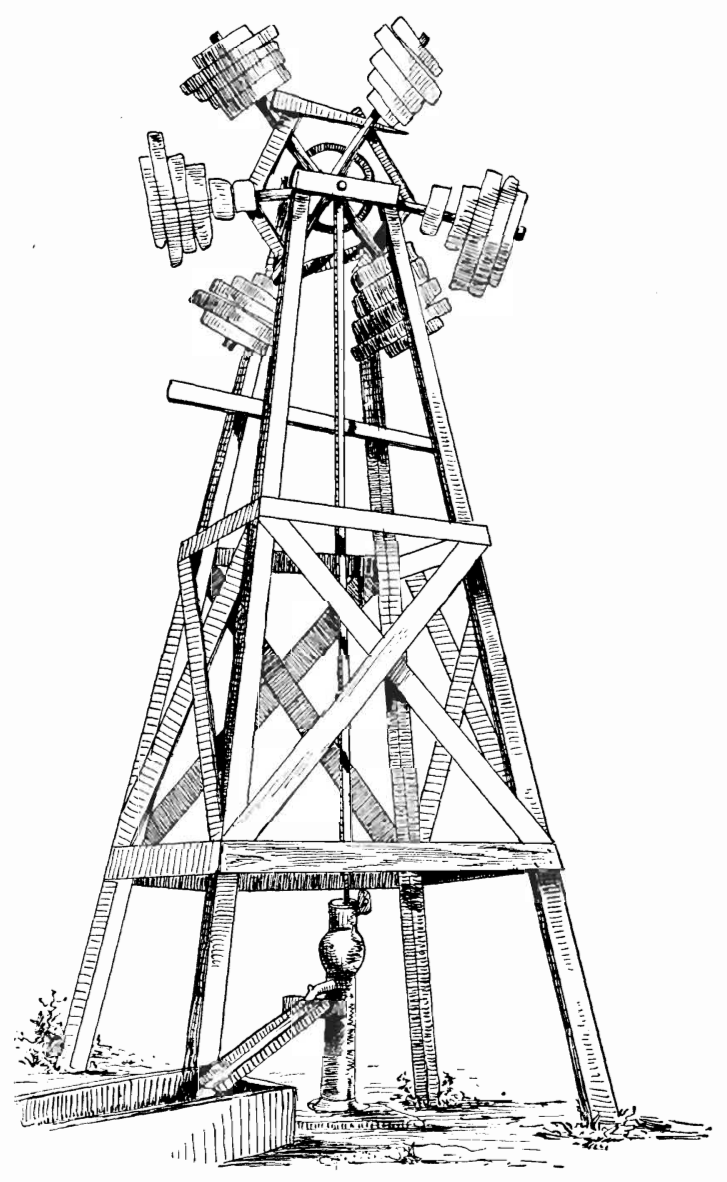

FIG. 47. The Schroeder barrel-stave, Battle-ax mill four miles north of Grand Island, introduced to show that almost any waste material may be used in the construction of the homemade mill. The writer has seen new lumber, old lumber, weather boarding, laths and shingles, grocery boxes, barrel staves, tin from old roofs, coffee 'sacks, and old bagging, canvas, etc., turned to good account in making homemade mills. Old barrels are procurable everywhere, and the barrel staves furnish lumber at once light and strong enough for the fans of Jumbos, Battle-axes, and other inexpensive mills. 
The average Battle-ax mill has a diameter of about nine or ten feet, some a little less, some more; and from this they run up to the giant Battle-axes, sixteen feet in diameter.

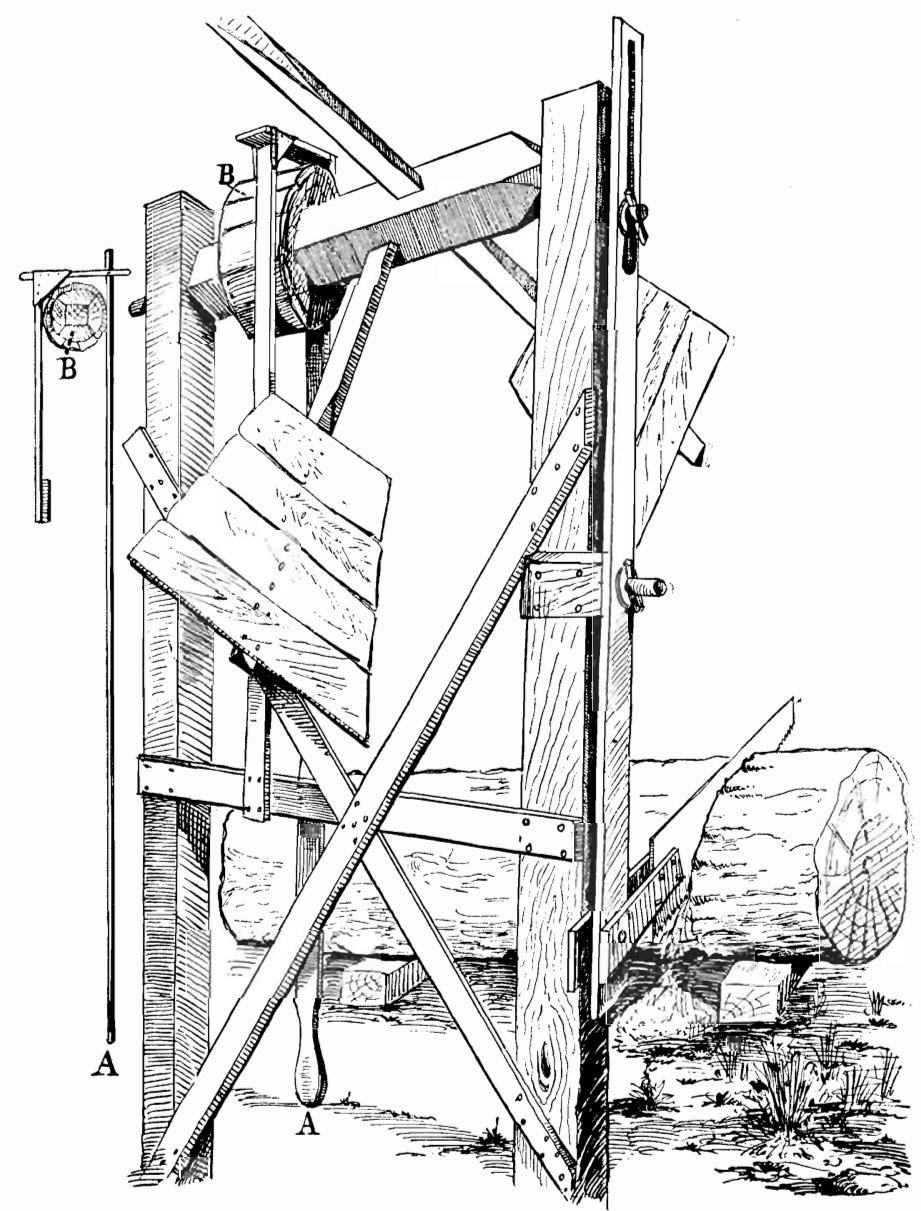

FIG. 48. The Battle-ax windmill of Mr. A. G. Tingley, Verdon, Nebraska, as seen:sawing a thirty-inch log. Diameter of wheel ten feet. The wooden drum and brake is self explanatory. This mill saws the wood for the family, and requires but little superintendence. To the left is seen a plan of the brake. The handle A.cramps upon the wooden:drum. B. It is a cheap, simple, and satisfactory device. 
The best examples of such were found on the farm of J. S. Peckham, and on that of his son, E. L. Peckham, some five miles southwest of Gothenburg, in Dawson county. These are wind engines which must surprise anyone who may be at all skeptical as to what may be done with homemade mills.

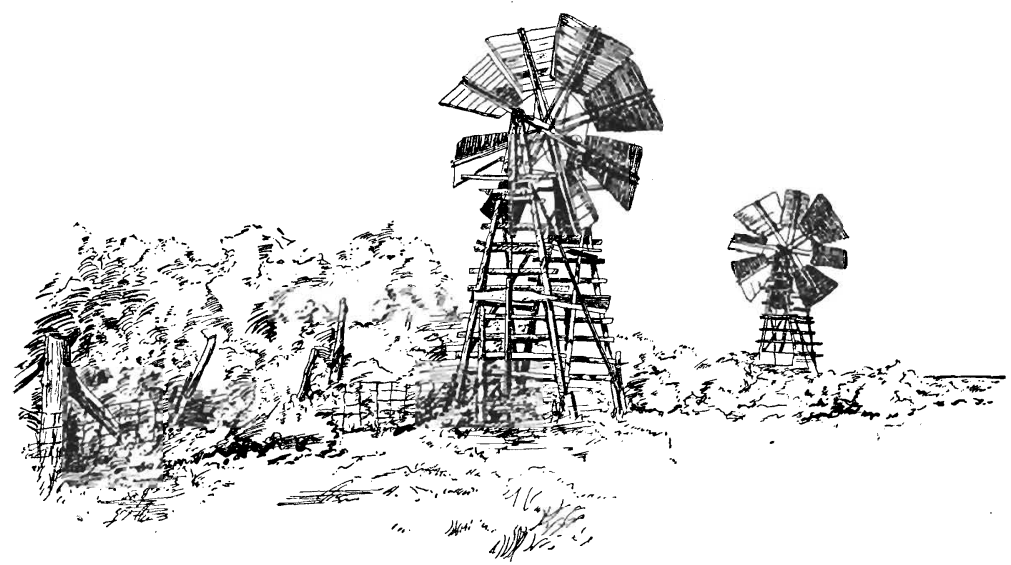

FIG. 49. Twin Battle-ax windmills on the thousand-acre farm of Mr. J. S. Peckham, near Gothenburg, Nebraska. Towers are made of four-by-fours, cross-braces of two-byfours; stand twenty feet high. Diameter of wheel sixteen feet; fans five and one-half feet long, five feet wide at the top tapering to two and one-half to three feet at the bottom. Used in irrigating a fifteen-acre orchard. Capacity of each will average nearly one thousand gallons an hour in a fifteen mile wind. Cost \$25 each.

As we approached this fine farm of one thousand acres, we saw the commodious house, the barns, and outbuildings, the timber claim, the young orchard, and a row of six stately windmills which gave a decidedly favorable impression. Four of the mills were shopmade, of various makes, and two were Battle-ax mills of the proprietor's own make.

The two Battle-ax mills stood side by side near the fifteenacre orchard, which they were built to irrigate. Here were growing, apples, plums, peaches, small fruits, and grape vines, and yet this is the very region where they say fruit cannot be grown. Had the twin Battle-axes pumped the water into storage reservoirs instead of applying it directly, it would have insured a more even distribution of the water, and even better results. This was the only orchard we saw for miles around. 
These twin Battle-axes were made of new lumber, and exceptionally well bolted and braced. The towers were twenty. feet high and spread to sixteen feet at the base, the corner posts being four by four yellow pine, the cross-braces two by four vellow pine. The axis was eight inches square and sixteen feet long, and the diameter of the mill sixteen feet. Each of the eight arms carried a heavy wooden fan, five and one half feet long, and five feet at the top, tapering to two and one half to three feet at the bottom. Thus each of eight fans exposed nearly twenty-five square feet of surface to the wind. The exercise of economy was not necessary in this case, so a close account of expenses was not kept, but the probable expense was reported at about twenty-five dollars each.

The rate of the wind and the amount of water was measured, giving the following results: Mill No. I with two three-inch cylinders and a ten-inch stroke, with one valve in bad order, pumped water from a forty-two foot well at the measured rate of about fifteen thousand gallons in twenty-four hours, in a thirteen and a half mile wind; mill No. 2 had four-inch cylinders and was in better repair, and under the same conditions as No. I pumped nearly one thousand gallons per hour. This amount was greatly exceeded when the wind rose later to fifteen miles an hour. If possible, the discharge of both mills will be measured for different wind velocities, and will be reported in a succeeding paper for the benefit of those who may be interested.

About a mile distant on the farm of the son, Mr. L. L. Peckham, was a similar Battle-ax mill, save that it was built with even greater care, and was used similarly to irrigate a garden and a young orchard set out a year or so before. This mill cost seventy-five dollars, including new lumber, two pumps, and all other incidentals.

By striking an average of the cost of these three mills we may judge that the probable cost of such an undertaking will not fall much below forty or fifty dollars where new material is used. In case of stricter economy the cost may fall below twenty-five dollars. There is no reason why the tower should not be built of poles cut from the place, and the axis and arms too for that mat- 
ter. Then old lumber and boxes make about as good fans as new, and if these items of expense are eliminated the cost is reduced to the amount necessary for hardware.

This is a commendable pattern of mill, and one which may cost much or little, according to the builder's means.

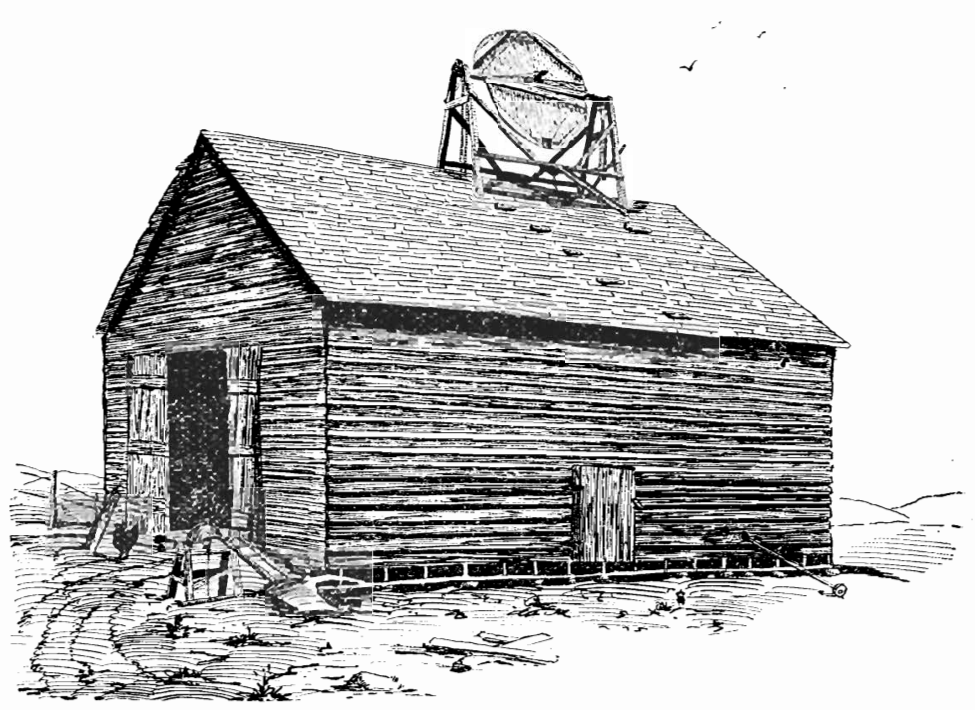

FIG. 50. The two-fan Battle-ax windmill of Mr. Elmer Jasperson, Ashland, Nebraska, mounted on the wagon shed and corn crib. The shed stands north and south. The mill in its present position stands with its two fans brought together, forming a circle with edge to the wind, hence out of gear. See Fig. 51.

The remarkable two-fan mill of Elmer Jasperson near Ashland we must class with the Battle-axes. It is a sort of adjustable Battle-ax, the fans turning upon the short arms to throw it in and out of gear. When thrown out of gear the two great semi-circular fans make a ten-foot circle with the edge to the: 
wind; accordingly it remains stationary. However when the two fans are slightly oblique, then the force of the wind is felt, and the mill starts.

This seems to be an original mill, only one like it being known elsewhere. The cost was exactly eleven dollars, and the mill in

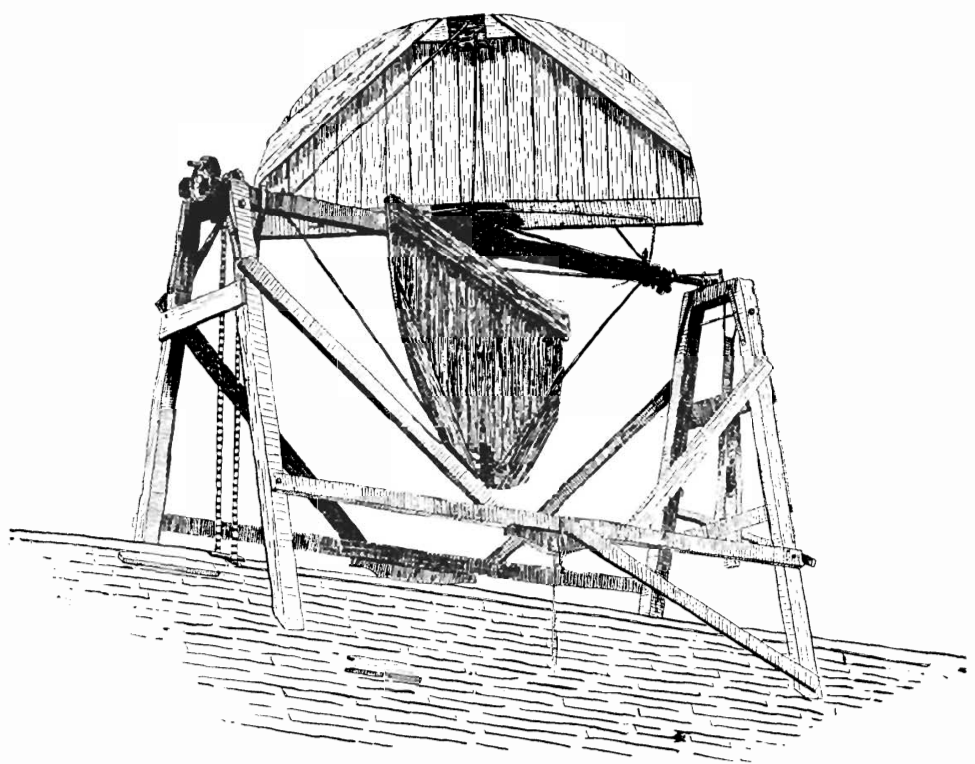

FIG. 51. The two-fan Battle-ax mill designed and built by Mr. Elmer Jasperson, near Ashland, Nebraska. It is mounted on a shed which stands north and south. that is. in the direction of the prevailing wind. The power is transmitted from the fans to the corn sheller and feed grinder by means of sprocket wheels and chain. Diameter of wheel ten feet. Cost of mill $\$ 11$.

return runs a two hole corn sheller, a feed grinder, and the grindstone. This is its practical efficiency; its true efficiency will be measured and reported at another time.

This is the mill to which the Lincoln State Journal, in pursuing the inquiry into the homemade mills of the state, recently awarded a prize for originality and ingenuity. 


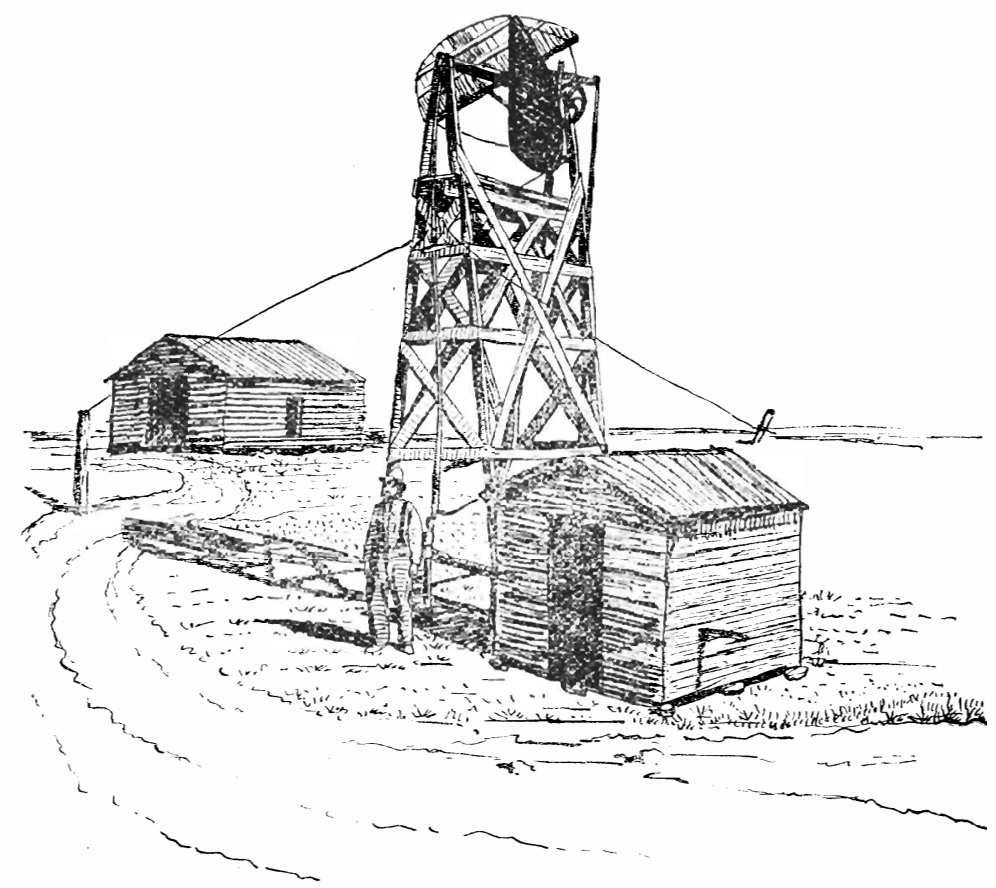

FIG. 52. The homemade windmill of Dr. Edward Johnson, near Fullerton, Nebra This mill was built for Dr. Johnson, on his farm, by a carpenter at a cost of $\$ 22$. "It ] as well in a light wind as any ordinary mill." Tower twenty feet high; diameter of seven feet. 
In making the homemade windmills a good many lose sight of the fact that their mills may be built in such a way that they will naturally swing around and stand in the wind with the intervention of a rudder, and this brings us to the vaneless Turbines.

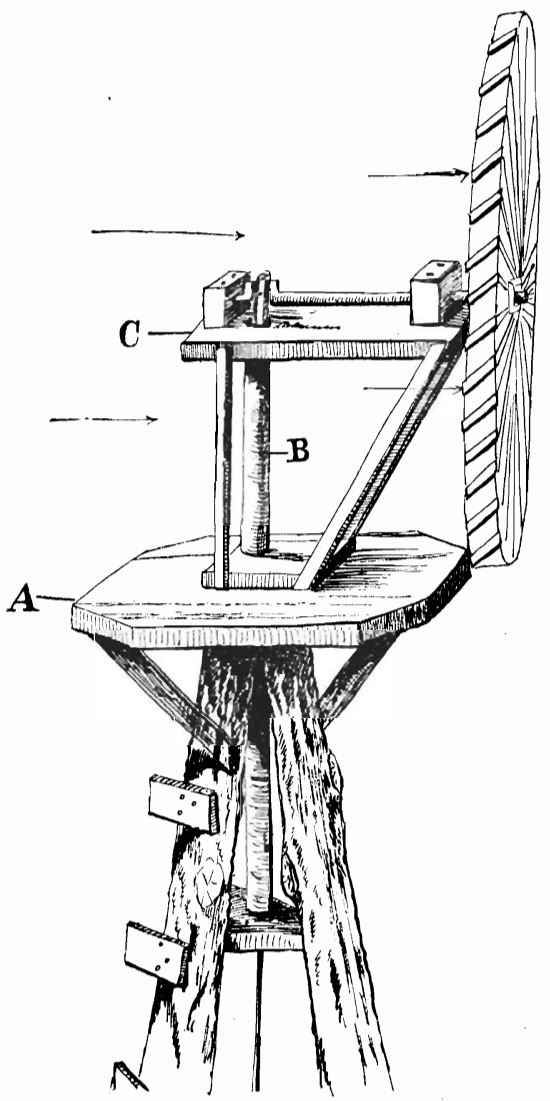

FIG. 64. A plan for the construction of simple vaneless Turbines as proposed by the writer. Tower of poles. A, platform; B, stationary axis of three-inch gas pipe around which turns the platform $\mathrm{C}$, which supports the mill. The arrows show the direction of the; wind. 
A small Holland mill built by Wheeler \& Bennett near Grand Island, proved very interesting because of the use to which it was put. People living in the smaller cities and towns find it convenient to own their cows. Accordingly the town herd and herder, generally a boy on horseback, is a fixed institution. In the morning the cows are assembled and driven to pasture, and watered and cared for during the day, and returned at night.

By putting up this simple mill the owners of a neighboring pasture were able to accommodate a large town herd to advantage. Similar mills are to be found near Beatrice, Omaha, and elsewhere, but the best example is to be found on the farm of August Prinz near Chalco. It is a fine, stately scructure, and a

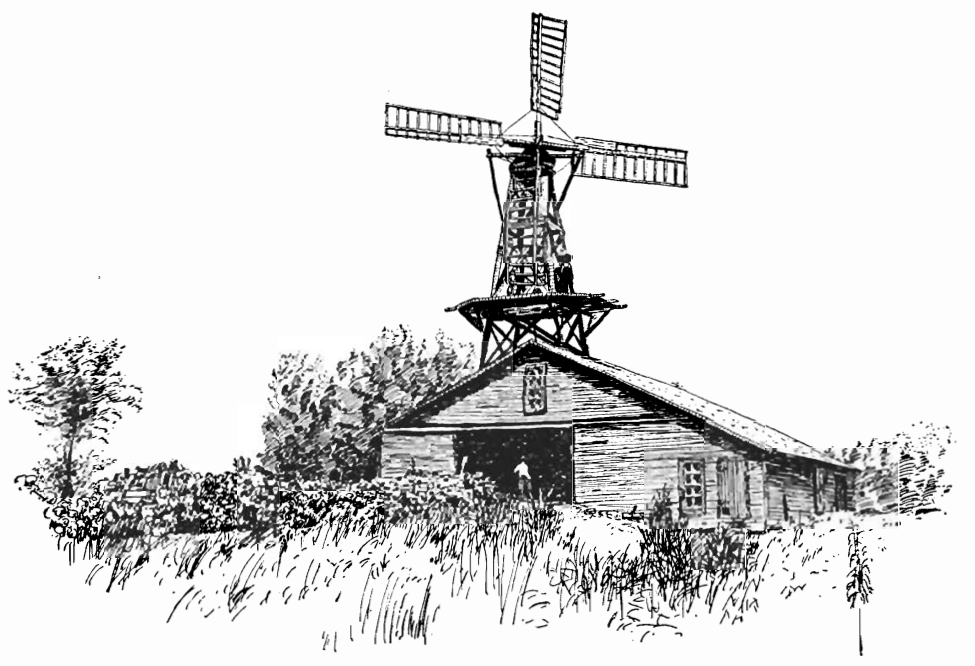

FIG. 54. The large Dutch mill built by Mr. August Prinz, Chalco, Nebraska. Diameter of wheel thirty-six feet; capacity two hundred to three hundred bushels of ground feed a day, according to the wind; efficiency between six and eight horse power. Runs an eight horsepower feed grinder. Cost $\$ 150$. The designer prepared his own models, and had them cast in Omaha.

sort of landmark. Its cost, one hundred and fifty dollars, is large, but not out of proportion to the work performed, for it runs an eight horse power feed grinder, and turns out a grist of two hundred and even three hundred bushels of ground feed per day, in the ordinary winds of winter, when it is in use grinding feed 
for stock. We had no means at hand for measuring its true efficiency, and assume that its working efficiency is at least eight horse power, as measured by the grinder which it runs. Furthermore it grinds away without superintendence, for it elevates the grain, and discharges the grist into the proper bins automatically. In a good wind four sails give too much strength, so two are generally furled. The mill is so well built that its term of usefulness must continue for ten to fifteen years to come.

Many cannot afford so expensive a mill, nor is it necessary; but in cases where big work is to be done, then big machinery must of necessity be employed.

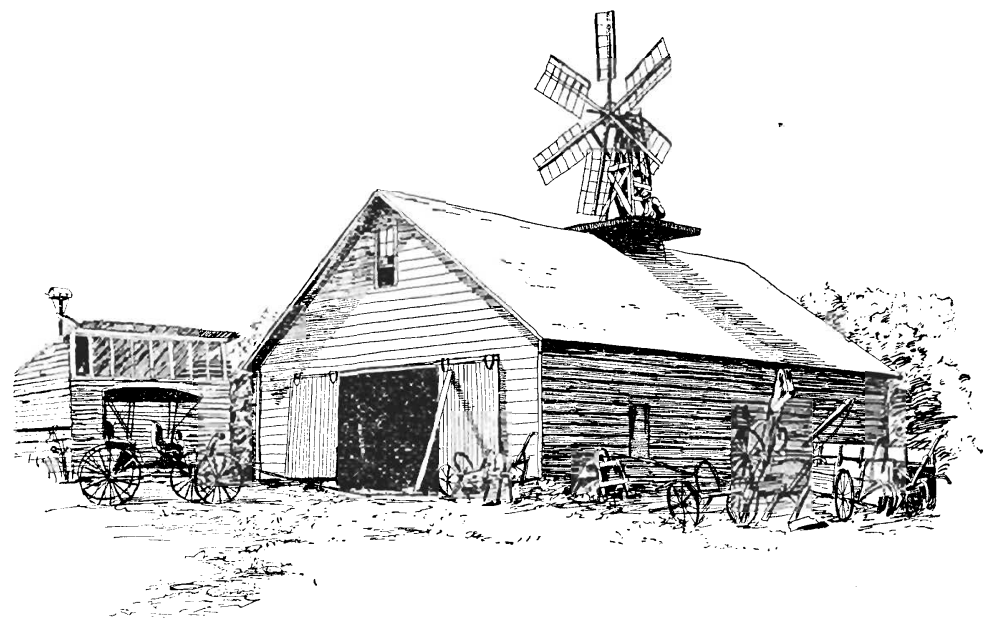

FlG. 5̆. The six-fan Holland windmill designed and built by Mr. Henry Borman, near. Portal, Nebraska. Diameter nearly twenty feet. Runs a six-horse feed grinder. Cost \$50.

A good average size is realized in the mill of Henry Borman, near Portal. This mill, like the Prinz mill, its direct progenitor, is a Holland mill, but with six arms instead of four. It is about twenty feet in diameter, instead of thirty-six, and runs a six horse power feed grinder, and its owner believes this to represent its efficiency. Doubtless it may be pronounced a four or five horse power mill. Even then it is not run full rigged, sometimes four sails, sometimes but three being used. The cloth sails have now been displaced by wood, because it is found to be easier and 
more expeditious to put up a thin board sail, which can instantly be shoved into place, than it is to unfurl and tie into place a duck sail. The capacity of the mill varies from seventy-five to one hundred bushels per day, according to the velocity of the wind.

Its parts are partly those purchased from an abandoned elevator, and partly those modeled by and cast expressly for the owner. The cost of this mill was fifty dollars. This, like the Prinz mill, could be geared to run large pumps if necessary. At present both simply grind feed for the stock.

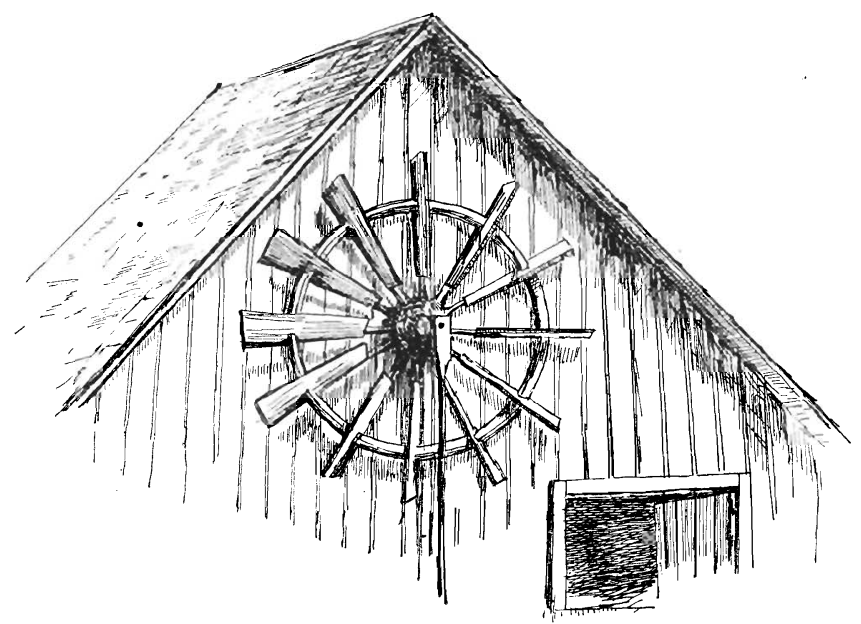

FIG. 56. Sketch of a Turbine windmill twenty miles south of Gothenburg, Dawson: County, which has neither tower nor ordinary working parts. The axle of an old wheel was bolted to the barn and blades were attached to the spokes and felly. A large spike in oneedge of the hub serves as the crank. Set face to the south. Cost nothing and pumps waterfor the barn.

\section{THE TOWERLESS TURBINE}

The simplest Turbine found thus far is one south of the Platte some twenty miles from Gothenburg, in Dawson county. This paradox of a mill consisted simply of the wheel, without tower, axle, crank, cog, or sprocket wheel, or other working parts, yet it worked and cost nothing, and defies competition along the line of simplicity. The farmer simply bolted an old wagon axle to a 
beam on the south side of the barn, put some axle grease upon the spindle, put on the wheel as of old, to which he had previously nailed slats or blades, screwed on the nut, attached the pump rod, and had the satisfaction of seeing it go, and at last accounts it was still running. The crank was simply a heavy spike driven into one edge of the wooden hub.

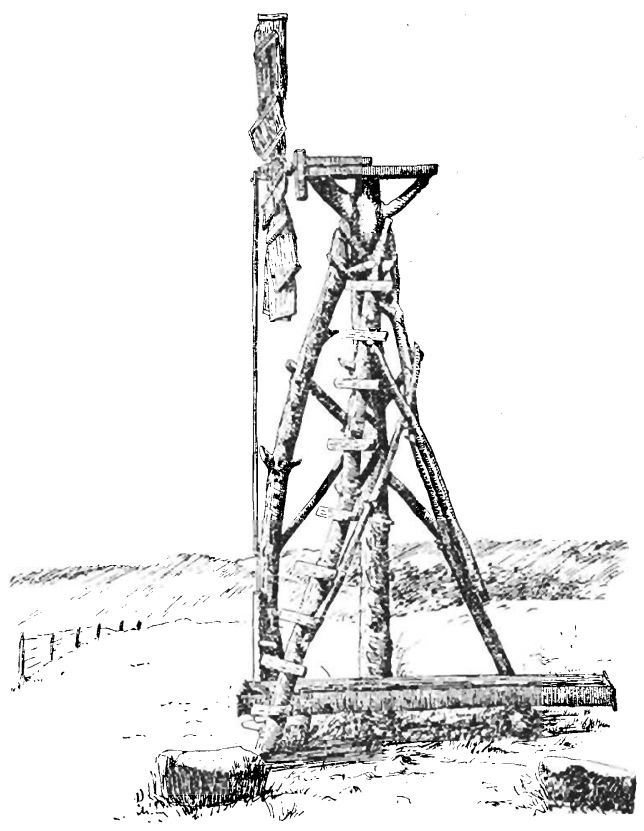

FIG. 57. Front and side views of a stationary Turbine mill as proposed by the writer. It consists simply of a rake wheel, or wagon wheel, to which blades are attached. This is fixed firmly by its axle to the tower. The crank is made by setting a metal pin in the hub two or three inches from the centre. Diameter of wheel eight to ten or twelve feet.

Drawn from a model built by the writer.

It was begun and done in a few hours, cost nothing, and pumps water. Where is its equal for simplicity? Of course it is a low grade mill, and runs only when the wind is from the south - its prevailing direction - and yet one must not demand too much of that which cost neither time nor money.

From this point one goes up the scale rapidly, and the mock Turbines begin to have towers; then they are made to revolve upon their towers, so as to face any wind; then they begin to have rudders to guide themselves automatically, and so on to the last degree of refinement. 


\section{STATIONARY TURBINES}

As the next simplest mill of this type we may select out of long list that of Fred Mathiesen, near Grand Island. It is full suggestions, though rough and cheap. Some locust poles c from the place were well anchored and roughly braced. $\mathrm{Up}_{\mathrm{p}}$ this tower was bolted the driving parts of an old self-binder, wi journals, bearings, and crank in place. To the crank of $t$ l sickle driver was attached a slender pole which was bolted to $t$ l pump rod, and to the other end of the shaft was attached $s$ rough board fans, and the mill was done, and cost but a dollar two at most, and pumped water for the stock in a large pastur

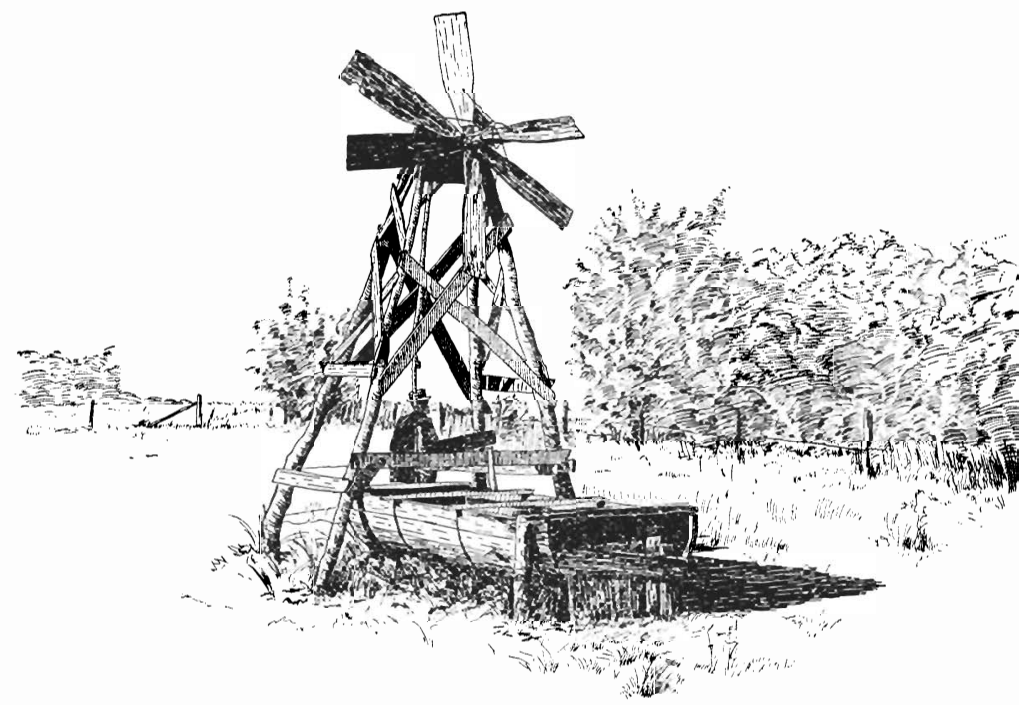

FIG. 58. The stationary six-fan Turbine mill designed and built by Frederick Mathies near Grand Island, giving front and side views. Made of parts from an old mower; twe] foot tower; nine foot wheel. Waters fifty head of cattle. Cost between $\$ 4$ and $\$ 5$.

The brake was the embodiment of simplicity. To stop th mill a rail was pushed forward between the fans, and nothin more need be said about this simple brake. To start the mi the obstruction was removed. These are mills of great numbr and variety, and only occasionally one admits of mention, th ground plan of all being essentially the same.

They are made in a set or fixed position upon the tower, ar. 
are consequently inefficient in winds from the east or west, but work well in those from the north and south.

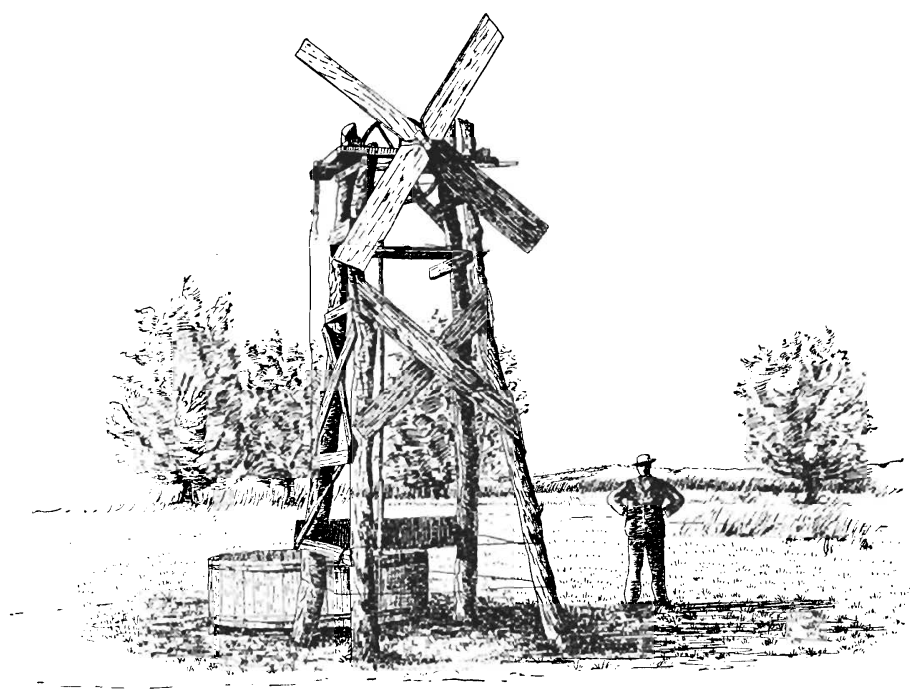

Fig. 59. The four-fan Turbine windmill of Mr. Friederich Ernstmeyer near Grand Island, Nebraska. Built on the framework of an old mower, the frame of which was bolted directly to the cottonwood tower. A brake (worked by the wire, to the left) rubbed against the cultivator wheel seen just back of the fans, so as to check or stop the mill. Diameter of wheel eight feet. Cost 32 cents (for a sixteen foot board for the fans). Pumps the water for the stock of the place.

A short distance beyond we found the set Turbine of Friederick Ernstmeyer, a simple four fan mock Turbine, which interested us because the mill was well built, and neatly mounted upon a cottonwood tower; the whole structure being attractive, if not even artistic, and yet the cost was but thirty-two cents (the price of a sixteen-foot board out of which the fans were built). This, like the foregoing, used the frames and working parts of an old reaper, so it ran upon fairly frictionless bearings, and responded to light winds, and pumped the water needed for his stock.

The brake was rather simple and ingenious. It consisted of a cultivator wheel, wedged securely to the axis; against this rubbed a beam guided by a lever at the ground. It was a small matter to either check the speed of the mill or to stop it outright. 


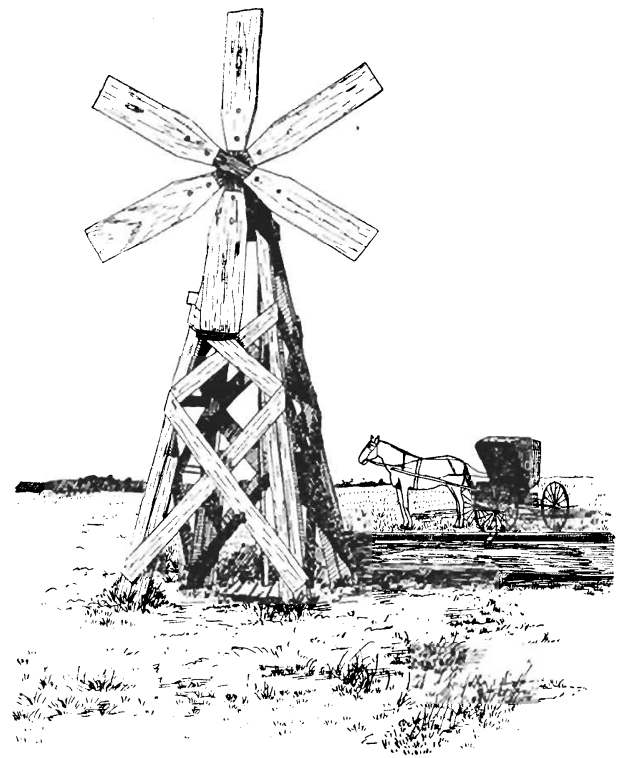

FIG. 60. Front view of the six fan set Turbine windmill of Fred Mathiesen near Gran Island, Nebraska. Diameter eight feet.

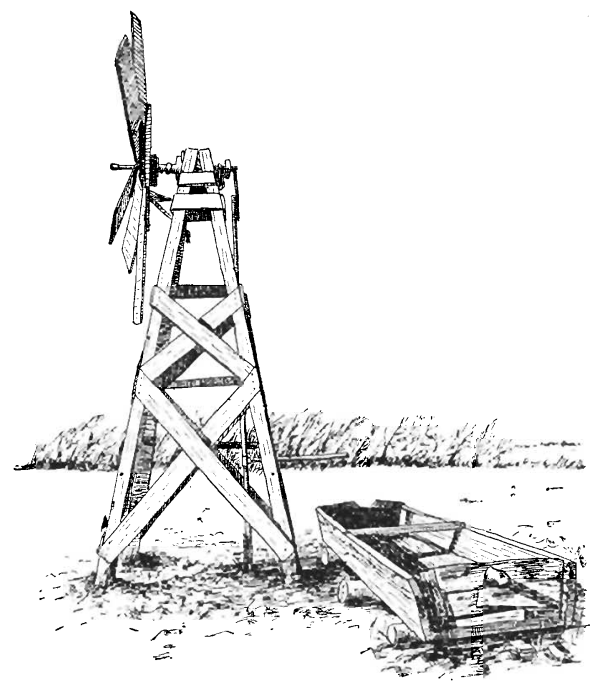

FIG. 61. Side view of the above. The mill is stopped by tying it to the tower by a rope 
These may be taken as fit representatives of the four fan, six fan, and eight fan Turbines, and we come to those having many fans. They are still stationary or fixed Turbines; that is, set for north and south winds only; aside from this they resemble the ordinary mills. A good example is found in the mill built by the Janak Brothers at Sarpy Mills, near Omaha.

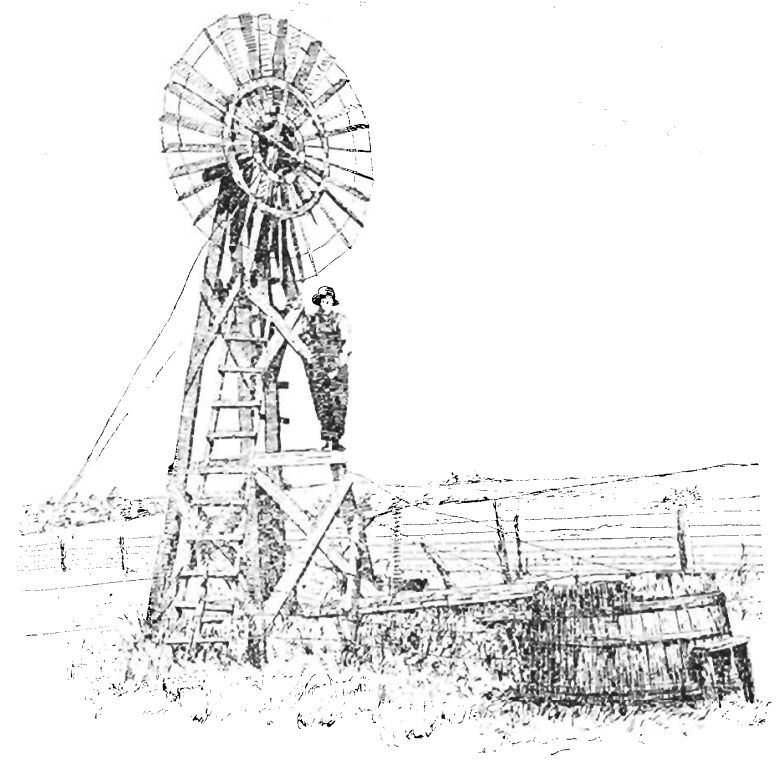

5. Fri. 62. Stationary Turbine windmill of the Janak Brothers, Sarpy Mills, Nebraska. The wheel. ten feet in diameter, made of weatherboarding, stands facing the south, and accordingiy is efficient in north and south winds only. This mill pumps water for thirty head of cattle, has been in service three years, and cost $\$ 3$ to $\$ 4$ including the tower. Compare this first attempt with the sixteen foot steel mill shown in Fig. 63.

The oider brother, who had arrived from Bohemia about three years before, found a neighbor in need of a mill for pumping stock water for about thirty head of cattle. Accordingly at a cost of three or four dollars he put up the ten-foot set Turbine shown in Fig. 62, and it has been in operation ever since. Its working parts are very simple, and are perfectly obvious from the sketch. The wheel was painted red and white, which gave it a finished look. The first attempt often inspires a second; accordingly when the younger brother arrived they at once put up a very 


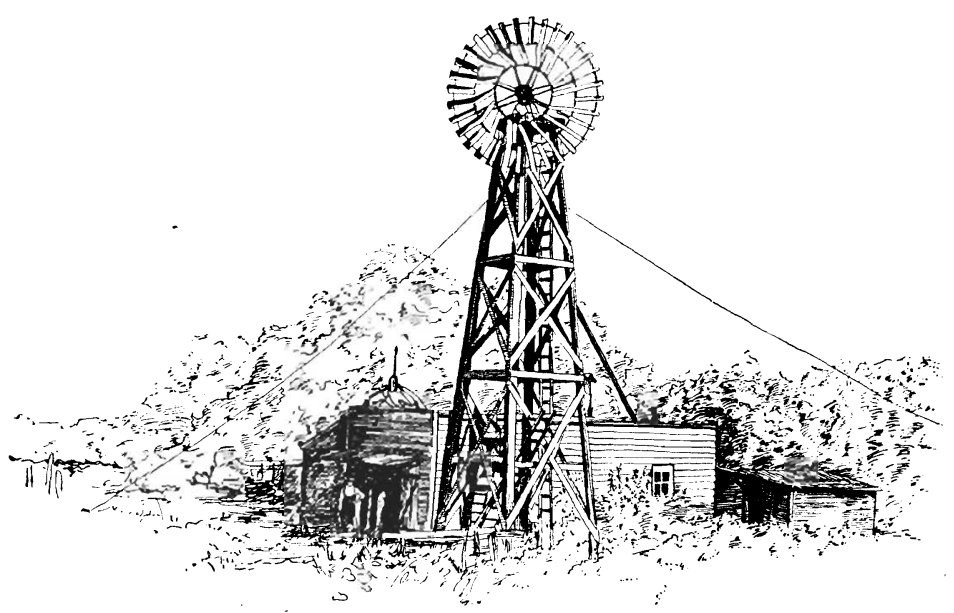

FIG. 63. A steel Turbine windmill designed and built by the Janak Brothers, Sarpy Mills, Nebraska. It runs the bellows, pump, grindstone, drill, emery wheel, lathe and other machinery. At present it is without a rudder, and it is necessary to set it face to the wind by means of a lever. Diameter of mill sixteen feet.

presentable and powerful steel mill, Fig. 63. And here we part company with the fixed Turbine, and come to a crude attempt at those which revolve on the tower to face any and every wind from whatever quarter. This is not done automatically, as in the case of the shopmade mill, but was accomplished by climbing the tower, and forcing the great footwheel around so as to iace the wind, there to stand until it was necessary to shift it again, which was not frequently. The important lesson in this mill is that one can get along (with a little inconvenience of course) without all the various attachments which we come to think indispensible, and yet secure good results.

The mill, when visited, was running as truly and noiselessly as any steel mill, and was running the pump, bellows, drill, polishing wheel, and grindstone, for the Janak Brothers' blacksmith shop.

This enables them to do a great deal of work and to do it well, and their patronage showed the success which the mill was largely instrumental in bringing to them.

Later they propose to attach a rudder to guide it automatically. 


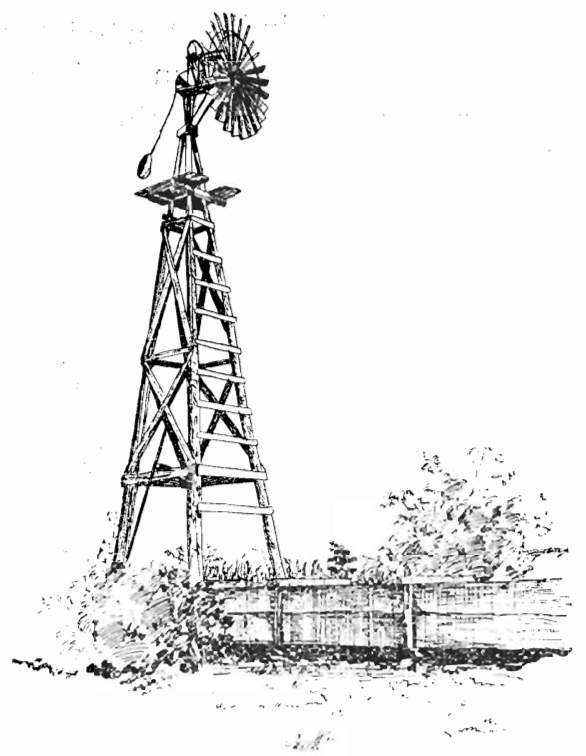

FIG. 65. The homemade steel windmill designed and built by Mr. W. F. Baldwi: Ainsworth, Nebraska, made largely of old machinery. Tower made of straight cottonwoc poles. The rudderlike regulator to the left sets the iron fans in or out of the wind, the regulating the mill to winds of varying velocities. Cost, $\$ 5$. For construction of fans st Fig. 66 .

\section{VANELESS TURBINES}

Almost any steel mill, in case of the loss of its rudder will ye swing around with its back to the wind instead of its face, an yet continue to run about as well as before, though backwards This fact is taken advantage of, and thus one mechanical part $i$ easily dispensed with, and greater simplicity secured, which $i$ the highest attainment in the art of inventing.

The vaneless mill of W.F. Baldwin, of Ainsworth, Brown Co when visited in the fall made a fine showing, as good as could $b$ expected of any first model. Eight similar models built for neigh bors were giving entire satisfaction and were better built. this same mill were built at the shop, and with the same car which is bestowed on the steel mill, it would scarcely find a st perior. Its arrangement for adjusting itself instantly to ever varying wind, whether a gust or zephyr, seemed very sensitiv and hardly to be improved upon. 


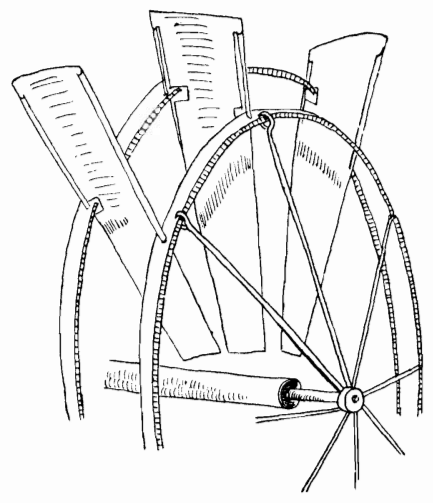

FIG. 66.

The idea which led to the invention is this; in the ordinary steel mill the fan is struck by the full force of a sudden gust before its mechanism begins to turn it out of the wind and so to adjust it. In the meantime it sustains the shock of the full wind. This led Mr. Baldwin to devise a method whereby the regulating lever should be struck by the blast first, and so throw the fans as to escape the full fury of the wind. He has attained this end in a very clever way. In Fig. 65 may be seen a regulator or rudder-like lever, in front of the fans. The slightest motion of the lever is instantly conveyed to the fans, which are turned edgewise more or less, according to the velocity of the wind, thus adjusting it with nicety. A little further examination will show a weight suspended to this lever which tends to keep the blades always in action. When the weight is removed the fans are exactly edge to the wind, so the mill is completely out of gear. Detailed drawings and the working parts will be shown at another time, and photographs of the mill and surroundings will be furnished as soon as space and means will allow.

It has been in use pumping water for the house and stock for three years past, and is yood for several years of service yet, and the whole mill cost but five dollars, which shows what a small water tax the man with the windmill has to pay, as compared with many a man in the city. 


\section{GIANT TURBINES}

In regions subject to high winds there is risk of mills on hig towers being overthrown, especially when the diameter of th wheel is increased above ten or twelve feet; so in order to ge breadth of base and corresponding stability, we find a mill whic is built inside of its tower instead of upon it. This is the re markable giant Turbine of $\mathrm{J}$. W. Warner, four and one ha! miles southeast of Overton.

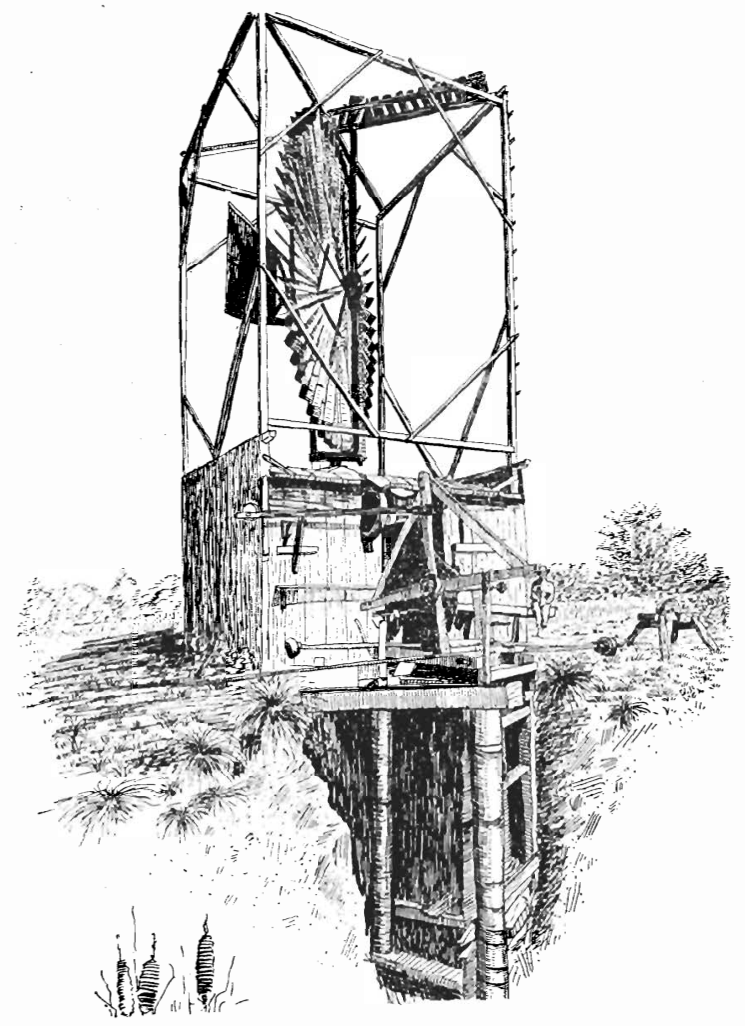

FIG. 67. Giant Turbine windmill designed and built by Mr. J. W. Warner, near Overto] Nebraska. Diameter twenty feet; runs a four horse power feed grinder, and other machir ery, and drives two pumps, one with a five-inch, the other with a four-inch cylinder; fou: teen inch stroke; eight foot lift. Irrigates ten acres of alfalfa, and six to eight acres: corn. Cost, $\$ 60$. 
This giant Turbine with its twenty foot wheel is the largest known as yet, and while its true efficiency could not at the time be measured, yet it runs a four horse power feed grinder, which is a practical measure of its strength. However it runs the grinder with less speed than the four horses. It is probably a two or three horse power mill. It also runs the grindstone and other machinery by means of overhead shafting with pulleys and belts. It is also connected to a walking beam and drives two large pumps with a thirteen-inch stroke; one pump having a four-inch, and the other a five-inch cylinder. The owner says they should have been six-inch cylinders.

As it stands it has irrigated eight to ten acres of alfalfa and six or eight acres of corn by pumping directly into the furrows. Mr. Warner believes that when a proper storage reservoir shall have been built, he can irrigate twenty acres sufficiently for that region, where good yields are assured without irrigation.

The expenses of this mill-an especially well built and painted one-amount to nearly one hundred dollars. But now that the owner's original ideas are put into material form, he could build the same mill in less time and at half the cost.

It is a splendid looking structure and has no equal in its class, although two other similar mills, built upon a somewhat similar but smaller plan, are known farther west, near Lexington. See Fig. 67 .

\section{MOCK TURBINES}

Our Mock Turbines so closely resemble the shopmade mills that they pass for them, and this is why they are so seldom noticed.

As an example we will select the mill of W. F. McComb, of Grand Island. The fans are of metal, the rudder of light wood, easily thrown in and out of gear. It lifts water forty-four feet and irrigates garden and lawn, and costs a possible twenty dollars, and has been in service since the spring of 1897 . 


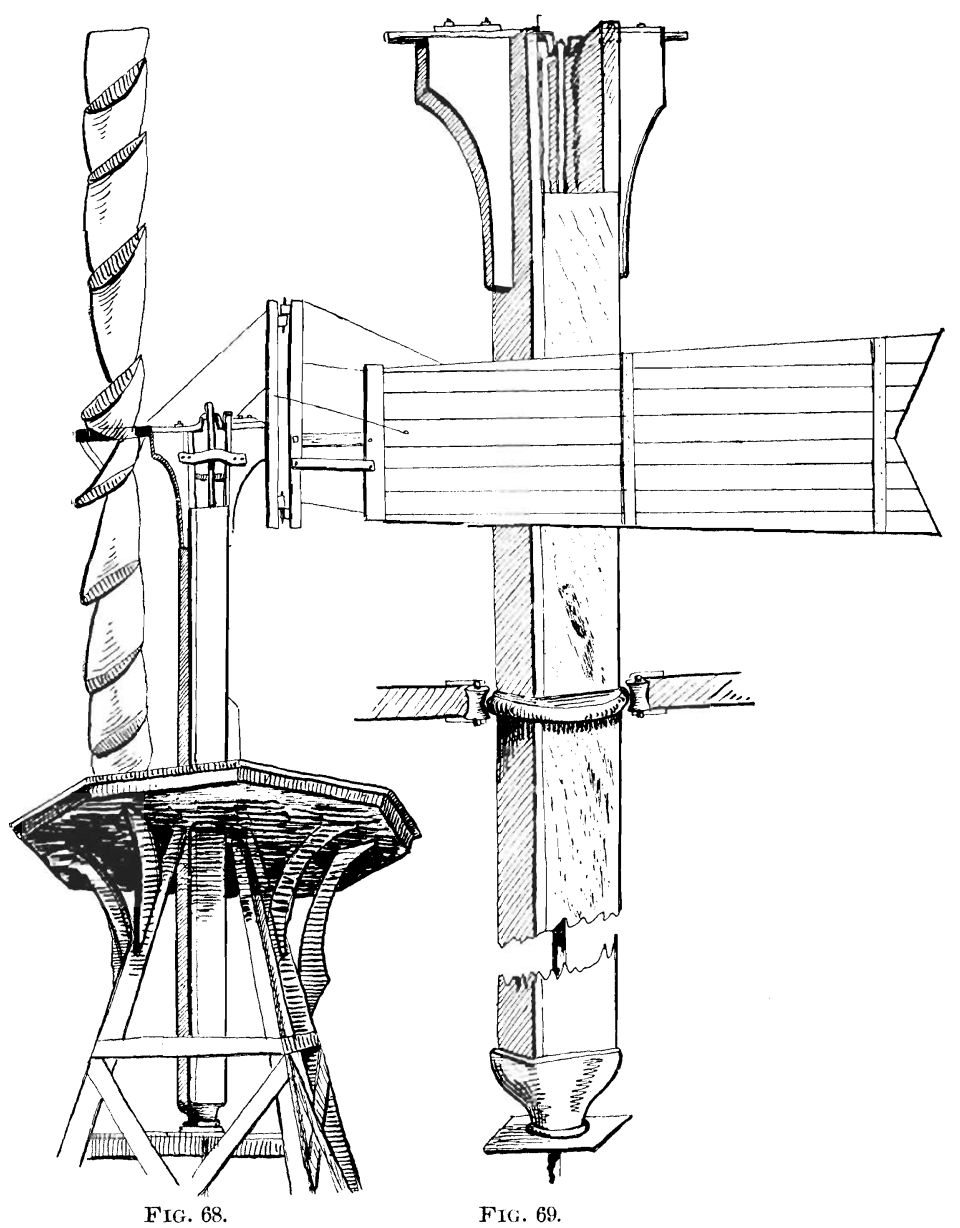

FIGs. 68 and 69. Showing the construction of the homemade Turbine mill built by Mr. W. F. McComb, Grand Island, Nebraska. This is often mistaken for a regular shopmade mill. Diameter ten feet. Cost about $\$ 20$.

Some of our Mock Turbines are made with less care, and some with greater, but all are quite like the shopmade article.

If anyone contemplates building so elaborate a mill, one which must consume time and money, and which comes dangerously close to the price of a regular one, he is advised to consider the practicability of patronizing his nearest windmill agent, or else to buy and repair some damaged mill. 


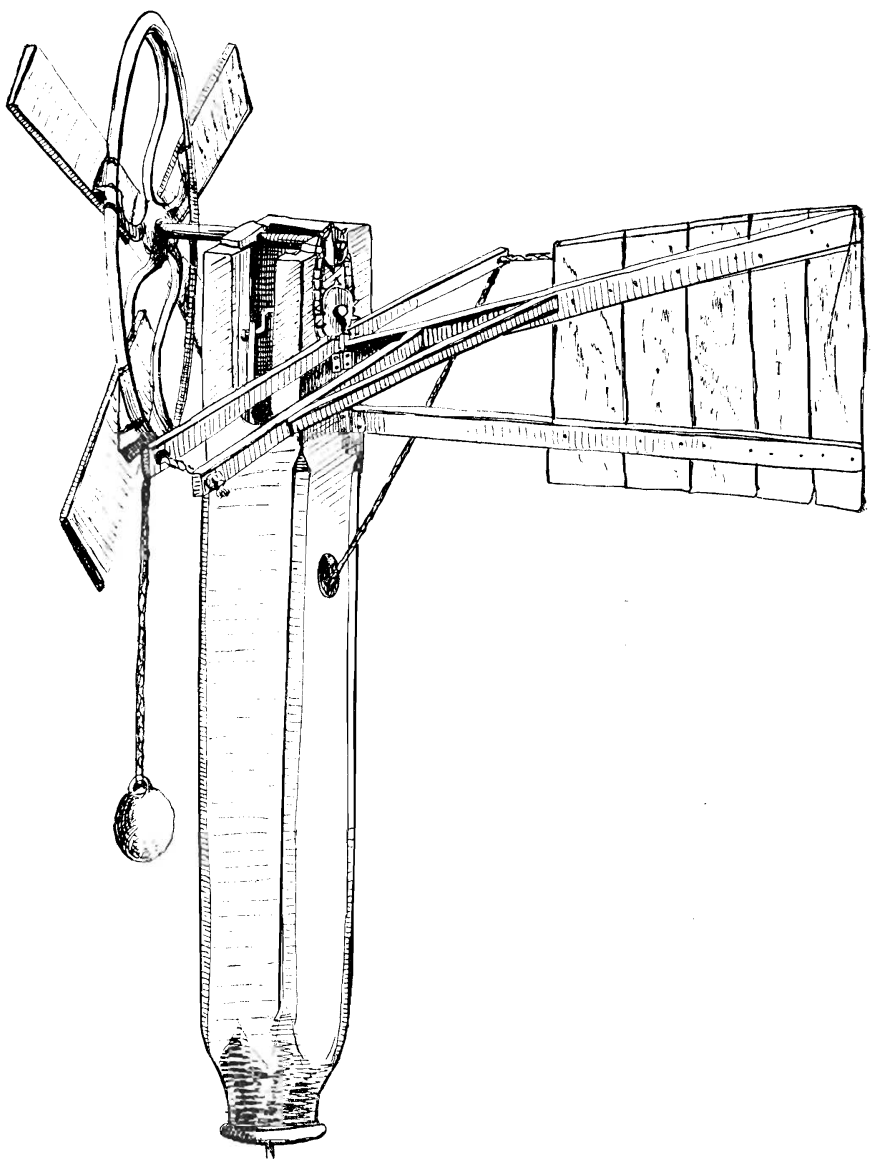

Fir; io. Construction of the four fan Turbine mill of Henry Boerson near Grand Island. The head of an old wooden pump serves as the axis on which the mill revolves. The driving parts consist of the fly wheel and sprocket wheels of an old corn sheller. The fans were wired to the spokes of the fly wheel. Geared in the ratio of three revolutions of the fans to two strokes of the pump. A crossbar nailed to the pump head carries two pullers (made of spools): a weighted piece of rope passing through one pulley, and attached to an arm on the rudder, tends to hold the rudder in position. A pull on the opposite rope, which passes down the center of the wooden pump head, throws the rudder to one side, and the mill out of gear. Eight foot wheel: pumps water for sixty head of cattle; Cost $\$ 2$. 


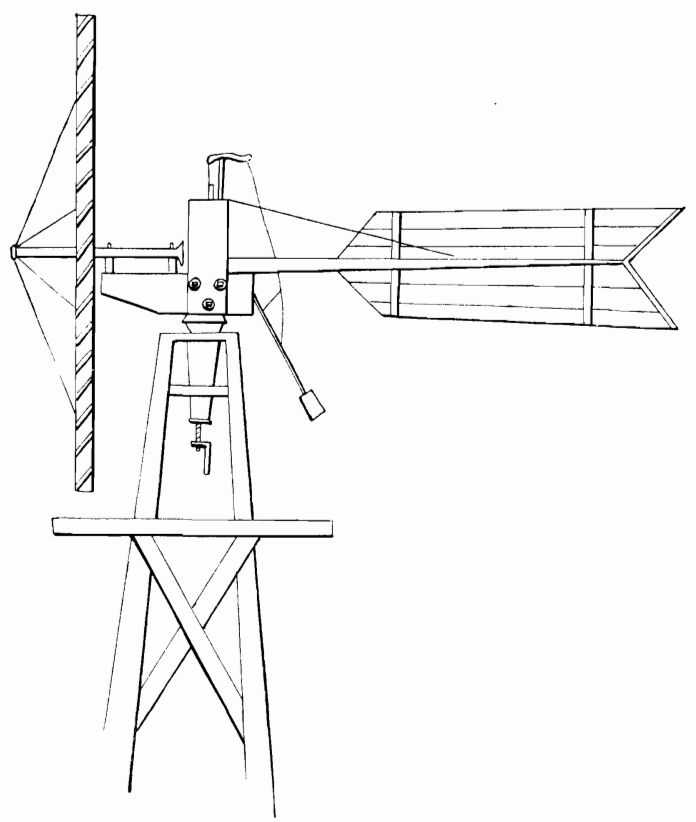

FIG. 71. A homemade Turbine windmill made by attaching rough board fans to driving wheel and crank of an old reaping machine. The swivel is the thimble of an wagon. Cost $\$ 6$. Pumps twelve hundred gallons a day, in ordinary winds.

\section{THE RECONSTRUCTION OF WINDMILLS}

These mills rank in importance next to the regular mill, a offer possibilities which many may avail themselves of to go advantage. There is scarcely a community without seve damaged and fallen mills, sometimes new, or but little wo Sometimes good mills and towers are overturned by a hea wind storm-we have found as many as fifty in the path of single storm-and there they lie to be grown over with wee At the busy season when such storms are most frequent, $m$ cannot afford to abandon the larger and more important work tending the growing crops, to put up a mill. For the man moderate means it is often better policy to send for the wir mill agent and order a new mill put up. But for the man of 1 , means, the fallen mill opens opportunities. He can now buy $t$ fallen mill of his neighbor at his own price. The essential pa 
will be damaged but slightly, and the other parts may be easily restored.

Judiciously managed, the cost of such reconstruction will not exceed that of a Jumbo or Battle-ax, and with better results.

Then again there is the mill which stands in disuse because of some accident to the fans, rudder, or other unessential and easily restored parts. Such mills may be purchased at small cost, and after a little repair, may be reinstated upon their towers, not quite as good as new, but almost as serviceable.

It is no new idea, but one put in practice in almost every town. We have traced them from Ogallala and intermediate points nearly to Omaha. At Ogallala, within the radius of a few blocks we found five reconstructed mills, all of them in use in some capacity; either pumping for the house, or watering the garden, trees and lawn, or the stock.

At the Ogallala livery barn an old mill was rejuvenated without cost, and at the expenditure of but little labor, and when visited was doing good service pumping water for twenty-five horses.

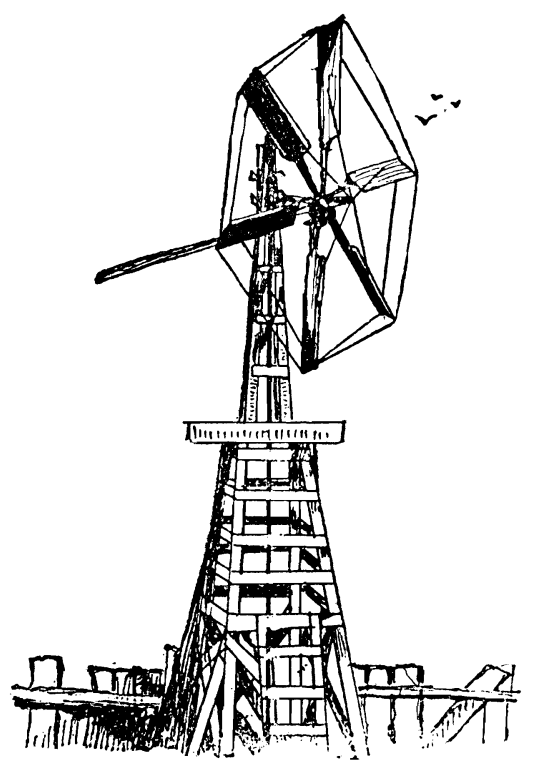

FIG. ซ2. 
The original fans had been broken off in a storm, likewise the rudder, but the six arms stood in position, and it only remained to fasten to them some sort of new fans. This was accomplished by nailing upon the bare arms six ordinary boards, set at an angle and bound together by strong fencing wire, as may be seen in Fig. 72.

Across the street and three blocks beyond was another mill, rather an elaborate affair as it stood upon its substantial tower, which formerly had supported a fine shopmade mill. After this mill had become a skeleton, with little left but bare arms, it was restored to life and usefulness by nailing on a few paddle shaped boards for fans. The original mill was used for watering a large garden and lawn, and for starting trees about the place. The rejuvenated mill was doing almost as much, and cost nothing.

At the edge of the town we saw a minature mill, a veritable toy, and yet when examined, it turned out to be the best of

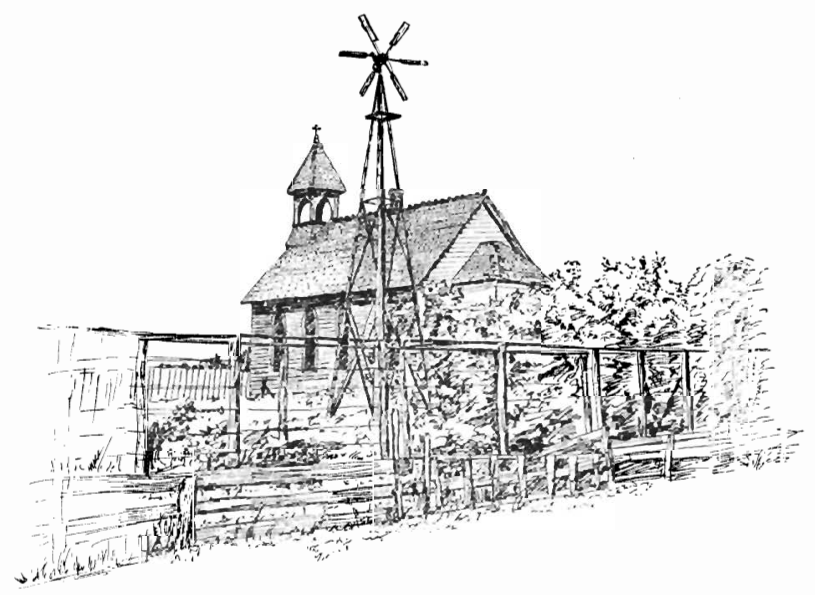

FIG. 73. The reconstructed Aermotor-a veritable toy-which cost nothing yet pumped water for the house, four head of horses, lawn, garden, and small fruit. By measurement it pumped, in a $15^{1 / 2}$-mile wind, 270 gallons in an hour, or at the rate of 6480 gallons in twentyfour hours: that is $\$ 1$ worth of water in a day according to the rate of .0015 cents a gallon, as charged in Lincoln. Wheel eight feet in diameter. Depth of well twelve feet. Property of A. C. Walker, civil engineer.

them all. It stood upon a tall, slender tower made of steel, and seemed but a plaything. It was an excellent Aermotor, which 
had twice lost rudder and fans in destructive gales, by throwing the rudder into the revolving fans. However, the working parts were not damaged, and the six steel arms stood in position. Half inch lumber from the sides of pine boxes constituted the fans, each of which was two feet long, and five inches wide, wired securely to the steel arms. Having no rudder the mill stood back, instead of face, to the wind, and of course ran in a reversed direction. But what did that matter?

It pumped for the house, for four head of horses, and for the irrigation of the lawn and trees, and the garden, and grape vines, and small fruit. We measured the wind velocity with an ane-

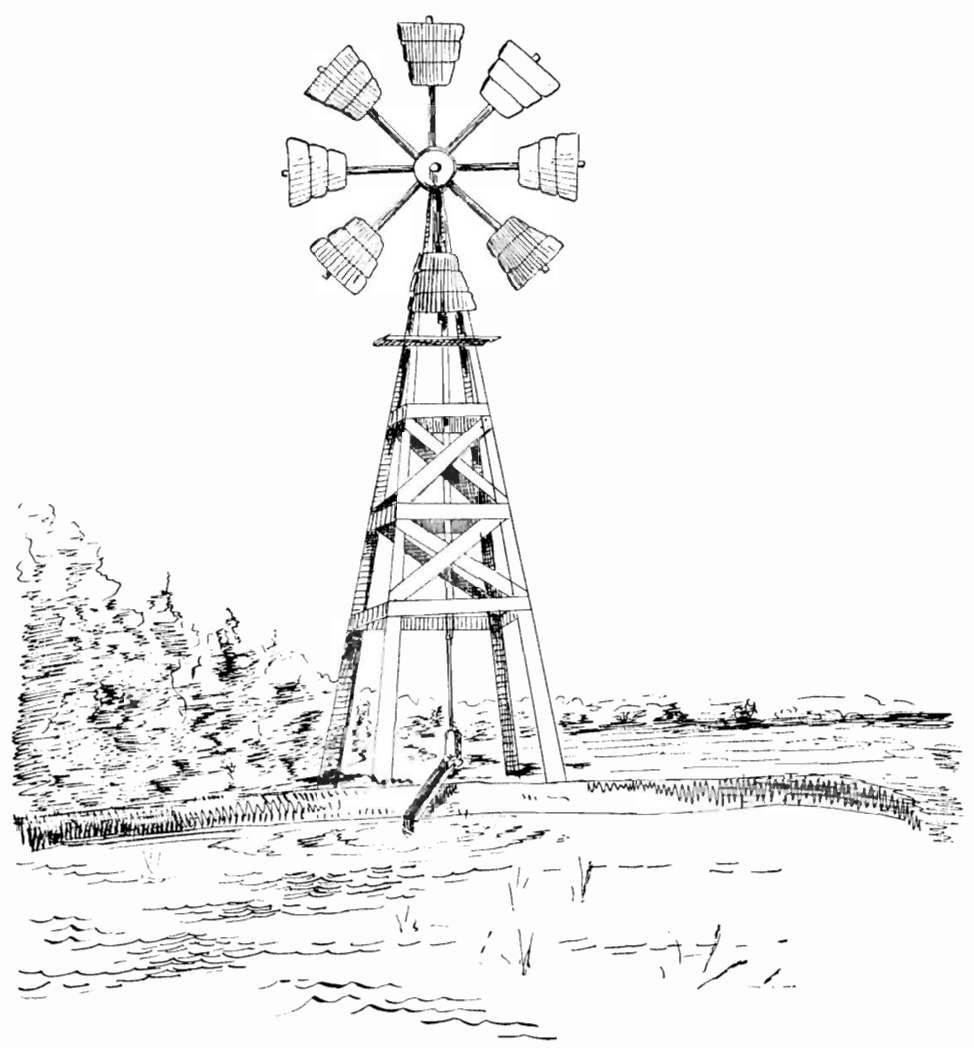

FIG. 74. A reconstructed windmill seen near Kearney, Nebraska. Thin lumber was nailed at the proper angle upon the somewhat lengthened and strengthened arms of an abandoned windmill. 
mometer, and measured the water pumped from a shallow well, (twelve feet deep). The wind was blowing at the rate of about fifteen and one-half miles per hour, and the pump was discharging a trifle more than two hundred and seventy gallons per hour. This too was built without cost.

At Kearney, we found a reconstructed mill and a storage reservoir, filled with water as in its better days. The arms had been lengthened a trifle, and at the extremities of each, three thin boards from the sides of boxes had been nailed. It was a crude affair, but that matters little when we know that it did its work well. Omitting numerous others, we must not fail to mention particularly the reconstructed mill of Elmer Jasperson, near Ashland, Saunders county. There are other examples just as creditable, but this is the last piece of work that has come under

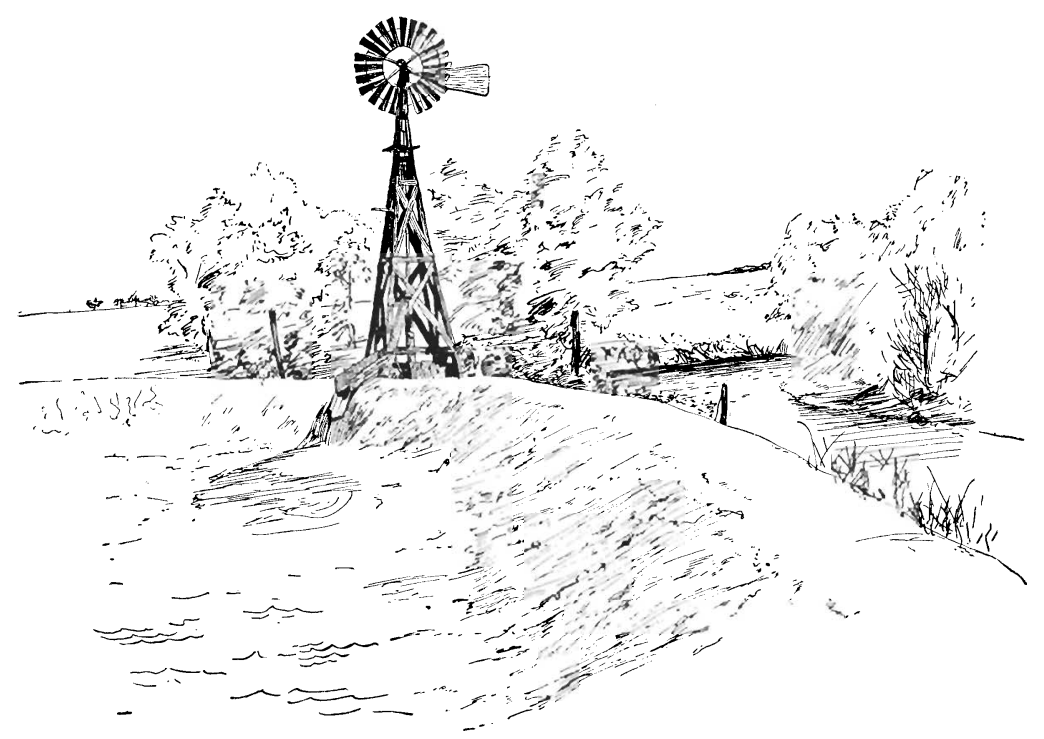

FIG. 75. The reconstructed windmill of Mr. Elmer Jasperson, Ashland, Nebraska. Fallen steel mill purchased for $\$ 3$; new tower built for $\$ 7$; mill reinstated as good as new at a total cost of $\$ 10$.

our personal observation. You could not distinguish this admirably constructed mill from a new, shopmade, steel mill, and yet upon climbing its tower, you could find where dents in the steel 
blades had been pounded out, and where bent and twisted rods and braces had been straightened.

On learning its history we found that a nearly new mill had been overturned and its steel tower rather helplessly wrecked. This was purchased as it lay for three dollars, and was hauled to the Jasperson place and set upon a new wooden tower which cost seven dollars. At a total outlay then of ten dollars, an eight foot wheel was secured, which looked as well and worked as well as a new mill costing several times that sum.

The first windmill erected in Stromsburg (an old style Stover) was blown down after three or four years of service. It was purchased for $\$ 5.00$ as it lay, by the Hon. Charles H. Morrill, of Lincoln, repaired and set up on his model farm at Stromsburg, where it did constant duty for fifteen years.

The matter of reconstructing and reclaiming abandoned, damaged and fallen mills offers many possibilities and the writer would cali the especial attention of farmers and others to the advantages which may be secured in this way.

\section{THE SHOPMADE MILL}

The shopmade mill is not the homemade mill, it is true, and yet they grade so insensibly into one another as to be all but inseparable, and they are such prominent features of every landscape that it is germane to the subject perhaps to introduce them in this connection.

In the great plains the windmill has come to be an essential feature of every landscape. One may easily count twenty-five to thirty mills from a single point of view, and in almost any town there will be forty or fifty in sight. Small towns have their water tanks, hydrants, and water systems, and it is the windmill which makes it possible for the resident of the town, or the farm and ranch to enjoy one of the luxuries and conveniences of the city home. Such water service is cheap and satisfactory.

Where the town is small, and a standpipe cannot be built they simply put up a very large tank, and a large mill. Above this 
they often erect a second tank in order to get increased pressure in the emergency of fire. Often the mill is augmented by a steam or gasoline engine for use in case of a dead calm.

But if one can turn the waste energy of the wind to account it is wiser and more economic. The first cost of a mill is not great and after its installation the cost of its maintenance is trifling.

Our water troughs, our rural cemeteries, homes, and asylums often depend upon the mill. The wind should be looked upon as a natural resource just as worthy of development as other natural resources. If we can derive our energy from the wind, why is it not as good as to get it from coal?

It is possible to store the wind in various ways, and here is a fruitful and promising field. This may be done by allowing the mill to run an air compressor. Already tanks filled with compressed air are used in a variety of ways in Europe and America, and much is to be made of it in the near future.

Some use the mill by day to charge a storage battery, and then draw off the stored up energy in the form of electricity to be used for lighting the house, or for running light machinery. There are possibilities here which are to be reported upon at some future time.

Sometimes a stream of compressed air if admitted at the bottom of a weak artesian well which comes close to the surface but does not flow, will produce a gushing artesian flow. Under its influence a tubular well often acts like an artesian well.

As it now stands the windmill is an achievement. It is scientifically planned and well made mechanically, and future experimental tests are sure to develop fresh uses and applications of its power, and through its medium, the wind which is going to waste, may minister to our comfort in a great variety of ways. 


\section{TR ANSMISSION OF WINDMILL ENERGY}

Sometimes our farmers find the well so situated that the windmill and tower cannot be set up without interfering with the porch, kitchen, and milkhouse; in which event, a walking beam, or rocker shaft often connects the mill and pump. If too distant, recourse is had to the angle block and connecting wires. In this way the mill at the house can be geared to run the pump at the barn, or even in a neighboring field.

The better way is to purchase such things of the man whose business it is to make them, and so have undivided time for one's own business. But when one wishes to make his own angles it is a simple matter, and several sketches are appended to suggest what may be done in transmitting the energy of the mill by means of two oscillating wires and a couple of quadrants cut out of a board.

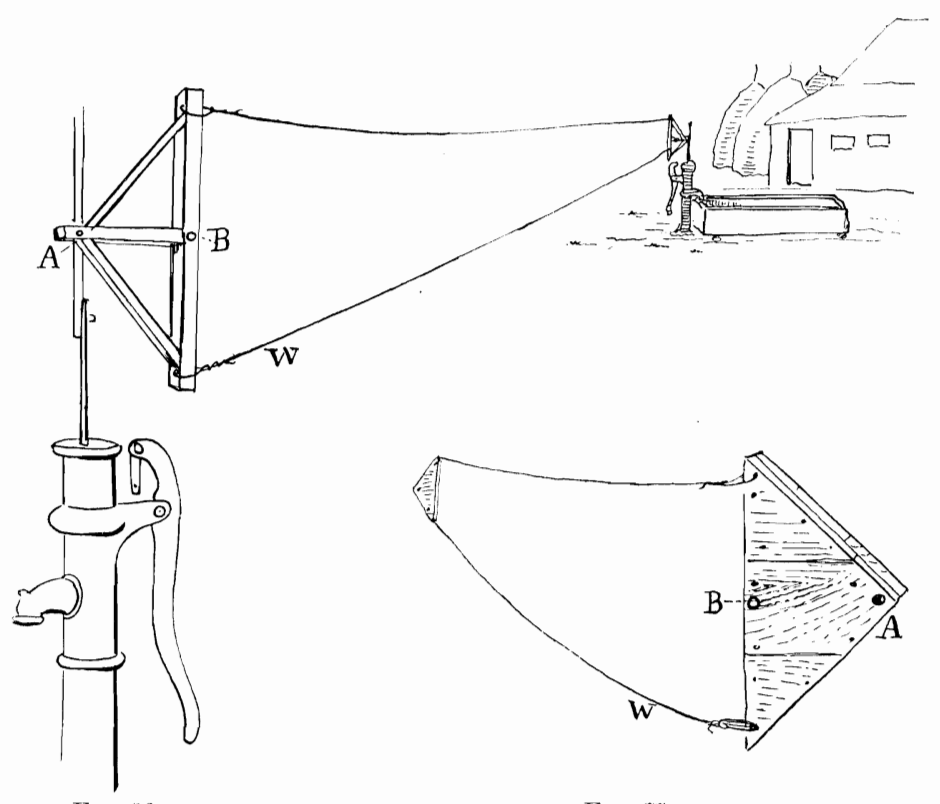

FIG. 77.

Figs. 76. To show how windmill energy may be transmitted from one point to another by means of home made quadrants and oscillating wires. Fig. $r$, a still simpler form. made of boards nailed together cross grained. A, attachment to pump rod; B. attachment to tower or stationary support; W, strong fencing wire. 


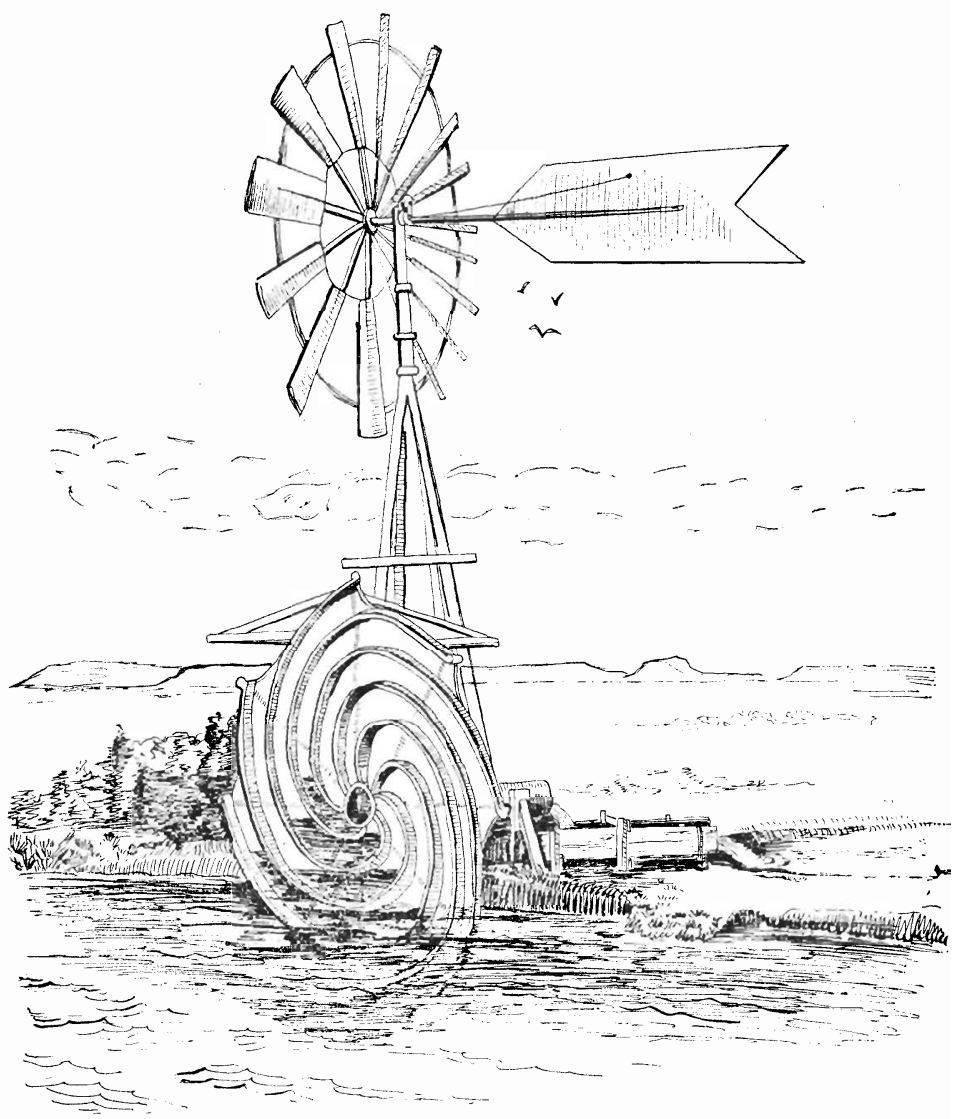

Fig. 78. A twelve-foot Aermotor windmill attached to a twelve-foot water wheel ot tympanum variety, designed and built by Mr. Thomas, North Platte, Nebraska. 
Miscelluneous Pupers by the Writer Concerning the Homemade Mills of Nebraska.

I.

THE HOMEMADE WINDMILLS OF NEBRASKA.

.The Nebraska Irrigation Annual, 1897, pp. 74 to 80.

II.

WESTERN HOMEMADE WINDMILLS.

Types of the poor man's mill. Farm Implement News, July, 1897.

III.

THE NEBRASKA “GO-DEVIL” WINDMILL.

Rural New Yorker, August 28, 1897.

IV.

ADDITIONAL NOTES OF THE HOMEMADE MILLS OF NEBRASKA.

Farm Implement News, January 12, 1897.

V.

A PRELIMINARY REPORT ON THE HOMEMADE WINDMILLS AND OTHER WATER LIFTERS OF NEBRASKA.

U. S. Hydrographic Survey, August, 1898. 